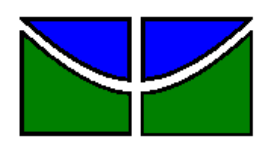

Universidade de Brasília

Faculdade de Economia, Administração e Contabilidade

Programa de Pós-Graduação em Economia

Mestrado Profissional em Economia

Dinuarí da Rocha Souza

\title{
Endividamento do Servidor Público: \\ uma análise econômica da situação na UnB
}

Brasília - DF 


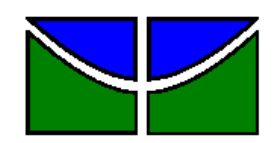

Dinuarí da Rocha Souza

\section{Endividamento do Servidor Público: uma análise econômica da situação na UnB}

Dissertação apresentada à Faculdade de Economia, Administração e Contabilidade, Programa de Pós-Graduação em Economia, como requisito parcial para a obtenção do título de Mestre em Economia, área de concentração: Gestão Econômica de Finanças Públicas sob Orientação do Professor Dr. Jorge Madeira Nogueira.

\section{COMISSÃO EXAMINADORA}

Prof. Dr. Jorge Madeira Nogueira (Orientador)

Prof. Dr. André Luiz Marques Serrano

Prof. Dr. Antonio Nascimento Junior

Brasília - DF, 26 de maio de 2015. 
Ficha catalográfica elaborada automaticamente, com os dados fornecidos pelo(a) autor(a)

S719e

Souza, Dinuarí da Rocha

Endividamento do Servidor Público: uma análise econômica da situação na UnB / Dinuarí da Rocha Souza; orientador Jorge Madeira Nogueira. -- Brasília, 2015. $87 \mathrm{p}$.

Dissertação (Mestrado - Mestrado em Economia) -Universidade de Brasília, 2015.

1. Endividamento Pessoal. 2. Análise Econômica. 3. Crédito Consignado. I. Nogueira, Jorge Madeira, orient. II. Título. 


\section{Agradecimentos}

Deus, obrigado por ter permitido a materialização desses pensamentos e a consecução dos meus objetivos.

Algumas pessoas tiveram participação direta para a elaboração deste trabalho, sendo essenciais em momentos de estimulo, motivação, ajuda, enfim, instantes de muita importância. Outras foram indispensáveis, mesmo tendo ajudado indiretamente. Cito, a seguir, algumas com participações mais atuantes.

Aos meus filhos, Dael Pitter, Denovan, Thaíssa Inês e Jefferson. Ao meu genro, Olean do Nascimento, minha nora, Roseane. Aos meus netos, Eduarda, Josué, Andressa e Larissa, pessoas que amo e com quem aprendo sempre mais do que ensino e que tornam minhas conquistas e atividades diárias mais simples e prazerosas.

À Ana Lucia, companheira de todas as horas, boas e ruins, por compreender a necessidade e a importância de algumas coisas para mim.

À família Souza, meus pais, Dinuamarques, 84 anos e Inês (in memóriam) - que me ampara e apoia - e a família Cunha - sempre junto a mim.

Manifesto minha gratidão ao Professor Doutor Jorge Madeira Nogueira - por quem cultivo grande admiração -, não somente por ter aceitado participar de minha formação acadêmica na condição de orientador mesmo diante de suas inúmeras tarefas, mas pela amizade conquistada como colega de profissão (docente / técnico-administrativo) que é exemplo a ser seguido pelos docentes, instigando os alunos mediante o seu espírito provocador, motivador e inquieto, essencial ao ambiente acadêmico.

Aos Professores do curso de Mestrado em Gestão Econômica de Finanças Públicas da Universidade de Brasília - Departamento de Economia, pela dedicação e empenho ao ensinar e promover o aprendizado das disciplinas que fizeram parte do curso e que muito auxiliaram no momento de elaboração deste trabalho.

Aos colegas da SAA/UnB, sempre atuantes em meu cotidiano de trabalho, pela paciência e pelo apoio direto. Cito os colegas do Serviço de Registro e Pós-Graduação / SAA: Lucimar, Milena, Fabiano, Ricardo, Severino, Thelmo e as estagiárias Ana Priscila e Lais. Cito especialmente a atenção fundamental e a valiosa contribuição de Francisco Timbó Ronélia Souza, Thaíssa Inês e Milena.

Agradeço à amizade dos meus colegas de disciplina do Mestrado, pois partilhamos um convívio saudável e de constante desenvolvimento e aprendizado mútuo recheado de respeito, estímulo, confiança e companheirismo. 
Aos servidores do Mestrado em Economia - Gestão Econômica de Finanças Públicas Departamento de Economia da Universidade de Brasília pela cordialidade e presteza no atendimento durante todo o período de realização do curso, em especial, Waneska e Joana. 
"Os objetos foram feitos para serem usados. As pessoas foram feitas para serem amadas. O mundo vai mal porque se usam as pessoas e se amam os objetos."

Paraclitus

“Aprenda a viver dentro das suas possibilidades. Buscar uma vida de aparências, fora da sua realidade, só leva para um abismo sem volta. Construa a sua vida e extraindo da vida o que tem de melhor: A SIMPLICIDADE."

Chico Xavier.

"Ame o que faz e o dinheiro surgirá."

Lair Ribeiro. 


\title{
RESUMO
}

Este trabalho tem por objetivo analisar o endividamento do Servidor Público Federal da Fundação Universidade de Brasília (FUB). Esse endividamento tem se caracterizado pela ampliação da oferta de crédito a pessoas físicas no Brasil, por meio do empréstimo consignado. A dissertação se desenvolve da seguinte forma: inicialmente, apresenta-se o quadro teórico que serviu de referência para a realização do presente estudo, a saber, economia do endividamento e empréstimo consignado, apresentando os conceitos básicos de endividamento pessoal, a oferta de crédito e endividamento, a demanda por crédito e endividamento, a conjuntura econômica e endividamento, o endividamento recente do brasileiro: uma visão geral, o acesso amplo do brasileiro ao crédito, o comportamento de endividamento pessoal entre 2000 e 2014 e o quadro de endividamento por região. Em seguida, é apresentada a amostra metodológica da pesquisa, predominantemente composta por relatórios sobre os empréstimos consignados aos servidores da FUB. Os servidores que são docentes dividem-se por classe, e os que são técnicos administrativos, por nível de escolaridade. Os resultados indicaram que o crédito consignado, apesar de ser a modalidade com as taxas de juros menores no mercado, com a facilidade de obtenção de crédito que não necessita de apresentação de fiador, tem levado servidores ao endividamento financeiro pessoal e familiar. No geral em 2013 60,80\% dos servidores técnicos administrativos assumiram dívidas do crédito consignado, enquanto a classe dos docentes apenas $32,09 \%$. Já em 2014 56,64 dos servidores técnicos administrativos e 30,28\% dos docentes estavam com dívidas do crédito consignado.

Palavras-chave: Endividamento Pessoal, Análise Econômica, Crédito Consignado.

\begin{abstract}
This work has for objective to analyse the indebtedness of Federal public servant of the Fundação Universidade de Brasília (FUB). This indebtedness has been characterized by the expansion of the supply of credit to individuals in Brazil, by means of a secured loan. The dissertation is organized as follows: initially, it presents the theoretical framework that served as a reference for the conduct of this study, namely, economy of indebtedness and payroll loans, introducing the basic concepts of personal indebtedness, indebtedness and credit supply, the demand for credit and indebtedness, the general economic and debt, recent Brazilian debt: an overview, the broad access of Brazilian credit, personal indebtedness behavior between 2000 and 2014 and the painting of indebtedness by region. Then presented the methodological research sample, predominantly composed of reports about the loans to the servers of the FUB. The servers are divided by class teachers, and those that are administrative technicians, by level of education. The results indicated that the payroll loans, despite being the mode with lower interest rates in the market, with the ease of obtaining credit that does not require submission of guarantor, has led to the servers personal and family financial indebtedness. Overall in $201360.80 \%$ of the administrative technical servers assumed debt of payroll loans, while class teachers only $32.09 \%$. As early as 201456.64 administrative and technical servers $30.28 \%$ of the teachers were with debts of payroll loans .
\end{abstract}

Keywords: Personal Debt, Economic Analysis, Payroll Loans. 


\section{LISTA DE QUADROS}

Quadro 1.1 Origens das dívidas pessoais e familiares................................................21

Quadro 1.2 Modalidade de crédito pessoal física..........................................................22

Quadro 1.3 Processo de crédito do Banco do Brasil........................................................23

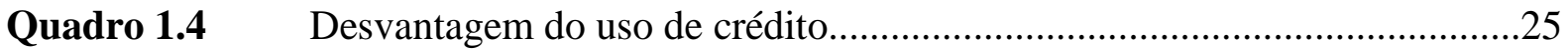

Quadro 1.5 Princípios e recomendações de educação financeira.....................................30 


\section{LISTA DE TABELAS}

Tabela 2.1 Participação em \% nos valores das operações de crédito do SFN - por setor, $2000-2014$ .34

Tabela 2.2 Papel-moeda em circulação do público - Dez 2012 / Fev 2014. .35

Tabela 2.3 Evolução geral do crédito - 2010 a 2012. .38

Tabela 2.4 Evolução do crédito a pessoas físicas - Saldos - 2010 a $2012 .$. .39

Tabela 2.5 Percentual das principais dívidas das famílias - 2014 . .40

Tabela 2.6 Síntese dos resultados - médias por região em 2013 .46

Tabela 2.7 Nível de endividamento - dezembro de 2013. 47

Tabela 2.8 Tipo de dívida - dezembro de 2013 48

Tabela 2.9 Parcela da Renda comprometida com dívida (dentre os endividados dezembro de 2013. .48

Tabela 3.1 Quantidade de servidores técnicos da FUB das folhas de pagamento dos meses de janeiro e dezembro dos anos de 2013 e 2014 por classe. .55

Tabela 3.2 Quantidade de servidores docentes da FUB das folhas de pagamento dos meses de janeiro e dezembro dos anos de 2013 e 2014 por classe. .56

Tabela 3.3 Quantidade de servidores técnicos da FUB e valor total dos vencimentos constantes das folhas de pagamento do mês de dezembro de 2013 e de 2014. Divididos por classes. Valores em reais correntes. .57

Tabela 3.4 Quantidade de servidores docentes da FUB e valor total dos vencimentos constantes das folhas de pagamento do mês de dezembro de 2013 e de 2014. Divididos por classes. Valores em reais correntes. .58 
Tabela 3.5 Montante de empréstimo concedido aos servidores técnico-administrativos (ativos e inativos) em 2013 e 2014, divididos por classe e variação \% $2013 / 2014$

Tabela 3.6 Montante de empréstimo concedido aos servidores docentes (ativos e inativos) em 2013 e 2014, divididos por classe e variação \% 2013/2014...63

Tabela 3.7 Quantidade de servidores técnicos da FUB em dezembro de 2013, quantidade de técnicos que possuíam empréstimo consignado com desconto em folha no ano 2013 e o percentual em relação ao total geral, por classe.

Tabela 3.8 Quantidade de servidores técnicos da FUB em dezembro de 2014, quantidade de técnicos que possuíam empréstimo consignado com desconto em folha no ano 2014 e o percentual em relação ao total geral, por classe .65

Tabela 3.9 Quantidade de servidores docentes da FUB em dezembro de 2013, quantidade de docentes que possuíam empréstimo consignado no ano 2013 e o percentual em relação ao total geral, por classe

Tabela 3.10 Quantidade de servidores docentes da FUB em dezembro de 2014, quantidade de docentes que possuíam empréstimo consignado no ano 2014 e o percentual em relação ao total geral, por classe .67

Tabela 3.11 Montante de empréstimo concedido em reais corrente aos servidores técnico-administrativos (ativos e inativos) em 2013 e 2014, e o respectivo percentual, por classe.

Tabela 3.12 Montante de empréstimo concedido em reais corrente aos servidores docentes (ativos e inativos) em 2013 e 2014, e o respectivo percentual por classe.

Tabela 3.13 Número de Funcionários Públicos - FUB................................................73

Tabela 3.14 Valor da Folha de Pagamento - FUB .....................................................

Tabela 3.15 Número de Funcionário / Números de Empréstimos 2013/2014 .74 
Tabela 3.16

Montante Empréstimo Consignado 2013/2014.

.75 


\section{LISTA DE GRÁFICOS}

Gráfico 3.1 Quantidade de servidores técnicos da FUB da folha de pagamento do mês de janeiro de 2013 por classe.

Gráfico 3.2 0Quantidade de servidores técnicos da FUB da folha de pagamento do mês de dezembro de 2013 por classe. .51

Gráfico 3.3 Quantidade de servidores técnicos da FUB da folha de pagamento do mês de janeiro de 2014 por classe. .52

Gráfico 3.4 Quantidade de servidores técnicos da FUB da folha de pagamento do mês de dezembro 2014 por classe

Gráfico 3.5 Quantidade de servidores docentes da FUB da folha de pagamento do mês de janeiro de 2013 por classe. .53

Gráfico 3.6 Quantidade de servidores docentes da FUB da folha de pagamento do mês de dezembro de 2013 por classe. .54

Gráfico 3.7 Quantidade de servidores docentes da FUB da folha de pagamento do mês de janeiro de 2014 por classe. .54

Gráfico 3.8 Quantidade de servidores docentes da FUB da folha de pagamento do mês de dezembro de 2014 por classe. .55

Gráfico 3.9 Montantes das folhas de pagamento dos servidores técnicos da FUB do mês de dezembro dos anos de 2013 e 2014 .57

Gráfico 3.10 Montantes das folhas de pagamento dos servidores docentes da FUB do mês de dezembro dos anos de 2013 e 2014.

Gráfico 3.11 Montantes das folhas de pagamento dos servidores técnicos da FUB do mês de dezembro de 2013 e o montante de empréstimo consignado de 2013 por classe . .60 
Gráfico 3.12 Montantes das folhas de pagamento dos servidores técnicos da FUB do mês de dezembro de 2014 e o montante de empréstimo consignado de 2014 por classe.

Gráfico 3.13 Montantes das folhas de pagamento dos servidores docentes da FUB do mês de dezembro de 2013 e o montante de empréstimo consignado de 2013 por classe.

Gráfico 3.14 Montantes das folhas de pagamento dos servidores docentes da FUB do mês de dezembro de 2014 e o montante de empréstimo consignado de 2014 por classe.

Gráfico 3.15 Quantidade de servidores técnicos da FUB que em 2013 possuíam prestações a pagar de empréstimo consignado, por classe e seus respectivos percentuais .66

Gráfico 3.16 Montantes de empréstimo concedidos aos servidores técnicos da FUB em 2013 por classe e seus respectivos percentuais. .66

Gráfico 3.17 Quantidade de servidores docentes da FUB que em 2013 possuíam prestações a pagar de empréstimo consignado, por classe e seus respectivos percentuais. .68

Gráfico 3.18 Montantes de empréstimo concedidos aos servidores docentes da FUB em 2013 por classe e seus respectivos percentuais.

Gráfico 3.19 Quantidade de servidores técnicos da FUB que em 2014 possuíam prestações a pagar de empréstimo consignado, por classe e seus respectivos percentuais .70

Gráfico 3.20 Montantes de empréstimo concedidos aos servidores técnicos da FUB em 2014 por classe e seus respectivos percentuais. .70

Gráfico 3.21 Quantidade de servidores docentes da FUB que em 2014 possuíam prestações a pagar de empréstimo consignado, por classe e seus respectivos percentuais. 
Gráfico 3.22 Montantes de empréstimo concedidos aos servidores docentes da FUB em 2014 por classe e seus respectivos percentuais............................................72 


\section{LISTA DE ABREVIAÇÕES E SIGLAS}

\begin{tabular}{|c|c|}
\hline BCB & Banco Central do Brasil \\
\hline BNDES & Banco Nacional de Desenvolvimento Econômico e Social \\
\hline CET & Custo Efetivo Total \\
\hline CLT & Consolidação das Leis do Trabalho \\
\hline $\mathrm{CNC}$ & Confederação Nacional do Comércio de Bens, Serviços e Turismo \\
\hline DGP & Decanato de Gestão de Pessoas \\
\hline FECOMÉRCIO SP & Federação do Comércio de São Paulo \\
\hline FUB & Fundação Universidade de Brasília \\
\hline IBGE & Instituto Brasileiro de Geografia e Estatística \\
\hline IEF & Índice de Expectativa das Famílias \\
\hline IETS & Instituto de Estudos do Trabalho e Sociedade \\
\hline IFES & Instituição Federal de Ensino Superior \\
\hline IFs & Instituições Financeiras \\
\hline IPCA & Índice de Preços ao Consumidor Amplo \\
\hline IPEA & Instituto de Pesquisa Econômica Aplicada \\
\hline IPTU & Imposto Predial e Territorial Urbano \\
\hline IPVA & Imposto sobre a Propriedade de Veículos Automotores \\
\hline MP & Ministério Público \\
\hline $\mathbf{O A B}$ & Ordem dos Advogados do Brasil \\
\hline PEIC & Pesquisa Nacional de Endividamento e Inadimplência do Consumidor \\
\hline POF & Pesquisa de Orçamentos Familiares \\
\hline SERASA & Centralização dos Serviços dos Bancos \\
\hline SPC & Serviço de Proteção ao Crédito \\
\hline STJ & Superior Tribunal de Justiça \\
\hline TCU & Tribunal de Contas da União \\
\hline UFRJ & Universidade Federal do Rio de Janeiro \\
\hline
\end{tabular}




\section{SUMÁRIO}

INTRODUÇÃO

1 ECONOMIA DO ENDIVIDAMENTO

1.1 Conceitos Básicos de Endividamento Pessoal 19

1.2 Oferta de Crédito e Endividamento 20

1.3 Demanda por Crédito e Endividamento 24

1.4 Conjuntura Econômica e Endividamento 25

1.5 Educação Financeira: sua ausência com causa de endividamento? 28

2 O ENDIVIDAMENTO RECENTE DO BRASILEIRO: UMA VISÃO GERAL 33

$2.1 \mathrm{O}$ acesso amplo do brasileiro ao crédito 33

2.2 Comportamento do endividamento pessoal entre 2000 e 2014

2.3 Endividamento por categoria profissional 41

2.3.1 Servidores Privados e em Geral 41

2.3.2 Servidores Públicos $\quad 41$

2.4 Endividamento por região $\quad 45$

3 O ENDIVIDAMENTO DO SERVIDOR PÚBLICO DA UnB 50

3.1 À guisa de introdução $\quad 50$

3.2 Características Gerais da Amostra $\quad 50$

3.3 Panorama geral do endividamento do servidor da FUB 56

$\begin{array}{ll}3.4 \text { Resumo dos Principais resultados } & 73\end{array}$

$\begin{array}{ll}\text { CONCLUSÃOO } & 76\end{array}$

REFERÊNCIAS BIBLIOGRÁFICAS

$\begin{array}{lr}\text { ANEXOS } & 83\end{array}$ 


\section{INTRODUÇÃO}

Endividamento pode surgir na vida de qualquer indivíduo. Toda dívida tem sua causa; na verdade, "suas causas", pois em geral é uma combinação de fatores que levam uma pessoa a ficar endividada. As consequências do endividamento também são relevantes. A administração ineficiente do dinheiro deixa os consumidores vulneráveis a crises financeiras mais graves. Na verdade, dependendo do número de indivíduos endividados em uma comunidade, as operações de mercado e as forças competitivas podem ficar comprometidas por causa da inabilidade dos consumidores em administrar efetivamente suas finanças.

De acordo com Marques e Frade (2003), o endividamento é o saldo devedor de um agregado, o que significa dizer que endividamento é a utilização de recursos de terceiros para fins de consumo ou de investimento. Ao se apossar desse recurso se estabelece um compromisso em devolver, com a data estabelecida, tal montante, normalmente acrescido de juros. O endividamento pode ser acompanhado pelo descumprimento do compromisso assumido com outrem, surgindo assim a inadimplência, ou seja, o não pagamento pontual dos compromissos financeiros por parte do devedor. A situação mais grave que pode decorrer do endividamento é o sobre-endividamento, também designado por falência ou insolvência, que consiste nos casos em que o devedor está completamente impossibilitado, de forma duradoura ou estrutural, de pagar uma ou mais dívidas (MARQUES e FRADE, 2003).

No caso específico do Brasil, o crescimento econômico aliado à estabilidade monetária experimentada nos últimos vinte anos, evidencia formas distintas de se lidar com o dinheiro. Os brasileiros que antes eram obrigados a consumir tudo que ganhavam para não perderem a capacidade de compra, reduzida constantemente devido à alta inflação, tiveram de mudar seus hábitos de gestão do dinheiro, pois se experimentou um considerável aumento da oferta de crédito, nos últimos anos. Por diversas possíveis razões ${ }^{1}$ - que serão aprofundadas na sequência do texto - tem havido o aumento concomitante do endividamento de pessoas físicas brasileiras.

Entre essas pessoas físicas uma merece destaque em relação ao incremento do seu acesso ao crédito e ao consequente endividamento: o servidor público federal. Para auxiliar no controle das finanças pessoais dos empregados e servidores da Administração Pública, foi aprovada a Medida Provisória n. ${ }^{\circ}$ 130, de 17 de setembro de 2003, publicada no Diário

\footnotetext{
${ }^{1}$ Crises econômicas nacionais e internacionais, despesas sazonais, marketing sedutor, orçamento deficitário, perda de emprego ou parte da renda familiar, defeito ou batida do veículo, problemas de saúde na família, separação de bens não dos gastos (divórcio) e o analfabetismo financeiro.
} 
Oficial da União, de 18 de setembro de 2003, convertida na Lei n. ${ }^{\circ} 10.820$ pelo Presidente da República. Essa Lei passou a autorizar o desconto em folha dos valores referentes a pagamento de empréstimos e estabeleceu o limite de até $30 \%$ da remuneração disponível ${ }^{2}$ para esse desconto.

A facilidade de obtenção de créditos, em que o servidor público se apresenta a um caixa eletrônico do banco pelo qual seu salário é depositado em sua conta corrente ou em operações simples pelo internet banking, tem levado esse servidor a um nível de endividamento e à inadimplência, comprometendo, entre outros aspectos, sua renda, sua produtividade e seu bem estar. Neste momento da dissertação essa afirmação de endividamento crescente do servidor público brasileiro é apenas uma "hipótese de trabalho", que poderia ser detalhada para: o advento do crédito consignado colocou o servidor público federal como um dos principais componentes da categoria de brasileiros com dívidas.

Dessa hipótese podemos derivar algumas poucas perguntas que conduziram a nossa investigação: Qual o nível do endividamento do servidor público federal brasileiro? Quais as suas possíveis causas e consequências? Para responde-las nós estudamos a situação do servidor público federal da Fundação Universidade de Brasília (FUB) - que usaremos ao longo da dissertação com a sigla da sua universidade, UnB. É nossa percepção a representatividade dos servidores e dos professores da UnB para a realidade do endividamento do servidor público brasileiro.

A situação dos servidores da UnB é uma amostra representativa da situação dos servidores federais brasileiros. Ao analisarmos os dados disponíveis no sistema administrativo da FUB de forma a caracterizar o grau e o tipo de endividamento do servidor na Instituição, obtivemos evidências empíricas para explorarmos as possíveis causas que levam um indivíduo ao desequilíbrio financeiro pessoal e as situações em que o desequilíbrio financeiro pessoal compromete a produtividade e a qualidade de vida no trabalho. Para isso, organizamos a dissertação em três capítulos centrais, além desta Introdução e das Conclusões.

O Capítulo 1 apresenta uma revisão da literatura acadêmica sobre aquilo que podemos chamar de Economia do Endividamento. Organizados em termos de trabalhos que tratam das características da oferta e da demanda de crédito, identificamos aquilo que os estudiosos apontam como possíveis razões para o endividamento pessoal. Complementamos a revisão com considerações sobre como mudanças conjunturais da economia e da vida pessoal de

\footnotetext{
${ }^{2}$ Em síntese, a remuneração disponível é a resultante da subtração da remuneração básica (bruta) e dos descontos (consignações legais) de: PSS, IRRF, seguro de vida, plano de saúde, mensalidade de associação e outros.
} 
cidadãos e cidadãs alteram as consequências do grau de endividamento pessoal, e se a ausência da educação financeira pode ter como consequência o endividamento.

O Capítulo 2 evidencia as mudanças ocorridas na oferta e na demanda por crédito no Brasil entre o final da última década do século XX e a metade da segunda década do século XXI. Com base em dados disponíveis em fontes secundárias, caracterizamos a evolução do endividamento pessoal ao longo do período, desagregando-a por categoria profissional, servidores privados e públicos e por regiões. Nossa análise busca adiantar as possíveis causas desse crescente endividamento do brasileiro, evidenciado no capítulo anterior. Isso foi feito com base na revisão de estudos técnicos e acadêmicos disponíveis.

O Capítulo 3 dedica-se à análise da realidade do servidor público federal da UnB, seus técnicos administrativos e seus professores. Os dados da nossa pesquisa na UnB foram obtidos predominantemente dos relatórios sobre os empréstimos consignados aos servidores da Fundação Universidade de Brasília (FUB). Esses dados estão desagregados por grupos para diferentes níveis funcionais. Assim, os servidores que são docentes dividem-se por classe e os que são técnicos administrativos, por nível de escolaridade. Os servidores docentes se dividem em oito classes, de acordo com o Estatuto da $\mathrm{UnB}^{3}$. Dessas oito classes, nós analisaremos informações para cinco delas ${ }^{4}$, por limitação dos dados disponíveis. Os servidores técnico-administrativos se dividem em três níveis, de acordo com o mesmo Estatuto: fundamental, médio e superior.

A Fundação Universidade de Brasília (FUB) tem a população de 5.075 servidores, sendo 2.445 docentes e 2.630 servidores técnico-administrativos. Além das informações quantitativas, a pesquisa que fundamentou o conteúdo do Capítulo 3 foi complementada por pesquisa documental. Nessa, foram consultadas leis, estatutos que regem as IFES e relatórios de empréstimos bancários (consignados), folhas de pagamentos do Decanato de Gestão de Pessoas (DGP) da FUB, no sentido de conhecer o nível de endividamento por meio de dados demográficos da população em estudo.

A presente dissertação é encerrada com sua Conclusão, onde são apresentadas considerações a respeito do tema, de toda a pesquisa desenvolvida e de seus principais resultados.

\footnotetext{
${ }^{3} 4$ - auxiliar, 5 - assistente, 6 - adjunto, 7 - associado, 8 - titular, S - substituto, V - visitante, O - voluntário (não remunerado).

${ }^{4} 4$ - auxiliar, 5 - assistente, 6 - adjunto, 7 - associado, 8 - titular.
} 


\section{CAPÍtULO 1}

\section{ECONOMIA DO ENDIVIDAMENTO}

\subsection{Conceitos básicos de endividamento pessoal}

Toda vez que compramos algo e não pagamos naquele exato momento, estamos assumindo uma dívida. Dívida é, portanto, um compromisso - pecuniário ou patrimonial que uma pessoa - física ou jurídica - tem com outra pessoa - física ou jurídica. Tratando-se de ativos, dívida é a maneira de se usar um futuro poder de aquisição no presente antes que uma soma tenha sido ganha. Por que uma pessoa se endivida? Quais as consequências do endividamento para a pessoa endividada? Muitas pessoas altamente endividadas podem afetar o desempenho da economia local, regional ou nacional?

Muitas das respostas a essas perguntas podem ser encontradas na teoria econômica. Nós iremos destacar alguns desses conceitos aqui neste capítulo. Para que possamos evitar um tratamento superficial do assunto, iremos nos restringir ao endividamento de pessoas físicas. Ou seja, o endividamento da unidade familiar (household debt na literatura em inglês). Além disso, daremos ênfase aos conceitos que relacionam o endividamento pessoal ou familiar derivado do acesso ao crédito, uma vez que essa é a principal fonte de endividamento recente das famílias brasileiras, objeto desta pesquisa.

A última década testemunhou um interesse crescente dos economistas em relação ao endividamento da unidade familiar (BERTOLA e HOCHGUERTEL, 2005). Mesmo antes da crise econômica de 2008 - com evidentes sintomas de excesso de famílias endividadas -, economistas mostravam um óbvio interesse teórico sobre o tema, que só aumentou a partir da depressão que atingiu alguns países a partir de 2008. A disponibilidade de crédito doméstico pode proporcionar ganhos substanciais de bem-estar, pois permite possibilidades de consumo que não estariam disponíveis de outra forma naquele momento. Famílias usam crédito para financiar compras de imóvel residencial e bens de consumo duráveis. No entanto, outras formas de crédito com diferentes características também tornaram-se disponíveis para famílias usá-los para atender a necessidades específicas. Cartões de crédito e conta corrente descoberta - cheque especial - estão entre formas de crédito de (mais ou menos) fácil acesso a residências individuais.

A demanda por crédito, independentemente da forma que esse se materialize, é em última análise derivada de um determinado plano de consumo, restringindo pela renda e pelos demais gastos do demandante. Do ponto de vista do ciclo de vida do demandante, a 
equalização das utilidades marginais do consumo ao longo do tempo implica em uma demanda positiva por crédito no presente quando os ativos líquidos (acumulados por poupanças passadas) e a renda atuais estão aquém de desejos de consumo presente. A isso devemos acrescentar o caso onde o gasto e o consumo de um bem são dessincronizados no tempo, como no caso de compras de bens duráveis.

Em geral, demanda por crédito depende de características do "caminho da renda" (em particular, tempo, volatilidade e crescimento) e das atitudes dos consumidores em relação a tempo e a risco. Da mesma maneira que uma poupança pode ser gasta depois, uma dívida implica o reembolso (o pagamento) posterior de um empréstimo feito hoje. Há, portanto, interações entre preferência no tempo (time preference) e crescimento da renda e essas interações são, também, semelhantes no que diz respeito aos ativos e passivos da unidade familiar.

Padrões de empréstimos individuais dependem não só de características pessoais, mas também culturais, institucionais e do mercado de crédito. Assim várias são as razões que podem transformar um empréstimo em uma dívida. Elas podem derivar de aspectos do comportamento familiar, assim como de grande variedade de características do ambiente institucional e econômico. No Quadro 1.1 são apresentadas, com base em BCB (2013), as principais origens de dívidas pessoais. Entre elas, se destacam como as de época do ano, por impulso, crédito fácil, perda de emprego ou de parte do orçamento familiar e o pouco conhecimento financeiro. Essas podem ser denominadas as causas do endividamento pelo "lado da demanda por crédito" Há, também, causas do endividamento que têm origem do "lado da oferta de crédito". Vamos inicialmente analisar essas últimas.

\subsection{Oferta de crédito e endividamento}

O crédito é uma importante variável econômica, que promove a expansão das atividades produtivas de um país, amplia o poder de compra dos consumidores e multiplica as transações de mercado. Ainda que seja uma experiência recente no Brasil, de menos de duas décadas, o crédito para segmentos crescentes da população já transformou a economia e a vida dos brasileiros. Os ganhos socioeconômicos são evidentes e tornam o mercado consumidor brasileiro um dos mais atraentes do planeta. Com uma espetacular perspectiva de crescimento, dada a baixa relação crédito/PIB, de 46,7\%, esta é a hora do Brasil discutir o atual formato de seu sistema de crédito e os impactos sobre o endividamento do consumidor, que evolui aceleradamente (LOUREIRO, 2014). 
"A expansão do crédito à pessoa física, por significar adiantamento de gastos, vem se constituindo um dos maiores elementos do consumo. Segundo estudo do Banco Nacional de Desenvolvimento Econômico e Social (BNDES), este é o mais longo ciclo expansionista de crédito dos últimos dez anos. Apesar dos elevados juros embutidos nas prestações, a clara melhoria do cenário externo da economia brasileira, associada à manutenção da inflação em níveis reduzidos, vem permitindo a oferta com prazos dilatados, de financiamento às famílias, incorporando fatias crescentes da população ao mundo do crédito formal" (DUPAS, 2007, p. 144).

Quadro 1.1 - Origens das dívidas pessoais e familiares

\begin{tabular}{|c|c|}
\hline Origem da dívida & Descrição \\
\hline $\begin{array}{l}\text { Liberalidade na Concessão } \\
\text { de Crédito }\end{array}$ & $\begin{array}{l}\text { A oferta de crédito por instituições financeiras depende, entre diversos fatores, dos } \\
\text { cuidados que essas instituições financeiras têm na hora de conceder o crédito. Por } \\
\text { outro lado, quando garantias de pagamento dos empréstimos concedidos são } \\
\text { institucionalizadas, a tendência de um comportamento mais liberal na concessão } \\
\text { por parte dos ofertantes de crédito. }\end{array}$ \\
\hline Despesas sazonais & $\begin{array}{l}\text { São aquelas que ocorrem em determinada época do ano dificultando o orçamento } \\
\text { familiar, como pagamento de IPTU, IPVA, Imposto de Renda, material escolar, as } \\
\text { datas comemorativas como Natal, Dia das Mães, Dia das Crianças, aniversários } \\
\text { etc. Essas dívidas podem levar à necessidade de contratar uma operação de } \\
\text { crédito. }\end{array}$ \\
\hline Marketing sedutor & $\begin{array}{l}\text { São as técnicas de vendas e a tecnologia colocadas à disposição dos profissionais } \\
\text { de marketing, impulsionando as vendas bem como as compras não planejadas ou } \\
\text { realizadas por impulso, o que provoca desequilíbrios orçamentários e financeiros. }\end{array}$ \\
\hline Orçamento deficitário & $\begin{array}{l}\text { É quando a família possui um padrão de vida acima do padrão de renda. As } \\
\text { facilidades determinadas pelo crédito fácil propiciam um excesso de compras a } \\
\text { prazo que, muitas vezes, comprometem a situação financeira das famílias. }\end{array}$ \\
\hline $\begin{array}{l}\text { Redução de renda sem } \\
\text { redução de despesas }\end{array}$ & $\begin{array}{l}\text { A perda de emprego ou de parte da renda familiar sem a devida redução nas } \\
\text { despesas pode, facilmente, levar uma família ao endividamento excessivo. A } \\
\text { família deve adequar as despesas à nova realidade. }\end{array}$ \\
\hline Despesas emergenciais & $\begin{array}{l}\text { Imprevistos acontecem. Um defeito ou uma batida no veículo ou problemas de } \\
\text { saúde na família são exemplos corriqueiros. Se não houver prevenção para esses e } \\
\text { outros imprevistos a família pode cair no endividamento. }\end{array}$ \\
\hline $\begin{array}{l}\text { Separação de bens, mas } \\
\text { não dos gastos (divórcio) }\end{array}$ & $\begin{array}{l}\text { Casais se separam e dividem os bens que possuíram. Alguns gastos que eram } \\
\text { únicos ao casal, como contas de água, luz, condomínio etc., agora têm de ser } \\
\text { pagas de forma individual. Por outro lado, a receita também mudou cada um tem } \\
\text { sua renda. Obviamente, ambos têm de se ajustar a essa nova realidade financeira } \\
\text { para evitar o endividamento. }\end{array}$ \\
\hline $\begin{array}{l}\text { Pouco conhecimento } \\
\text { financeiro }\end{array}$ & $\begin{array}{l}\text { O analfabetismo financeiro é também determinante para que famílias fiquem } \\
\text { endividadas. Não conhecer o impacto que o pagamento de juros pode causar no } \\
\text { orçamento pessoal e familiar e a não leitura dos contratos firmados são situações } \\
\text { que contribuem efetivamente para o processo de endividamento. }\end{array}$ \\
\hline
\end{tabular}

O crédito pessoal é definido como uma fonte adicional de recursos obtidos de terceiros (bancos, financeiras, cooperativas de crédito e outros) que possibilita a antecipação do consumo para a aquisição de bens ou contratação de serviços. Existem várias modalidades de oferta de crédito a pessoas físicas. No Quadro 1.2 constam as principais e mais populares 
modalidades de crédito. A instituição que concede crédito recebe juros como remuneração pelo capital emprestado. Essa instituição deve (ou deveria) atentar para a capacidade de pagamento do tomador. Caso contrário corre o risco de não receber o montante emprestado de volta, com consequências para a sua própria saúde financeira.

Quadro 1.2 - Modalidade de crédito pessoa física.

\begin{tabular}{|l|l|}
\hline Modalidade de crédito & Descrição \\
\hline Cartão de crédito & $\begin{array}{l}\text { Utilizado para aquisição de bens e serviços nos estabelecimentos credenciados, } \\
\text { e a forma de pagamento pode ser à vista, a prazo ou parcelado. }\end{array}$ \\
\hline Cheque especial & Limite de crédito atrelado à conta-corrente de movimentação. \\
\hline Crédito direto ao consumidor & $\begin{array}{l}\text { Financiamento concedido para aquisição de bens e serviços, e sua maior } \\
\text { utilização é para aquisição de veículos e eletrodomésticos. }\end{array}$ \\
\hline Empréstimo em consignação & Com desconto das prestações diretamente na folha de pagamento do tomador. \\
\hline Financiamento imobiliário & $\begin{array}{l}\text { É o financiamento para compra de imóveis residenciais ou comerciais, novos } \\
\text { ou usados. É destinado a pessoas físicas e jurídicas. }\end{array}$ \\
\hline Microcrédito & Destinado à população de baixa renda e aos microempreendedores. \\
\hline Penhor & $\begin{array}{l}\text { Exclusivo da Caixa Econômica Federal tem como garantias joias em ouro, } \\
\text { prata, diamante ou outro objeto de valor. }\end{array}$ \\
\hline
\end{tabular}

Fonte: Banco Central (2013). Elaborada pelo pesquisador.

As políticas de crédito e as de risco de crédito visam a assegurar uniformidade das decisões, aperfeiçoar a administração de risco de crédito, garantir a integridade dos ativos de crédito em níveis adequados de risco e perdas e elevar os padrões de qualidade e o resultado do banco. Essas políticas são aplicadas a todos os negócios que envolvem risco de crédito, inclusive os realizados por conta e risco de terceiros, conforme regulamentações do Banco Central do Brasil (BCB). À guisa de exemplo, o processo de crédito no Banco do Brasil é constituído pelas seguintes etapas: concessão, condução, cobrança e recuperação, conforme o Quadro 1.3. 
Quadro 1.3 - Processo de crédito do Banco do Brasil.

\begin{tabular}{|c|l|}
\hline $\begin{array}{c}\text { Processo de } \\
\text { crédito }\end{array}$ & \multicolumn{1}{c|}{ Descrição } \\
\hline Concessão & $\begin{array}{l}\text { É a porta de entrada no relacionamento de crédito com o banco. Abrange a análise do } \\
\text { cliente e da operação. Na primeira, o banco utiliza métodos massificados e } \\
\text { personalizados, definindo a probabilidade de inadimplência e o limite de exposição. } \\
\text { Quanto à análise da operação, o banco busca compatibilizar a oferta de produtos de } \\
\text { créditos adequados ao perfil e à capacidade de pagamento do cliente. }\end{array}$ \\
\hline Condução & $\begin{array}{l}\text { Compreende a fase de acompanhamento da aplicação dos recursos liberados, o } \\
\text { gerenciamento das garantias, entre outras ações. O principal objetivo nesta fase é a } \\
\text { prevenção contra a inadimplência dos ativos. }\end{array}$ \\
\hline Cobrança & $\begin{array}{l}\text { Caracteriza-se pela utilização de mecanismos que asseguram o retorno dos recursos } \\
\text { emprestados, levando-se em conta algumas variáveis como o relacionamento do cliente } \\
\text { com o banco, a minimização de custos e a utilização de mecanismos autorizados de } \\
\text { cobrança e recebimento de dívidas. }\end{array}$ \\
\hline Recuperação & $\begin{array}{l}\text { Trata-se da fase em que o banco busca reduzir as perdas de crédito, minimizar os custos } \\
\text { de recuperação e aumentar a taxa de recuperação. Estão contemplados nesta etapa o } \\
\text { processo de cobrança extrajudicial, terceirização (contratação de empresas para prestar } \\
\text { serviços de cobrança e recuperação de créditos inadimplidos) e a cobrança judicial. }\end{array}$ \\
\hline Fonte: Banco do Brasil. Elaborado pelo pesquisador
\end{tabular}

O empréstimo de menor risco para quem está emprestando é o crédito consignado.

Neste, a cobrança é praticamente automática e a responsabilidade é da empresa empregadora, do sindicato ou do órgão do governo. Como o pagamento da parcela do empréstimo é garantido por desconto na folha de pagamento, há a possibilidade de empréstimo até para pessoas com o nome em registro de inadimplência no Serviço de Proteção ao Crédito (SPC) ou na Centralização de Serviços dos Bancos (Serasa) ${ }^{5}$. O crédito consignado em folha de pagamento surgiu no mercado com respaldo legal registrado na Medida Provisória n. ${ }^{\circ} 130$, de 17 de setembro de 2003, que dois meses depois se transformou na Lei n. ${ }^{\circ} 10.820$, de 17 de dezembro de 2003. Essa Lei dispõe sobre a autorização para desconto de prestações em folha de pagamento.

\begin{abstract}
Art. $1^{\circ}$. Os empregados regidos pela Consolidação das Leis do Trabalho - CLT, aprovada pelo Decreto-Lei $\mathrm{n}^{\circ}$. 5.452 , de $1^{\circ}$ de maio de 1943 , poderão autorizar de forma irrevogável e irretratável, o desconto em folha de pagamento dos valores referentes ao pagamento de empréstimos, financiamentos e operações de arrendamento mercantil concedido por instituições financeiras e sociedades de arrendamento mercantil, quando previsto nos respectivos contratos.

$\S 1^{\circ}$. O desconto mencionado neste artigo também poderá incidir sobre verbas rescisórias devidas pelo empregador, se assim previsto no respectivo contrato de empréstimo, financiamento ou arrendamento mercantil, até o limite de trinta por cento.

$\S 2^{\circ}$. O regulamento disporá sobre os limites de valor de empréstimos, de prestação consignável para fins do caput e do comprometimento das verbas rescisórias para os fins do $\S 1^{\circ}$.
\end{abstract}

\footnotetext{
${ }^{5}$ Serasa não é uma sigla. A Serasa é uma empresa privada brasileira, que faz análises e pesquisas de informações econômico-financeiros das pessoas, para apoiar decisões de crédito, como empréstimos. A Serasa foi criada pelos bancos, com o objetivo de centralizar informações, e fazer com que seus custos administrativos diminuíssem e diminuir também a margem de erros sobre as informações para emprestar crédito a pessoas. A Serasa fornece a empresa consultas sobre seus clientes, diretos e indiretos.
} 
Art. $2^{\circ}$. Para fins desta Medida Provisória, considera-se:

I - empregador, a pessoa jurídica assim definida pela legislação trabalhista;

II - empregado, aquele assim definido pela legislação trabalhista;

III - instituição consignatária, a instituição autorizada a conceder empréstimo ou financiamento ou realizar operação de arrendamento mercantil mencionada no caput do art. $1^{\mathrm{o}}$;

IV - mutuário, empregador de firma com instituição consignatária contrato de empréstimo, financiamento ou arrendamento mercantil regulado por esta Medida Provisória; e

V - verbas rescisórias, as importâncias devidas em dinheiro pelo empregador ao empregado em razão de rescisão do seu contrato de trabalho.

$\S 1^{\circ}$. Para os fins desta Medida Provisória, são consideradas consignações voluntárias as autorizadas pelo empregado.

$\S 2^{\circ}$. No momento da contratação da operação, a autorização para a efetivação dos descontos permitidos nesta Medida Provisória observará, para cada mutuário, os seguintes limites:

I - a soma dos descontos referidos no art. $1^{\circ}$ desta Medida Provisória não poderá exceder a trinta por cento da remuneração disponível, conforme definida em regulamento, e

II - o total das consignações voluntárias, incluindo as referidas no art. $1^{\circ}$, não poderá exceder a quarenta por cento da remuneração disponível, conforme definida em regulamento.

Nessa modalidade, o servidor obtém empréstimos de instituições financeiras, ou cooperativas de crédito, com as taxas de juros menores que as do mercado, não necessitando de apresentação de fiador, desde que, ao assinar o contrato, autorize expressamente o desconto em folha das parcelas relativas à amortização do empréstimo (MOREIRA, 2005, p. 191). Maia (2005, p. 1) corrobora que "o grande diferencial amplamente reconhecido, recai sobre a significativa melhora na qualidade e na liquidez da garantia oferecida, fato que acabou por provocar uma larga redução das taxas de juros incidentes em operações da espécie". A atratividade das políticas de crédito consignado viabiliza uma forte procura por esse tipo de empréstimo, porém Borrone e Sader (2008, p. 1258) pontuam que:

O problema mais comum decorrente desse tipo de empréstimo é o mau uso dos recursos, considerando-se a possibilidade de elevado endividamento pelas pessoas de baixa renda. Com o objetivo de minimizar esse problema, o Governo Federal estabeleceu como limite máximo de endividamento $30 \%$ do valor do salário, da aposentadoria ou pensão com prazos máximos para quitação de até 72 meses.

\subsection{Demanda por crédito e endividamento}

Ao utilizar o crédito, o cliente raramente verifica o seu custo relativo entre ofertantes. Comparar os preços e custos do crédito poderia ser vantajoso para o cliente. O Custo Efetivo Total (CET) é uma informação sobre quanto efetivamente custa um empréstimo ou financiamento, incluindo não somente os juros, mas também tarifas, impostos e outros encargos cobrados do cliente. A vantagem do CET é a possibilidade de comparar o que duas ou mais instituições financeiras estão oferecendo e saber qual cobra menos pelo serviço. 
Assim, dependendo dos encargos cobrados por um banco em um empréstimo, o seu CET pode acabar maior que o de outro banco, mesmo tendo uma taxa de juros menor.

Ao obter um empréstimo, o procedimento corriqueiro de simplesmente avaliar se o valor da prestação cabe no orçamento não é adequado, de uma perspectiva econômicofinanceira. É fundamental avaliar a real necessidade de crédito, comparar o CET das propostas de crédito de duas ou mais instituições financeiras e estar ciente das desvantagens e das consequências do uso de crédito. No Quadro 1.4 mostra-se que todo crédito há custo, risco e limitação.

Quadro 1.4 - Desvantagem do uso de crédito.

\begin{tabular}{|c|c|}
\hline Desvantagem & Consequência \\
\hline $\begin{array}{l}\text { Custo de antecipação do } \\
\text { consumo com o uso de crédito }\end{array}$ & $\begin{array}{l}\text { A primeira desvantagem em relação ao uso de crédito é o pagamento de } \\
\text { juros. Ao antecipar a compra de um produto ou a contratação de um serviço } \\
\text { sem a devida disponibilidade financeira, usa-se um dinheiro que não se tem, } \\
\text { portanto se paga juros por essa operação. Esse é o custo da antecipação. }\end{array}$ \\
\hline $\begin{array}{c}\text { Risco de endividamento } \\
\text { excessivo }\end{array}$ & $\begin{array}{l}\text { O uso inadequado do crédito pode comprometer a vida financeira de um } \\
\text { indivíduo, podendo ainda acarretar descontrole emocional, problemas de } \\
\text { saúde e até mesmo desestruturação familiar. }\end{array}$ \\
\hline Limite de consumo futuro & $\begin{array}{l}\text { A desvantagem de tomar crédito consiste em limitar o consumo futuro. É } \\
\text { quase automática, uma vez que o crédito tomado hoje tem de ser pago no } \\
\text { futuro. }\end{array}$ \\
\hline
\end{tabular}

A demanda por crédito pode se caracterizar por pessoas administrando mal seus recursos financeiros, sem nenhum planejamento orçamentário dos gastos pessoais, gastando mais do que ganham, não poupando e com porções crescentes da renda familiar para pagamento de dívidas. "Provavelmente existe mais de uma razão para as pessoas preferirem o fracasso ao êxito, mas a explicação fundamental é simples: para ter êxito nos negócios é necessário um interesse genuíno e sincero pela rentabilidade. E a maioria das pessoas não o tem" (SLYWOTZKY, 2002, p. 19). Cerbasi (2004) ressalta que a riqueza não depende de quanto se ganha, mas sim da forma como se gasta. A qualidade de vida está associada ao equilíbrio financeiro dos indivíduos. A liberdade de escolha para melhor administrar os próprios recursos, ou seja, satisfazer necessidades básicas com desejos de consumo e, paralelamente, formar uma poupança para suprir problemas inesperados. "Ame o que faz e o dinheiro surgirá” é o que sugere Ribeiro (1999, p. 137).

\subsection{Conjuntura econômica e endividamento}

As facilidades e as dificuldades com que se deparam os usuários do sistema creditício de um país se alteram dependendo da conjuntura econômica desse país. Segundo Almeida 
(2009), todas as crises financeiras, sem exceção, têm uma mesma causa fundamental: o excesso de liquidez, ou seja, o crescimento do numerário, como se dizia antigamente geralmente por permissividade da autoridade pública -, alimentado por ativos dos mais diversos tipos e turbinado por taxas de juros irrealistas (isto é, inferiores ao que seriam as taxas de juros "normais" de mercado).

Ainda, segundo Almeida (2009), crises financeiras são inevitáveis em economias de mercado, tendo em vista: de um lado, os interesses contraditórios entre os níveis de risco e de retorno (sempre opostos) associados às várias opções abertas à aplicação das poupanças individuais e coletivas, e de outro, os diferentes mecanismos de regulação institucionais existentes no vasto mercado de gerenciamento dessas poupanças. Credores e poupadores desejem obter, para os seus ativos, a maior taxa de juros possível, ao passo que devedores e investidores a querem no menor nível possível. O encontro dessas duas vontades deveria se realizar no mercado.

No Brasil, com a estabilidade da moeda a partir do Plano Real, o pleno emprego e a facilidade de crédito ampliaram o poder de compra dos brasileiros. A compra de bens de consumo duráveis de última geração, veículos novos e da tão sonhada casa própria se tornaram realidades na vida do cidadão brasileiro. $O$ crédito consiste em uma troca intertemporal, quando compra no presente para pagar depois, sendo a taxa de juros o meio de converter o valor da compra em prestações futuras (SOUZA, 2013, p. 13). Porém, como consequência para milhares de pessoas surgiu o endividamento.

Por um lado, a herança de antecipar consumo dos tempos dos altos índices de inflação ainda imperou no período pós-estabilidade da moeda. Por outro lado, essa cultura foi fortalecida pela democratização do crédito. Na mesma proporção em que se consegue o crédito, as pessoas se endividam cada vez mais, de forma ativa, gastando mais do que ganham, ou de forma passiva, na qual fenômenos alheios à vontade do tomador do crédito, como doença na família, levam à falta de pagamento. Surgem diversos efeitos colaterais: endividamento, inadimplência e desequilíbrio nas finanças pessoais.

O grande problema é que os bancos e as instituições financeiras cada vez mais facilitam esse crédito, oferecendo, inclusive, os créditos pré-aprovados do cartão de crédito. Toda essa facilidade em obter crédito, somada ao comportamento pouco responsável e a falta de planejamento financeiro, inevitavelmente leva às dívidas. As famílias não possuem o hábito de executar uma gestão familiar e apresentam dificuldades, como a não confrontação 
com suas rendas e desembolsos, e a ausência cultural de poupar. Como destacam Souza e Torralvo (2011), a educação financeira no Brasil não é praticada ${ }^{6}$.

As pessoas são guiadas pelo poder das imagens: o marketing agressivo força a venda dos produtos e envolve o consumidor de tal forma que fica difícil fugir do chamativo do consumo. Para as camadas sociais mais desprovidas de recursos, a situação piora quando se aceita a oferta de pagamento parcial do cartão de crédito, o que torna a dívida uma bola de neve e esse recurso financeiro o vilão do endividamento. Mas, se bem utilizado, esse dinheiro de plástico pode ser um forte aliado na tentativa de equilibrar as contas domésticas, sem deixar de satisfazer alguns bons sonhos de consumo.

O crédito, quando utilizado para o consumo, coletivamente gera um efeito positivo, pois o aumento do consumo de uma cesta de bens e serviços, suas ofertas serão aumentadas, e consequentemente, mais empregos e mais renda estarão disponíveis na economia. Porém, conforme Almeida (2012, p. 16):

Deve-se ter em mente que consumo e consumismo são entes distintos. Enquanto o consumo se revela na aquisição saudável de bens do mercado, ou seja, na aquisição do necessário para a garantia de uma existência digna, o consumismo é a compulsão por consumir. O consumismo resulta na aquisição do supérfluo, que, na verdade, é incutido na cabeça dos consumidores como necessidade (são as famosas aparentes necessidades criadas pelos fornecedores da sociedade de consumo por meio do marketing).

Em analogia com a obesidade, os endividados para pagar suas contas que se tornam resistentes e exigem doses de sacrifícios maiores, assim como os obesos para perder peso. Ganhar peso é bem mais fácil, como também é a aquisição desnecessária de bens e serviços.

Estamos amadurecendo, apesar de esse assunto ainda estar em segundo plano nos pilares de qualidade de vida, que incluem boa alimentação e cuidados com o corpo, em um futuro breve, a preocupação com o desempenho das finanças da família será tão intenso quanto é hoje a preocupação com hábitos alimentares. (CERBASI, s.d., p. digital, 2010).

O sofrimento do trabalhador em razão de atraso em suas contas a pagar já pode ser considerado um problema social. Endividamento não significa simplesmente ter prestações a pagar, e sim ter dívidas fugindo do controle orçamentário. A qualidade de vida e o equilíbrio financeiro do trabalhador, em geral, e do servidor público, em particular, refletem no aumento da produtividade e no trabalho criativo. Desse modo, endividamento individual crescente

\footnotetext{
${ }^{6}$ Sabe-se que hábitos de consumo ultrapassados são, por vezes, os causadores de dificuldades financeiras enfrentadas pelos consumidores. Endividados trabalham para quitar suas dívidas por falta de habilidades de lidar com o dinheiro, por não se preocuparem em fazer um planejamento financeiro. O que pode influenciar direta ou indiretamente a qualidade de vida. O planejamento financeiro é mais do que nunca, fundamental para uma vida equilibrada e agradável (EID JUNIOR; GARCIA, 2001).
} 
pode ter efeitos perversos sobre o desempenho de toda economia de um país, não apenas na vida dos endividados.

\subsection{Educação Financeira: sua ausência com causa do endividamento?}

É usual apontar como causa do endividamento individual o despreparo do indivíduo para a gestão de sua renda e de suas despesas. Identifica-se, assim, o indivíduo como responsável pela sua própria situação de despesas maiores que receita levando aos empréstimos e ao endividamento. Argumenta-se, ainda, que na sociedade contemporânea, globalizada e de acelerado progresso tecnológico, os indivíduos precisam cada vez mais de um amplo conjunto de informações atualizadas para o domínio de suas decisões financeiras em defesa do seu poder aquisitivo e do seu patrimônio.

Uma das formas de adquirir, pelo menos em parte, essas habilidades é por meio da educação financeira. Segundo Savoia, Saito e Santana (2007), educação financeira é um processo de transmissão de conhecimento que permite aos indivíduos desenvolverem habilidades para que possam tomar decisões fundamentais e seguras, melhorando o gerenciamento de suas finanças pessoais. Quando aprimoram tais capacidades, os indivíduos tornam-se mais integrados à sociedade e mais atuantes no âmbito financeiro, ampliando o seu bem-estar.

Para a Organização de Cooperação e Desenvolvimento Econômico - OCDE (2004), a educação financeira é importante para os consumidores por auxiliá-los a orçar e gerir sua renda além de orientá-los a poupar e investir. Já a OCDE (2005) define a educação financeira como o processo em que os indivíduos melhoram a compreensão sobre os produtos financeiros e os conceitos de riscos, de maneira que, com informação e recomendação claras, desenvolvem as habilidades e a confiança necessárias para tomarem decisões fundamentais e com segurança, melhorando o bem-estar financeiro.

Segundo Grüsner (2007), a literatura sobre finanças pessoais ainda é escassa, e muitas vezes simplista, não recebendo o devido tratamento científico e didático, visto que a educação financeira no Brasil é pouco explorada, ficando sob a responsabilidade do ambiente familiar e do interesse de cada um em adquiri-la. É evidente que o planejamento financeiro pessoal torna-se uma importante ferramenta de controle orçamentário como também é evidente que, no Brasil, não há, por parte das autoridades, a função de capacitar a população adequadamente para a tomada de decisões financeiras. De acordo com Frankenberg (1999), planejamento 
financeiro pessoal significa estabelecer e seguir uma estratégia precisa $^{7}$, deliberada e dirigida para a acumulação de bens e valores que irão formar o patrimônio de uma pessoa e de sua família, sem apontar cortes e privações como meio para o acúmulo de bens.

$\mathrm{Na}$ literatura internacional, Manson e Wilson (2000), citados por Dolvin e Templeton (2006), defendem que os programas de educação financeira estimulem o desenvolvimento de conhecimento, aptidão e habilidades, formando indivíduos críticos, informados sobre os serviços financeiros disponíveis e preparados para administrar as suas finanças de maneira eficaz. Claudino, Nunes e Silva (2009, p. 14), na análise da relação entre educação financeira e endividamento, apontam que os piores níveis de dívidas estão associados a baixo conhecimento financeiro.

De acordo com Fox, Hoffmann e Welch (2004), o Federal Reserve (Fed), o banco central norte-americano, vem atuando, de forma ativa, no levantamento de dados sobre a efetividade dos programas de educação financeira que englobam atividades direcionadas aos trabalhadores, aos estudantes e à população como um todo. Segundo Worthington (2006), o Fed criou o Jump Coalition for Personal Financial Literacy que, a cada dois anos, avalia o nível de conhecimento financeiro dos estudantes do ensino médio, colaborando para a proliferação de leis estaduais que instituem a inserção da educação financeira nas grades curriculares.

O Banco Central do Brasil - BCB possui o Programa de Educação Financeira (PEF), responsável pela orientação da sociedade a respeito de assuntos econômicos, contribuindo para um melhor entendimento dos aspectos financeiros e da responsabilidade no planejamento das finanças pessoais. Várias outras ações são desenvolvidas BCB (2006) por meio de projetos como Museu-Escola, Museu vai à Escola e Banco Central e Universidade. No entanto, Savoia, Saito e Santana (2007) perceberam que tais ações empreendidas pelo BCB não atingem, de forma ampla, o público adulto, principal usuário dos serviços financeiros. Além disso, identifica-se uma lacuna na atuação dessa Instituição evidenciada pela inexistência de uma regulamentação que exija o fomento da educação financeira por parte de bancos e de outras instituições.

Savoia, Saito e Santana (2007) concluíram, ainda, que a educação financeira no Brasil se encontra em estágio de desenvolvimento inferior à dos Estados Unidos e do Reino Unido. No primeiro, o tema é adotado obrigatoriamente na grade de ensino de alguns estados, $72 \%$

\footnotetext{
${ }^{7}$ O controle do consumo entre a receita e a despesa é fundamental para o equilíbrio financeiro. Cerbassi (2004) afirma que a riqueza não depende do que se ganha, mas sim da forma como se gasta.
} 
dos bancos promovem programas de educação financeira, além de diversas organizações engajadas nesse processo. No Reino Unido, embora seja facultativa, há um forte envolvimento dos atores do processo, inclusive com a criação de um fundo que tem o intuito de estimular a cultura de poupança. A explicação para essas diferenças pode ser históricoculturais, bem como a responsabilidade das instituições no processo de educação financeira. Pesquisas realizadas pela OCDE, em países não membros, deram origens às recomendações e aos princípios no Quadro 1.5.

\section{Quadro 1.5. Princípios e recomendações de educação financeira}

1. A educação financeira deve ser promovida de uma forma justa e sem vieses, ou seja, o desenvolvimento das competências financeiras dos indivíduos precisa ser embasado em informações e instruções apropriadas, livres de interesses particulares.

2. Os programas de educação financeira devem focar as prioridades de cada país, isto é, se adequarem à realidade nacional, podendo incluir, em seu conteúdo, aspectos básicos de um planejamento financeiro, como as decisões de poupança, de endividamento, de contratação de seguros, bem como conceitos elementares de matemática e economia. Os indivíduos que estão para se aposentar devem estar cientes da necessidade de avaliar a situação de seus planos de pensão, necessitando agir apropriadamente para defender seus interesses.

3. O processo de educação financeira deve ser considerado, pelos órgãos administrativos e legais de um país, como um instrumento para o crescimento e a estabilidade econômica, sendo necessário que se busque complementar o papel exercido pela regulamentação do sistema financeiro e pelas leis de proteção ao consumo.

4. O envolvimento das instituições financeiras no processo de educação financeira deve ser estimulado, de tal forma que a adotem como parte integrante de suas práticas de relacionamento com seus clientes, provendo informações financeiras que estimulem a compreensão de suas decisões, principalmente nos negócios de longo prazo e naqueles que comprometam expressivamente a renda atual e futura de seus consumidores.

5. A educação financeira deve ser um processo contínuo, acompanhando a evolução dos mercados e a crescente complexidade das informações que os caracterizam.

6. Por meio da mídia, devem ser veiculadas campanhas nacionais de estímulo à compreensão dos indivíduos quanto à necessidade de buscarem a capacitação financeira, bem como o conhecimento dos riscos envolvidos nas suas decisões. Além disso, precisam ser criados sites específicos, oferecendo informações gratuitas e de utilidade pública.

7. A educação financeira deve começar na escola. É recomendável que as pessoas se insiram no processo precocemente.

8. As instituições financeiras devem ser incentivadas a certificar que os clientes leiam e compreendam todas as informações disponibilizadas, especificamente, quando forem relacionadas aos negócios de longo prazo, ou aos serviços financeiros, com consequências 
relevantes.

9. Os programas de educação financeira devem focar, particularmente, aspectos importantes do planejamento financeiro pessoal, como a poupança e a aposentadoria, o endividamento e a contratação de seguros.

10. Os programas devem ser orientados para a construção da competência financeira, adequandose a grupos específicos, e elaborados da forma mais personalizada possível.

Fonte: OCDE, 2005.

Profissionais que têm uma vida financeira mais equilibrada com certeza são mais produtivos e felizes, pois sabem que têm a liberdade de ir e vir proporcionada pela segurança financeira.

"Tranquilidade econômico-financeira" é uma expressão bastante subjetiva, que
traduz o estado de satisfação de uma pessoa ao alcançar um objetivo por ela mesma
definido com o montante suficiente para manter um determinado padrão de vida.
Conceitos como riqueza, conforto, qualidade de vida, bem-estar, sucesso, renda,
fortuna etc. definem, em ultima instância, exatamente a mesma ideia.
Conscientemente, o indivíduo estabelece uma linha de conduta financeira que
gostaria de seguir e os principais objetivos que almeja alcançar na vida
(FRANHENBERG, 1999, p. 31).

Um profissional endividado fica tão preocupado em solucionar o problema e, ao mesmo tempo, ansioso pela pressão dos credores, que acaba perdendo o foco das suas atividades no dia a dia. $\mathrm{O}$ desempenho começa a ficar comprometido, e esse profissional fica desmotivado, e o gestor passa a questionar o andamento do trabalho. Com o tempo, a consequência pode ser até a perda do emprego.

O analfabetismo financeiro brasileiro foi causado por décadas de um processo inflacionário descontrolado, em que as pessoas eram impedidas de conviver com um processo de planejamento financeiro, não valia a pena guardar dinheiro, era melhor gastar logo, ou até antes do provento para não pagar juros do mês seguinte. Atualmente, mesmo com a inflação controlada, ou melhor, não descontrolada, várias pesquisas apontam que a maioria da população brasileira tem problemas financeiros como dívidas, muitas delas ocasionadas ao pouco ou nenhum conhecimento na área do endividamento financeiro.

O empréstimo a longo prazo é um dos negócios preferidos das instituições financeiras, pois por muitos anos o cidadão estará ligado a estas, pagando juros e, quem sabe, fazendo inúmeros outros negócios. (FRANKENBERG, 1999, p. 100).

No Brasil, ainda não existe de fato a prática da educação financeira. Pessoa alguma aprende como lidar com dinheiro na escola, no trabalho e muito menos em casa, onde começa todo o processo educativo. Salvo em honrosas exceções. (...) Aprender a lidar com dinheiro é uma coisa muito séria. É urgente o aprendizado, porque no Brasil já se perdeu muito tempo na ignorância (ACCIOLY, 2007). 
Por fim, segundo Claudino, Nunes, Silva (2009, p. 2), os indivíduos financeiramente educados são importantes para o desenvolvimento da economia, uma vez que estes, geralmente, formam poupança. O governo é um agente deficitário no processo da educação financeira. Os recursos poupados pelas famílias representam uma importante fonte de financiamento para os setores da economia. 


\section{CAPÍTULO 2}

\section{ENDIVIDAMENTO RECENTE DO BRASILEIRO: UMA VISÃO GERAL}

\subsection{O acesso amplo do brasileiro ao crédito}

É importante destacar que até o início do século XXI, o Brasil era um dos países onde menos se tomava dinheiro emprestado. No artigo "A importância do crédito na economia", Costa e Manolescu (2003) compararam a relação de empréstimos do País a outros países no período de 1998 à 2001. O volume de crédito no Brasil representava em média apenas $35,23 \%$ do PIB, enquanto no Reino Unido 131,28\%.

\footnotetext{
Com a ascensão de parte significativa de brasileiros na pirâmide de renda, ampliouse a fronteira de consumo. Contudo, para a maior parcela da população, apesar do avanço da renda, o acesso à aquisição, por exemplo, de um automóvel, somente é viável por meio de um financiamento. No mercado de crédito brasileiro, há o jargão que "uma prestação mensal que caiba no bolso" é o principal fator para que uma pessoa contrate um financiamento para aquisição de um bem. Assim, o tomador poderia dar menos importância à taxa de juros e ao prazo da operação, apesar de essas variáveis serem cruciais na determinação do valor da prestação mensal. Do lado das instituições financeiras (IFs) concedentes do crédito, a principal preocupação é se o financiamento será quitado. Além do risco intrínseco do tomador, as IFs tentam controlar a inadimplência considerando precipuamente a renda do tomador, ou seja, as IFs também se pautam em parte pelo critério de "caber no bolso." (TAKEDA; DAWID, 2013, p. 4).
}

Segundo Galeano e Feijó (2011, p.6), com o crescimento do crédito nos anos 2000, todos os setores de atividade aumentaram seu montante de crédito frente ao PIB. No entanto, o segmento do crédito às pessoas físicas teve um desempenho diferenciado no sentido de ter sido o que mais se expandiu. A Tabela 2.1 mostra a evolução das participações dos setores no total das operações de crédito. A participação do crédito destinado às pessoas físicas praticamente dobrou. Os setores da indústria e de habitação perderam participação no crédito, enquanto os setores rural e de comércio mantiveram suas participações. O crédito ao setor público segue uma tendência de queda: a participação caiu de 4,8\% em 2000 para 1,9\% em 2008, mas voltou a crescer em 2009 (3,2\%).

O significativo incremento do acesso ao crédito pessoal ocorrido no Brasil nas últimas duas décadas já foi brevemente destacado. Esse incremento ocorre, em um primeiro momento, após a estabilização de preços a partir de 1994. Leitão (2011, p. 433) argumenta que "ao final dos primeiros quatro anos do Plano Real, o consumo das famílias tinha crescido 50\%". O endividamento das famílias cresceu em níveis superiores ao aumento da massa salarial e do crescimento do consumo, graças à expansão do crédito. Precisamos agora enfatizar o que 
ocorreu ao longo do presente século XXI, quando os efeitos do Plano Real já não foram mais a principal causa para o aumento do acesso ao crédito. Chama a atenção do analista que na época dos dois governos de Fernando Henrique Cardoso, o endividamento das famílias brasileiras representava 6\% do PIB (Produto Interno Bruto) e no governo Lula o endividamento dos trabalhadores deu um grande salto, registrando $15 \%$ do PIB. O que aconteceu?

Tabela 2.1 - Participação em \% nos valores das operações de crédito do SFN - por setor, 2000-2009.

\begin{tabular}{lccccccc}
\hline \multicolumn{7}{c}{ Setor Público } & \multicolumn{7}{c}{ Setor Privado } \\
\hline Ano & & Indústria & Habitação & Rural & Comércio & Pessoas Físicas & Outros \\
\hline 2000 & 4,8 & 27,3 & 19,2 & 8,8 & 9,5 & 16,7 & 13,7 \\
2001 & 3,3 & 28,9 & 10,8 & 7,9 & 10,6 & 22,0 & 16,5 \\
2002 & 3,0 & 30,4 & 6,8 & 8,1 & 10,7 & 23,1 & 17,9 \\
2003 & 3,7 & 29,4 & 6,3 & 10,1 & 10,5 & 22,6 & 17,5 \\
2004 & 4,0 & 26,3 & 5,5 & 11,2 & 10,8 & 25,4 & 16,8 \\
2005 & 3,6 & 23,8 & 5,0 & 11,0 & 10,8 & 30,0 & 15,8 \\
2006 & 3,0 & 22,2 & 4,9 & 10,7 & 10,7 & 32,3 & 16,3 \\
2007 & 2,3 & 22,4 & 5,0 & 10,1 & 10,3 & 33,6 & 16,4 \\
2008 & 1,9 & 23,3 & 5,0 & 9,1 & 10,3 & 33,2 & 17,2 \\
2009 & 3,2 & 22,9 & 5,9 & 8,3 & 9,6 & 32,9 & 17,2 \\
\hline
\end{tabular}

Fonte: BCB, 2010.

\subsection{Comportamento do endividamento pessoal entre 2000 e 2014}

O Banco Central do Brasil (BCB) confirma o quê para muitos é só um mito: sem perceber, o consumidor está carregando cada vez mais dinheiro no bolso. Em um ano, o volume de papel-moeda em circulação no País ampliou-se em quase $\mathrm{R} \$ 20$ bilhões. Ao todo, a quantidade de cédulas e moedas que correm de mão em mão subiu de $\mathrm{R} \$ 166$ bilhões (março/2013) para R \$ 185,2 bilhões (fevereiro/2014). A tabela 2.2 mostra a quantidade de papel-moeda em circulação no período de dezembro de 2012 a fevereiro de 2014.

Esses recursos, no entanto, cobriram a demanda da sociedade por dinheiro, sem necessariamente representar ganho real para qualquer cidadão, como explica José Luis Oreiro, do Instituto de Economia da Universidade Federal do Rio de Janeiro (UFRJ) ${ }^{8}$. "Quando a inflação acelera as pessoas necessitam de mais moeda", resume. Ainda, segundo José Luis

\footnotetext{
8 Artigo postado em 27/04/2014 06h00min / atualizado em 27/04/2014 07h22min / "Brasileiros usam mais papel-moeda para suprir necessidades" / Correio Brasiliense.
} 
Oreiro, a escalada da inflação turbinou o volume de dinheiro em circulação, mas não explica sozinho o fenômeno. Em 2013, o Índice de Preços ao Consumidor Amplo (IPCA) subiu $5,91 \%$. No mesmo ano, o governo ampliou em $10 \%$ a quantidade de recursos que corriam de mão em mão, ocorrendo assim uma "monetização" da economia. "Para fugir das taxas do cartão de crédito, muitos lojistas oferecem descontos a quem paga com dinheiro", exemplifica.

Tabela 2.2 - Papel-moeda em circulação do público - Dez 2012 / Fev 2014.

\begin{tabular}{lcc}
\hline \multicolumn{1}{c}{ Período } & $\mathrm{R} \$$ em bilhões & Em 12 meses, em \% \\
\hline dezembro / 2012 & 180,0 & 12,6 \\
janeiro / 2013 & 172,6 & 12,1 \\
fevereiro / 2013 & 169,0 & 11,5 \\
março / 2013 & 166,0 & 12,3 \\
abril / 2013 & 164,4 & 11,5 \\
maio / 2013 & 165,3 & 11,7 \\
junho / 2013 & 166,8 & 11,2 \\
julho / 2013 & 169,2 & 10,3 \\
agosto / 2013 & 170,5 & 10,6 \\
setembro / 2013 & 176,1 & 9,5 \\
outubro / 2013 & 176,6 & 9,1 \\
novembro / 2013 & 179,5 & 11,0 \\
dezembro / 2013 & 198,4 & 10,0 \\
janeiro / 2014 & 189,9 & 10,0 \\
fevereiro / 2014 & 185,2 & 9,6 \\
\hline
\end{tabular}

Fonte: Banco Central.

Um fator que isoladamente contribuiu para o crescimento do crédito nos últimos anos foi a queda da taxa de juros. Até o fim de 2007, as taxas de juros anuais cobradas apresentaram forte tendência de queda, passando de 45\% ao ano, entre 2004 e 2006, para menos de $35 \%$ no final de 2007. No entanto, essa tendência foi revertida ao longo de 2008 quando as taxas voltaram a subir, encerrando o ano acima de $40 \%$, voltando a cair depois da crise financeira internacional (BCB, 2010).

A Pesquisa Nacional de Endividamento e Inadimplência do Consumidor (PEIC) realizada em janeiro de 2012 mostrou que 58\% das famílias brasileiras estavam endividadas. Dessas, 6,9\% admitiam que não teriam condições de quitar suas dívidas. $\mathrm{Na}$ verdade, evidências desse endividamento já haviam sido apresentadas por outras instituições. Segundo dados divulgados no portal eletrônico do Superior Tribunal de Justiça (STJ) em sua edição de 
13 de dezembro de 2011, o superendividamento era uma realidade para mais de $9 \%$ das famílias brasileiras. Destacava a mesma fonte que desde a crise internacional de 2008, quando o Governo Federal decidiu aumentar a oferta de crédito para manter a economia aquecida, os brasileiros nunca deveram tanto e nunca comprometeram parcela tão grande do salário para pagar dívidas.

Pesquisa recentemente divulgada pelo BCB (2011) revelou que cada brasileiro devia cerca de $42 \%$ da soma dos salários do ano de 2011 inteiro, o que representava um recorde. As pessoas físicas deviam quase $\mathrm{R} \$ 716$ bilhões aos bancos em operações simples, como o microcrédito e o cheque especial, até financiamentos longos, como o imobiliário e de veículos, passando pelo cartão de crédito.

Segundo a Pesquisa de Orçamentos Familiares (POF) 2008-2009, 40 milhões de famílias brasileiras, $68,4 \%$ do total, chegam ao fim do mês sem fechar suas contas. Suas despesas mensais superam seus rendimentos. Essa realidade estava presente em um universo ainda maior de famílias em 2002-2003, 85,3\% do total. Quando perguntadas sobre sua percepção com relação ao orçamento familiar, 75,2\% das pessoas relatam ter dificuldade para chegar ao fim do mês com o seu orçamento. O déficit na conta bancária, segundo o Instituto Brasileiro de Geografia e Estatística (IBGE), ocorre nas famílias com rendimento de até R\$ 2.490,00. "Essas pessoas certamente têm que recorrer ao endividamento para consumir e fazer frente a outras despesas", diz Sônia Rocha, economista do Instituto de Estudos do Trabalho e Sociedade (IETS). (ROCHA, 2010).

O Instituto de Pesquisa Econômica Aplicada (IPEA) publicou, em 31 de agosto de 2010, a primeira medição do Índice de Expectativa das Famílias (IEF), indicador mensal apurado com base em pesquisa domiciliar realizada em todas as unidades da Federação. O principal objetivo do IEF é medir a percepção das famílias sobre sua condição financeira em comparação à de um passado recente e as expectativas para um futuro de curto a médio prazo. Assim, o IEF é um índice que resume a percepção das famílias brasileiras em relação a um conjunto de questões como (i) a situação econômica nacional; (ii) a condição financeira passada e a expectativa futura; (iii) decisões de consumo; (iv) endividamento e as condições de quitação de dívidas e contas atrasadas; e (v) o mercado de trabalho, especialmente nos quesitos segurança na ocupação e sentimento futuro de melhora profissional.

Considerando esse conjunto de variáveis, o Índice de Expectativas das Famílias brasileiras em agosto de 2010 atingiu 62,75 pontos, um índice considerado como revelador de otimismo em relação à situação sócio econômica do país. Apesar desse otimismo (ou por causa dele), o endividamento do trabalhador brasileiro continuou tomando conta do País, e é 
difícil alguém não conhecer uma pessoa que não esteja endividada. Um estudo intitulado "Radiografia do Endividamento das Famílias nas Capitais Brasileiras", realizado em julho de 2011, pela Federação do Comércio do Estado de São Paulo (FECOMÉRCIO-SP), aponta que 64\%, em média, das famílias que vivem nas 27 capitais do País tinham dívidas entre janeiro e maio daquele ano. No mesmo período, em 2010, o endividamento era de 61\%. Havia capitais nas quais o endividamento era quase absoluto. Curitiba (PR), por exemplo, tinha $88 \%$ das famílias endividadas; seguida por Florianópolis (SC), cujo índice era de 86\%, ou seja, quase nove entre 10 famílias estão endividadas nessas capitais.

O crédito, como relevante instrumento de fomento econômico, assumiu um caráter
de grande importância na sociedade capitalista. Pois, devido ao abandono de seu
antigo estigma (sinônimo de pobreza), ele passou a permitir a uma parcela
considerável da população acesso a produtos e serviços até então inatingíveis,
considerando o poder aquisitivo deste segmento social. E é este mesmo crédito,
então, que antes consistia num mero recurso de acesso a bens de consumo
indispensáveis. Era buscado por aquele empregado que não conseguia terminar o
mês com seu salário e tinha, geralmente, um fim de alavancar a demanda doméstica.
Era relegado àqueles que não dispunham de outro meio para a manutenção própria e
familiar (ALMEIDA, 2012 p. 15).

Segundo um estudo da LCA Consultores, divulgado pelo jornal "O Estado de São Paulo", em abril de 2011, o total da dívida das pessoas físicas chegou a R\$ 653 bilhões e, em dezembro de 2009, a dívida das famílias estava em $\mathrm{R} \$ 485$ bilhões. O crescimento econômico foi o pano de fundo do endividamento dos trabalhadores. $\mathrm{O}$ crescimento fez com que bancos e financeiras abrissem as torneiras do crédito, com prazos a perder de vista. Assim, muitos trabalhadores acabaram contraindo dívidas no cartão de crédito, cheque especial, financiamento bancário, crédito consignado, para compra de veículos e imóveis. O endividamento dos trabalhadores tornou-se uma estratégia das empresas para expansão dos seus rendimentos. As práticas como créditos longos, facilidades na aquisição de cartão de crédito, cheque especial, e muitas outras, permitem que os capitalistas lucrem mais nos financiamentos dos produtos que vendem do que com a venda em si do produto.

A Tabela 2.3 mostra a evolução do crédito para as pessoas jurídicas e físicas nos anos de 2010, 2011 e 2012 e a porcentagem do PIB no Brasil. O saldo total das operações de crédito do sistema financeiro, computados os recursos livres e direcionados, alcançou $\mathrm{R} \$$ 2.368,4 trilhões em dezembro de 2012, com expansão anual de 16,4\%, ante 18,8\% em 2011 e 20,6\% em 2010, passando a representar, relativamente ao Produto Interno Bruto (PIB), $53,8 \%$, ante 49,1\% em 2011 e 45,4\% em 2010. Por segmento, as carteiras de crédito referentes a pessoas jurídicas e a pessoas físicas totalizaram $\mathrm{R} \$ 1.292,5$ trilhão e $\mathrm{R} \$ 1.075,9$ trilhão, após elevações anuais de 16,1\% e 16,8\% em 2012, respectivamente. 
Tabela 2.3 - Evolução geral do crédito - 2010 a 2012 .

$\mathrm{R} \$$ bilhões

\begin{tabular}{|c|c|c|c|c|c|}
\hline \multirow[t]{2}{*}{ Discriminação } & \multirow[t]{2}{*}{2010} & \multirow[t]{2}{*}{2011} & \multirow[t]{2}{*}{2012} & \multicolumn{2}{|c|}{ Variação \% } \\
\hline & & & & 2011 & 2012 \\
\hline Pessoas Jurídicas & 936,3 & $1.112,9$ & $1.292,5$ & 18,9 & 16,1 \\
\hline Recursos livres & 502.6 & 603,8 & 706,1 & 20,1 & 17,0 \\
\hline Direcionados & 433,7 & 509,1 & 586,0 & 17,4 & 15,1 \\
\hline Pessoas físicas & 776,4 & 921,1 & $1.075,09$ & 18,6 & 16,8 \\
\hline Recursos livres & 555,2 & 628,4 & 692,7 & 13,2 & 10,2 \\
\hline Direcionados & 221,2 & 292,7 & 383,2 & 32,3 & 30,9 \\
\hline Total PJ+PF & $1.712,7$ & $2.038,0$ & $2.368,4$ & 18,8 & 16,4 \\
\hline \multicolumn{6}{|l|}{$\overline{\text { Participação (\%) }}$} \\
\hline \multicolumn{6}{|l|}{ Total / PIB } \\
\hline Pessoas jurídicas / PIB & 24,8 & 26,9 & 29,4 & & \\
\hline Pessoas físicas / PIB & 20,6 & 22,2 & 24,4 & & \\
\hline Recursos livres / PIB & 28,1 & 29,2 & 31,8 & & \\
\hline Recursos direcionados / PIB & 17,4 & 19,4 & 22,0 & & \\
\hline Total PJ/PIB+PF/PIB & 45,4 & 49,1 & 53,8 & & \\
\hline
\end{tabular}

Fonte: Banco Central (2012).

Já a Tabela 2.4 mostra a evolução do crédito a pessoas físicas nos anos de 2010, 2011 e 2012 discriminando os recursos livres e direcionados. Os empréstimos a pessoas físicas cresceram 10,2\%, ao atingir saldo de R $\$ 629,7$ bilhões em 2012, sobressaindo-se as expansões do crédito consignado, cartão de crédito e aquisição de veículos, bem como recuo das operações de arrendamento mercantil. No que se refere ao crédito com recursos direcionados que foi concedido a pessoas físicas, em 2012 a expansão alcançou 30,9\% (e o estoque, R \$ 383,2 bilhões), com destaque para os financiamentos imobiliário e rural. 
Tabela 2.4 - Evolução do Crédito a pessoas físicas - Saldos - 2010 a 2012.

R\$ bilhões

\begin{tabular}{|c|c|c|c|c|c|}
\hline \multirow[t]{3}{*}{ Discriminação } & 2010 & 2011 & 2012 & \multirow{2}{*}{\multicolumn{2}{|c|}{ Variação \% }} \\
\hline & & & & & \\
\hline & & & & 2011 & 2012 \\
\hline Recursos livres & 555,2 & 628,4 & 692,7 & 13,2 & 10,2 \\
\hline Crédito pessoal & 201,6 & 238,9 & 279,1 & 18,5 & 16,9 \\
\hline Consignado & 136,3 & 159,3 & 188,9 & 16,9 & 18,5 \\
\hline Aquisição de veículos & 140,3 & 177,7 & 193,2 & 26,6 & 8,8 \\
\hline Cartão de crédito & 100,1 & 114,0 & 126,5 & 13,9 & 11,0 \\
\hline Cheque especial & 16,3 & 17,6 & 18,3 & 8,2 & 4,0 \\
\hline Demais & 96,9 & 80,2 & 75,6 & $-17,2$ & $-5,8$ \\
\hline Recursos direcionados & 221,2 & 292,7 & 383,2 & 32,3 & 30,9 \\
\hline BNDES & 22,3 & 24,8 & 29,2 & 11,1 & 17,8 \\
\hline Imobiliário & 131,3 & 189,4 & 255,4 & 44,2 & 34,8 \\
\hline Rural & 61,4 & 72,6 & 90,7 & 18,3 & 24,8 \\
\hline Demais & 6,2 & 5,9 & 8,0 & $-4,6$ & 36,1 \\
\hline
\end{tabular}

Os dados da Pesquisa de Endividamento e Inadimplência do Consumidor (PEIC), divulgados mensalmente pela Confederação Nacional do Comércio de Bens, Serviços e Turismo (CNC), mostram que em 2013, em média, 62,5\% das famílias brasileiras declararam ter dívidas entre cheque pré-datado, cartão de crédito, carnê de loja, empréstimo pessoal, prestação de carro e seguro. O percentual de famílias brasileiras que declararam ter dívidas ou contas em atraso foi, em média, 21,2\%. As famílias que disseram não ter condições de pagar suas dívidas e contas em atraso e que, portanto, continuariam inadimplentes representaram 6,9\% do total na média de 2013.

Na comparação entre os anos de 2012 e 2013, observou-se aumento do percentual de famílias endividadas, que passou de uma média anual de 58,3\% do total de 2012 para 62,55\% de 2013. Em 2014, a PEIC registrou e a CNC divulgou que o percentual de famílias endividadas caiu e a proporção das inadimplentes manteve-se estável na passagem de agosto para setembro, variando de $63,6 \%$ para $63,1 \%$. A PEIC mostra que o percentual de pessoas endividadas caiu de $12,4 \%$ em agosto para $11,5 \%$ em setembro.

A pesquisa da CNC, (2014) também mostrou que as principais dívidas das famílias são com cartões de crédito, carnês, financiamento de carro, crédito pessoal, financiamento de 
casa e cheque especial. O tempo médio do atraso do pagamento das dívidas é 58,4 dias. Em média, as famílias comprometem $30 \%$ de suas rendas com isso. O percentual de famílias que não terão condições de pagar suas dívidas caiu de 6,5\% em agosto para 5,9\% em setembro. Essas informações sobre as principais dívidas das famílias em 2014 estão na tabela 2.5.

Tabela 2.5 - Percentual das principais dívidas das famílias - 2014.

\begin{tabular}{lr}
\hline Cartões de crédito & $75,1 \%$ \\
Carnês & $17,3 \%$ \\
Financiamento de carro & $14,1 \%$ \\
Crédito pessoal & $9,6 \%$ \\
Financiamento de casa & $8,2 \%$ \\
Cheque especial & $5,8 \%$ \\
\hline
\end{tabular}

Fonte: $\mathrm{CNC}-2014$

Em comparação a setembro de 2013, a pesquisa mostra que houve aumento do endividamento e quedas na inadimplência e no percentual de famílias sem condições de pagar as dívidas, já que naquela ocasião, os percentuais eram respectivamente $61,4 \%, 20,6 \%$ e $7 \%$. A economista da CNC Marianne Hanson pontua:

As famílias continuaram se endividando neste ano, mas o perfil de endividamento
está melhorando. A gente pode ver isso através da PEIC, que mostra dados mais
favoráveis de inadimplência [em relação a 2013] e na percepção das famílias sobre
suas dívidas, já que uma proporção menor disse estar muito endividada. E também
através dos dados de crédito, que tem crescido de forma mais moderada. (HANSON,
2014).

De acordo com o relatório de operações de crédito divulgado dia 30 de outubro de 2014 pelo Banco Central do Brasil (BCB), em setembro, a média diária de concessão de recursos destinados às pessoas físicas teve alta de 7,6\% ante ao mesmo mês de 2013. Esse procedimento foi devido, principalmente, ao avanço de $11 \%$ nas operações de cartão de crédito. A taxa média de juros ao consumidor (42,8\% ao ano) variou 5,5 pontos percentuais em relação àquela observada em setembro de 2013, com avanço mais significativo no custo do cheque especial ( +40 pontos percentuais para $183,3 \%$ ao ano).

Concretizando as atuais previsões para a evolução do PIB em $2014(+0,3 \%)$ e para a taxa básica de juros ao final do ano (11\% ao ano), a relação crédito PIB deverá ser 58,4\% em dezembro de 2015, 4,5 pontos percentuais acima do nível observado em dezembro de 2013. Já o crédito ao consumidor registrou, ao término de 2014 , um crescimento real de $4,7 \%$ em relação ao ano anterior (contra $+4,8 \%$ na previsão anterior) com taxas de juros ao tomador atingindo $42,6 \%$ ao ano. 
Fica evidente, então, que há um crescimento do endividamento do brasileiro ao longo dos quatorze primeiros anos do século XXI. É nosso entendimento que esse endividamento apresenta características específicas para diferentes categorias profissionais de trabalho, assim como especificidades regionais. As duas próximas seções desta dissertação tratam de analisar as evidências empíricas disponíveis sobre essas duas desagregações.

\subsection{Endividamento por categoria profissional}

\subsection{1 - Servidores Privados e em Geral}

Há por parte do Sistema Financeiro (Bancos e Cooperativas) certa resistência na concessão de empréstimos consignados, aqueles com desconto em folha de pagamento, para os trabalhadores da iniciativa privada. O problema é que esta categoria, por não ter estabilidade no emprego, a mudança é constante, bem como, a folha de pagamento.

O Governo Federal, por meio do Ministério da Fazenda anunciou em 2014 medidas para facilitar o sistema de cobrança dos empréstimos consignado ao setor privado. A mudança anunciada pelo governo vai equiparar o sistema de cobrança do consignado privado ao sistema adotado para o consignado do INSS e os trabalhadores do setor público. A medida visa aprimorar a segurança jurídica do crédito consignado privado, reduzindo o risco de inadimplência, facilitando assim o acesso desses trabalhadores a crédito mais barato.

Segundo o Banco Central do Brasil, em julho de 2014 o saldo do crédito consignado ao setor público acumulava $\mathrm{R} \$ 148,8$ bilhões, a do INSS, R \$73,1 bilhões enquanto ao do setor privado, apenas $\mathrm{R} \$ 18,9$ bilhões. Com o estímulo à oferta do empréstimo consignado para trabalhadores da iniciativa privada, o governo federal pretende levar a esse grupo os juros menores cobrados por esta modalidade, na comparação com o crédito pessoal, por exemplo. Mesmo assim, as taxas cobradas no consignado para trabalhadores do setor privado ainda são um pouco maiores do que as praticadas para servidores públicos e aposentados e pensionistas da Previdência Social. A média dos juros do crédito pessoal é de 100,3\% ao ano. As taxas médias do consignado são de 23,6\% ao ano para os servidores público, 27,9\% ao ano para os segurados do INSS e de 32,4\% ao ano para os funcionários do setor privado.

O setor privado que buscar o crédito consignado poderá autorizar a instituição financeira a debitar o valor da prestação simultaneamente ao crédito do salário em conta corrente. Atualmente, o desconto é feito de duas formas: a empresa pagadora retém e depois repassa para a instituição financeira ou o valor da prestação é debitado pela instituição financeira ao final do dia. Após a Medida Provisória, as instituições financeiras terão mais segurança para oferecer a linha de crédito, hoje uma das mais baratas do mercado. Estes 
trabalhadores poderão melhorar o perfil de sua dívida, principalmente as mais caras, como cartão de crédito e cheque especial.

\subsection{2 - Servidores Públicos}

Os servidores públicos devem $\mathrm{R} \$ 135,2$ bilhões aos bancos por meio de empréstimos consignados, volume 7,5 vezes maior que os débitos de trabalhadores da iniciativa privada, segundo o Banco Central (2013). O montante é duas vezes superior aos R\$ 65,7 bilhões de outra categoria profissional, os beneficiários da Previdência que devem às instituições financeiras, na mesma modalidade de crédito. Em setembro de 2013, a renda média dos servidores foi de $\mathrm{R} \$ 3,2$ mil, 84,5\% acima da registrada entre os profissionais do setor privado com carteira assinada, de $\mathrm{R} \$ 1,7$ mil. No acumulado do ano, os recursos a serem descontados na folha de pagamento do setor público cresceram $16,5 \%$ acima dos $12 \%$ do total geral das operações.

Os dados surpreendem, uma vez que a soma de servidores estatutários e militares no País, conforme pesquisa do IBGE, chega a 6,9 milhões de pessoas ante 46,6 milhões de trabalhadores do setor privado e 27,7 milhões de segurados da Previdência. Dois fatores ajudam a explicar o forte endividamento do funcionalismo público: a estabilidade no emprego e o salário maior. Supervisionados pelo Ministério do Planejamento, os empréstimos consignados do funcionalismo Federal têm limite legal de comprometimento da renda de no máximo $30 \% \%^{9}$. As dívidas podem ser pagas em até 60 parcelas. O problema, ressaltaram técnicos do Banco Central, é que boa parte dos servidores, além do consignado, acumula débitos pesados no cartão de crédito e está atolada no cheque especial, o qual tem as maiores taxas de juros do mercado, de $10 \%$ ao mês, em média. Também há muitos pagando prestações de carros e da casa própria.

Segundo o chefe do Departamento Econômico do Banco Central, Tulio Maciel, com as características diferenciadas do funcionalismo, que reduzem os riscos de calotes, os bancos se sentem mais confortáveis em emprestar para esse público. Soma-se a isso o fato de os brasileiros estarem cada vez mais informados sobre o custo do crédito, o que os leva a buscar linhas de financiamento com taxas mais baixas. Na média, os juros dos empréstimos com desconto em folha para o funcionalismo estão $22,4 \%$ ao ano, contra $88,1 \%$ anuais do crédito

\footnotetext{
${ }^{9}$ A Medida Provisória 661/14 foi alterada para ampliar o teto do endividamento de trabalhadores, aposentados e pensionistas no crédito consignado. Hoje além dos $30 \%$ os trabalhadores da ativa podem autorizar mais $10 \%$ para pagamento de convênios com farmácias, supermercados, plano de saúde, previdência privada e seguros. Para eles passa de $40 \%$ para 50\%. Para aposentados e pensionistas o limite sobe de $30 \%$ par $40 \%$. Em 07/04/2015 Notícias da Câmara.
} 
pessoal normal e $144,5 \%$ do cheque especial. "Percebemos que o crédito com menor custo ganha mais espaço em detrimento do mais caro". (MACIEL, 2014).

A despeito dos juros menores, o endividamento crescente dos servidores públicos merece atenção, afirma o educador financeiro Mauro Calil. Para ele, é preciso muita cautela na hora de se tomar qualquer empréstimo ou financiamento, de forma a se evitar desequilíbrios desnecessários no orçamento doméstico. O ideal, destacou, é que as pessoas, e isso vale para todos os consumidores, façam uma poupança para comprar à vista em vez de recorrerem a empréstimos para consumir. Calil destaca ainda que o endividamento, mesmo que justificável, não deve ser exagerado, pois o pagamento de prestações compromete a margem de flexibilidade da renda familiar quando surgir uma eventualidade, como uma doença.

Calil assinala que, nos casos em que os consumidores estiverem com a "corda no pescoço", o ideal é verificar o saldo da dívida, qual a instituição credora, as taxas de juros que estão sendo pagas e o prazo da dívida. "Depois disso, negociem condições melhores e, se for necessário, vendam um bem, como um carro, para diminuir a dívida ou quitar o total dos débitos. As pessoas precisam seguir esse planejamento à risca, porque qualquer deslize pode comprometer a renda de toda a família". (CALIL, 2014).

Como já foi dito, a categoria de servidores públicos é a que mais se endividou. No Brasil essa categoria é dividida de acordo com os três Poderes: Executivo, Legislativo e Judiciário. Entre esses Poderes, apesar de ser uma garantia constitucional, não existe isonomia salarial. Assim, os maiores salários são os dos Poderes Legislativo e Judiciário. Uma pesquisa realizada pelo site do Sindicato dos Servidores do Poder Legislativo e do TCU (Sindilegis) veio comprovar o ditado: "quem mais ganha, mais gasta". A pesquisa comprova o alto grau de endividamento dos servidores, principalmente por conta dos descontos consignados. Ao serem questionados sobre como está a sua situação financeira, $87 \%$ deles informaram estar endividados, e, desse percentual, apenas $28 \%$ afirmaram estar com as dívidas sob controle.

Os números são alarmantes e confirmam o alto grau de comprometimento da renda desses servidores. $\mathrm{O}$ sindicato informa ainda que diversos fatores levam uma pessoa a se endividar, algumas situações atípicas contribuíram para levar o servidor a essa situação. No Senado, muitos servidores foram prejudicados pela prática abusiva de algumas instituições financeiras e se encontram com quase toda sua renda mensal comprometida após negociações que ferem normas preceituadas pela legislação que rege os empréstimos consignados, sem qualquer tipo de fiscalização pela direção da Casa. Na Câmara, a inclusão dos valores correspondentes a adicionais de função comissionada no cômputo da margem consignável 
prejudicou os servidores que as perderam depois de contraído empréstimo. Outro fator foi a retirada da mensalidade do plano de saúde para efeito de margem consignável. Por conta dos empréstimos, muitos servidores abriram mão de ter o benefício da assistência médica.

No artigo "Endividamento e seus reflexos em profissionais do Direito", Vladimir Passos de Freitas (2012), aponta que a facilidade na obtenção de créditos, o poder de convencimento de propagandas feitas com competência, a vontade de distinguir-se pela aparência, de exibir sucesso, e até mesmo por solidão (o vendedor passa a ser alguém com quem conversar por algum tempo) são, entre outros, motivos que desequilibram as finanças e muitos começam a viver maus momentos, passando pelas mãos de credores nem sempre bem intencionados, comprometendo a vida profissional e, por vezes, da família.

Esse é um fenômeno que atinge todas as categorias profissionais. No mundo empresarial, o problema sucede com tanta frequência, que a Revista Você S.A. dedica, em todos os seus números, estudos e entrevistas orientando seus leitores a aplicar bem o dinheiro. Na edição do mês de julho de 2012, a reportagem "Dinheiro", de Roseli Loturco, mostra que evitar um jantar de R \$ 100 por semana poderá resultar, bem aplicados, em R \$29.792,56 ao fim de 5 anos (p. 79). Por tudo isso, alguns, mesmo recebendo $\mathrm{R} \$ 30$ mil por mês, sempre têm dívidas. Se receberem $\mathrm{R} \$ 40$ mil, será a mesma coisa. E, obviamente, não se preocupam em destinar R\$ 100 a um plano de previdência privada, que lhes daria conforto na velhice.

Observa-se como a má administração das finanças ocorre no universo jurídico e as consequências que isso resultam. Advogados têm vida muito diferente dos servidores públicos. A começar pelo fato de que podem ir aos extremos, desde sobreviver com $\mathrm{R} \$ 1,2$ mensais pagos por um escritório pequeno até tornarem-se extremamente ricos em casos de muito sucesso. Mas, tomando por base um profissional mediano, o problema surge quando ele se excede, por qualquer motivo, nas despesas, valendo-se do dinheiro depositado a favor de algum cliente, ainda que com a intenção de pagar-lhe depois. Os Tribunais de Ética da OAB veem-se, não raramente, às voltas com tal tipo de problema e muitas carreiras promissoras se acabam.

No serviço público, a situação é um pouco diferente. Mesmo as profissões bem remuneradas (carreiras de estado) têm grande quantidade de profissionais endividados. É que a ambição não se satisfaz com R $\$ 25$ mil (brutos, é verdade) mensais. Outros, impressionados com as roupas de marca do vizinho industrial, com o veículo do amigo de infância bem sucedido, que mal entra na garagem, ou com a lancha do advogado tributarista que foi seu colega de faculdade, desdobra-se em exibições de poderio econômico, que resultam em frequentes visitas ao gerente do banco, para renovar empréstimos. Esse problema vem 
assumindo proporções tão graves que há tribunais limitando os descontos em folha de pagamento. O percentual é de 30\%, mas com acréscimos de financiamento de imóvel e pensão alimentícia, por vezes, chega a $70 \%$.

O servidor, em sentido amplo, perde a própria autonomia de vontade. E o devedor poderá ser uma vítima do credor. Como reagirá um promotor de Justiça ao acusar alguém defendido por um advogado que é seu credor? Que independência terá um desembargador para julgar um recurso de grande repercussão econômica para um banco do qual é antigo devedor? O servidor de um cartório dará preferência aos processos de um advogado a quem deve certa quantia?

Os órgãos públicos não devem ignorar o problema. Deve-se contatar consultores financeiros para que orientem, (inclusive magistrados e agentes do MP) nos cursos que se realizam após a posse, que vencimentos passam por ciclos e que é preciso se preparar e adaptar-se às épocas de má remuneração bem como a utilização adequada dos rendimentos, como registrando todos os gastos do mês, para saber onde cortar, permitindo maior proveito desses rendimentos. Em casos extremos, auxílio psicológico não deve ser descartado. Em suma, sem precisar ir ao ponto de pertencer a grupos de "Devedores Anônimos" (em São Paulo já existem três), é necessário reconhecer e enfrentar o problema. Antes que se chegue a situações extremas como a do distribuidor judicial registrar execução contra alguém do andar de cima e a do oficial de Justiça sentir-se constrangido em ter que citar a própria chefia.

\subsection{Endividamento por região}

Os dados da PEIC, divulgados mensalmente pela CNC, mostram o perfil regional de endividamento e inadimplência das famílias brasileira. Em 2013, 62,5\% das famílias brasileiras declararam ter dívidas entre cheque pré-datado, cartão de crédito, carnê de loja, empréstimo pessoal, prestação de carro e seguro. No corte regional da pesquisa, que é feita em todas capitais do País, a região Sul apresentou maior proporção de endividados em relação ao total de famílias, com $76 \%$, enquanto a região Sudeste apresentou apenas 56,3\%, o menor nível na comparação regional.

A Tabela 2.6. mostra a síntese dos resultados das médias regionais de endividamento e inadimplência das famílias brasileiras em 2013. 
Tabela 2.6. - Síntese dos resultados - médias por região em 2013.

\begin{tabular}{lcccccc}
\hline Taxa & Brasil & Norte & Nordeste & Sudeste & Centro Oeste & Sul \\
\hline Total de endividados & $62,52 \%$ & $68,2 \%$ & $65,8 \%$ & $56,3 \%$ & $67,8 \%$ & $76 \%$ \\
\hline Dividas ou contas em atraso & $21,2 \%$ & $25 \%$ & $23,4 \%$ & $18,8 \%$ & $18,9 \%$ & $21,9 \%$ \\
\hline Não terão condições de pagar & $6,9 \%$ & $3,4 \%$ & $7,4 \%$ & $7,2 \%$ & $5,5 \%$ & $8,8 \%$ \\
\hline Fonte: PEIC/CNC -2013.
\end{tabular}

O percentual de famílias brasileiras que declararam ter dívidas ou contas em atraso foi, em média, 21,2\% do total de famílias nesse mesmo período. A região Norte apresentou o maior percentual de famílias inadimplentes, com 25,9\% do total. Com 18,8\% do total de famílias, o Sudeste foi a região que apresentou menor proporção de famílias com contas ou dívidas em atraso. As famílias que disseram não ter condições de pagar suas dívidas e contas em atraso representaram 6,9\% do total da média em 2013. A região Sul foi a que apresentou a pior percepção dos inadimplentes em relação à sua capacidade de pagamento, 8,8\% do total de famílias relatando que não teriam condições de pagar. Na região Norte, apesar de contar com a maior proporção de inadimplentes, observou-se o menor percentual de famílias que declararam não ter condições de pagar, com 3,4\% do total.

Outros dados da PEIC, divulgados pela CNC em dezembro de 2013, foram sobre o nível de endividamento por região entre cheque pré-datado, cartões de crédito, carnês de lojas, empréstimos pessoal, prestações de carro e seguros. A região na qual as famílias apresentaram melhor percepção em relação ao seu nível de endividamento foi a região Centro-Oeste, onde se observou a maior proporção de famílias pouco endividadas. Nessa Região, 8,5\% das famílias disseram estar muito endividadas, $13,4 \%$ estão mais ou menos endividadas, $47,1 \%$, pouco endividadas e 30,7\% declararam não ter dívidas desse tipo. A região Sul foi aquela na qual as famílias reportaram a pior percepção em relação a seu endividamento. Nessa região, das famílias, $16,3 \%$ disseram estar muito endividadas, enquanto 35,3\%, estar mais ou menos endividadas e $22,2 \%$, pouco endividadas.

A Tabela 2.7 mostra o nível de endividamento por região em dezembro de 2013. A região na qual as famílias apresentaram melhor percepção em relação ao seu nível de endividamento foi a região Centro-Oeste, onde se observou a maior proporção de famílias pouco endividadas. Nessa região, 8,5\% das famílias disseram estar muito endividadas, 13,4\%, mais ou menos endividadas, $47,1 \%$, pouco endividadas e $30,7 \%$ declararam não ter dívidas desse tipo. A região Sul foi aquela na qual as famílias reportaram a pior percepção em relação 
a seu endividamento: $16,3 \%$ das famílias nessa região disseram estar muito endividadas, enquanto $35,3 \%$ disseram estar mais ou menos endividadas e $22,2 \%$ pouco endividadas.

Tabela 2.7 - Nível de endividamento - dezembro de 2013.

\begin{tabular}{lcccccc}
\hline Categoria & Brasil & Norte & Nordeste & Sudeste & Centro-Oeste & Sul \\
\hline Muito endividado & $11,6 \%$ & $7,0 \%$ & $13,6 \%$ & $11,4 \%$ & $8,5 \%$ & $16,3 \%$ \\
\hline Mais ou menos endividado & $24,6 \%$ & $39,3 \%$ & $22,1 \%$ & $23,9 \%$ & $13,4 \%$ & $35,3 \%$ \\
\hline Pouco endividado & $26,0 \%$ & $22,9 \%$ & $26,1 \%$ & $22,3 \%$ & $47,1 \%$ & $22,2 \%$ \\
\hline Não tem dívidas desse tipo & $37,4 \%$ & $30,4 \%$ & $38,1 \%$ & $42,0 \%$ & $30,7 \%$ & $26,1 \%$ \\
\hline Não sabe & $0,3 \%$ & $0,3 \%$ & $0,1 \%$ & $0,4 \%$ & $0,2 \%$ & $0,1 \%$ \\
\hline Não respondeu & $0,1 \%$ & $0,1 \%$ & $0,0 \%$ & $0,1 \%$ & $0,1 \%$ & $0,0 \%$ \\
\hline Fonte: PEIC/CNC 2013. & & & & &
\end{tabular}

A Tabela 2.8 mostra o nível de endividamento por região entre cheque pré-datado, cartões de crédito, carnês de lojas, empréstimos pessoal, prestações de carro e seguros em dezembro de 2013. A mesma pesquisa mostra que, em dezembro de 2013, o cartão de crédito foi a modalidade mais apontada pelas famílias brasileiras endividadas entre seus principais tipos de dívida, $76,4 \%$ do total, seguida por carnês, $16,9 \%$ e, em terceiro lugar, o financiamento de carro, $12,6 \%$. Na comparação entre as regiões, destaca-se:

- Cartão de crédito: foi a modalidade de financiamento mais citada pelas famílias entre seus principais tipos de dívida em todas as regiões. A região Nordeste se destaca com a maior proporção de famílias apontando ter dívidas no cartão $(81,7 \%)$. Na região Sul, observou-se a menor proporção (74\%).

- Carnês: é a segunda modalidade de endividamento mais citada pelas famílias endividadas entre as regiões, como exceção de região Sul, que apresentou a menor proporção (citada por apenas 10,6\% das famílias endividadas) e a região Sudeste. Destaca-se a região Norte, onde $45,8 \%$ das famílias citaram essa modalidade entre seus principais tipos de dívida, a maior proporção entre as regiões.

- Financiamento de carro e financiamento de casa: a maior incidência de famílias com dívidas que citaram essa modalidade foi a região Centro-Oeste, com respectivamente $23,3 \%$ e $9,3 \%$ do total. A menor foi a região Nordeste, com 3,8\% e 2,5\% do total. 
Tabela 2.8 - Tipo de dívida - dezembro de 2013 .

\begin{tabular}{lcccccc}
\hline Tipo & Brasil & Norte & Nordeste & Sudeste & Centro-Oeste & Sul \\
\hline Cartão de crédito & $76,4 \%$ & $74,2 \%$ & $81,7 \%$ & $75,0 \%$ & $75,6 \%$ & $74,0 \%$ \\
\hline Cheque especial & $6,2 \%$ & $2,0 \%$ & $2,6 \%$ & $7,2 \%$ & $14,0 \%$ & $4,6 \%$ \\
\hline Cheque pré-datado & $1,8 \%$ & $1,0 \%$ & $0,7 \%$ & $1,8 \%$ & $5,6 \%$ & $1,1 \%$ \\
\hline Crédito consignado & $4,8 \%$ & $7,0 \%$ & $3,0 \%$ & $5,2 \%$ & $8,0 \%$ & $1,6 \%$ \\
\hline Crédito pessoal & $7,9 \%$ & $9,5 \%$ & $4,2 \%$ & $9,6 \%$ & $10,3 \%$ & $3,0 \%$ \\
\hline Carnês & $16,9 \%$ & $45,8 \%$ & $11,5 \%$ & $13,1 \%$ & $27,3 \%$ & $10,6 \%$ \\
\hline Financiamento de carro & $12,6 \%$ & $9,8 \%$ & $3,8 \%$ & $14,8 \%$ & $23,3 \%$ & $12,6 \%$ \\
\hline Financiamento de casa & $6,7 \%$ & $3,7 \%$ & $2,5 \%$ & $8,7 \%$ & $9,3 \%$ & $5,4 \%$ \\
\hline Outras dívidas & $3,2 \%$ & $3,3 \%$ & $7,6 \%$ & $1,0 \%$ & $4,7 \%$ & $2,1 \%$ \\
\hline Não sabe & $0,1 \%$ & $0,0 \%$ & $0,1 \%$ & $0,1 \%$ & $0,1 \%$ & $0,1 \%$ \\
\hline Não respondeu & $0,2 \%$ & $1,4 \%$ & $0,2 \%$ & $0,1 \%$ & $0,1 \%$ & $0,0 \%$ \\
\hline Fonte: PEIC/CNC 2013. & & & & & & \\
\hline
\end{tabular}

A Tabela 2.9 mostra o comprometimento médio e a parcela da renda comprometida com dívida das famílias em dezembro de 2013, no Brasil e por região. O comprometimento médio das famílias endividadas foi de 30,2\% da renda mensal. Ademais 21,8\% das famílias endividadas relataram ter mais da metade da renda comprometida com o pagamento de dívidas. A parcela média da renda comprometida com dívidas, na comparação regional, foi maior entre as famílias do Norte, com $33,8 \%$ da renda mensal. Na região Sudeste, a parcela média comprometida com dívidas foi a menor, na comparação regional, com $27,8 \%$ da renda.

Tabela 2.9 - Parcela da Renda comprometida com dívida (dentre os endividados) - dezembro de 2013

\begin{tabular}{lcccccc}
\hline Faixa & Brasil & Norte & Nordeste & Sudeste & Centro-Oeste & Sul \\
Menos de $10 \%$ & $22,2 \%$ & $15,4 \%$ & $16,2 \%$ & $28,0 \%$ & $16,9 \%$ & $19,4 \%$ \\
De $11 \%$ a $50 \%$ & $50,1 \%$ & $49,7 \%$ & $43,0 \%$ & $49,5 \%$ & $56,7 \%$ & $63,2 \%$ \\
Superior a 50\% & $21,8 \%$ & $32,8 \%$ & $30,0 \%$ & $16,6 \%$ & $23,6 \%$ & $16,0 \%$ \\
Parcela média & $30,2 \%$ & $33,8 \%$ & $33,3 \%$ & $27,8 \%$ & $31,7 \%$ & $29,6 \%$ \\
\hline
\end{tabular}

Fonte: PEIC/CNC 2013

Como destaque dos dados da Pesquisa de Endividamento e Inadimplência do Consumidor (PEIC) divulgada pela CNC em 2013 o Sudeste continuou sendo a região com o menor percentual de famílias endividadas (56\% das famílias). Apesar de deter o maior volume de crédito do sistema Financeiro Nacional - 48\% das operações acima de R\$1 mil em outubro de 2013, segundo do Banco Central do Brasil - é na região Sudeste onde o saldo 
dessas operações tem apresentado a menor taxa de crescimento anual, 15,7\%, ante a média brasileira de $17,0 \%$ no mesmo mês de referência.

A região Sudeste também apresenta o menor patamar de famílias, inadimplentes, juntamente com o Centro-Oeste. Nessas regiões $18,8 \%$ e $18,9 \%$ das famílias, respectivamente, relataram ter dívidas ou contas em atraso. O baixo comprometimento de renda das famílias da região Sudeste e o perfil mais favorável do endividamento da região Centro-Oeste, estão relacionados a esse comportamento. Os dados do Banco Central do Brasil mostram que, para as operações acima de $\mathrm{R} \$ 1$ mil, a região Centro-Oeste conta com a segunda menor taxa de inadimplência para as pessoas físicas, com 3,4\% do saldo de crédito em atraso superior a 90 dias e redução de 0,8 pontos percentuais em relação a dezembro de 2012.

O Norte é a região com a menor taxa de famílias que relataram não ter condições de pagar suas contas ou dívidas em atraso. Muito embora as famílias dessa região se apresentassem otimistas na sua percepção em relação à sua capacidade de pagamento, nessa região observou-se o maior percentual de famílias com contas ou dívidas em atraso. Os dados regionais da oferta de crédito do Banco Central do Brasil também mostram nessa região a maior taxa de inadimplência, juntamente com o Nordeste, em relação às demais regiões $(5,5 \%$ do saldo com atraso superior a 90 dias). No entanto, na região Norte, observa-se uma desaceleração do ritmo de crescimento do saldo das operações de crédito e uma redução da taxa de inadimplência.

A região Sul se destacou como aquela com a maior incidência de famílias endividadas: 76,0\% das famílias da região Sul disseram ter dívidas em 2013 e 16,3\% delas relataram estar muito endividadas em dezembro de 2013. Adicionalmente, $8,8 \%$ disseram não ter condições de pagar suas dívidas ou contas em atraso, o maior patamar entre as regiões geográficas. Apesar de contar com o maior pessimismo em relação às suas dívidas, na região Sul observou-se o terceiro menor percentual de famílias com dívidas em atraso. Adicionalmente, essa região foi a única onde se observou redução no endividamento em 2013. As melhores condições no mercado de trabalho e a desaceleração da taxa de crescimento do crédito ajudam explicar esse resultado. Também é na região Sul onde os dados do Banco Central do Brasil para operações de crédito mostraram a menor taxa de inadimplência, correspondente a 3,2\% até outubro. 


\section{CAPÍTULO 3}

\section{O ENDIVIDAMENTO DO SERVIDOR PÚBLICO DA UnB}

\section{1. À guisa de introdução}

Acreditamos ter evidenciado o crescimento do acesso ao crédito por parte do brasileiro. Ficou claro, também, que esse maior acesso ao sistema creditício está incrementando o seu nível de endividamento. Não obstante, não existem informações disponíveis em um nível desagregado o suficiente para podermos aprofundar nossa análise sobre o endividamento do servidor público federal brasileiro. Por causa disso fomos obrigados a selecionar uma amostra desses servidores para que pudéssemos empreender uma análise mais detalhada do grau de endividamento existente, principalmente depois do estabelecimento do empréstimo consignado em folha de pagamento.

A amostra por nós selecionada foi composta pelos servidores ativos e inativos da Fundação Universidade de Brasília - FUB. Qual foi o critério para a seleção dessa amostra? A resposta é simples: a disponibilidade de informações com um maior nível de desagregação do que aquela disponível para a população de servidores públicos federais. Estamos conscientes que esse critério de escolha pode ter gerado um viés em nossa análise: o servidor da FUB pode estar mais (ou menos) endividado do que o servidor público federal brasileiro. Essa será uma dúvida que permanecerá até que possamos contar com maiores detalhes sobre endividamento entre diferentes segmentos de empregados no serviço público federal. Neste momento, esses detalhes não estão disponíveis.

Conscientes dessa possível limitação, julgamos que, ainda assim, nossa escolha nos possibilitou um incremento - que será avaliado pelo leitor desta dissertação - no nível de conhecimento hoje existente sobre endividamento do brasileiro, em geral, e do servidor público, em particular. Tivemos o máximo cuidado com as generalizações que fizemos a partir dos resultados obtidos para a nossa amostra. No entanto, esses resultados trouxeram alguns aspectos novos para o entendimento das causas do endividamento e do perfil do endividado, aspectos esses que têm sido pouco explorados na literatura sobre o assunto, que foi analisada no Capítulo 1.

\subsection{Características Gerais da Amostra}

O número total de servidores da FUB é de 7.241 servidores com base nas informações de dezembro de 2014. Desses, 3.200 são docentes e 4.041 são servidores técnico- 
administrativos. Esses números estão estáveis desde 2013, como evidenciado pelos Gráficos 3.1 a 3.4 para os técnico-administrativos. Em termos de nível de escolaridade (que determina suas classes funcionais), há um certo predomínio de servidores com ensino superior completo e com nível médio, ambos com participação próxima a 37\% cada.

Gráfico 3.1 - Quantidade de servidores técnico-administrativos da FUB da folha de pagamento do mês de janeiro de 2013, divididos por classe e seus respectivos percentuais.

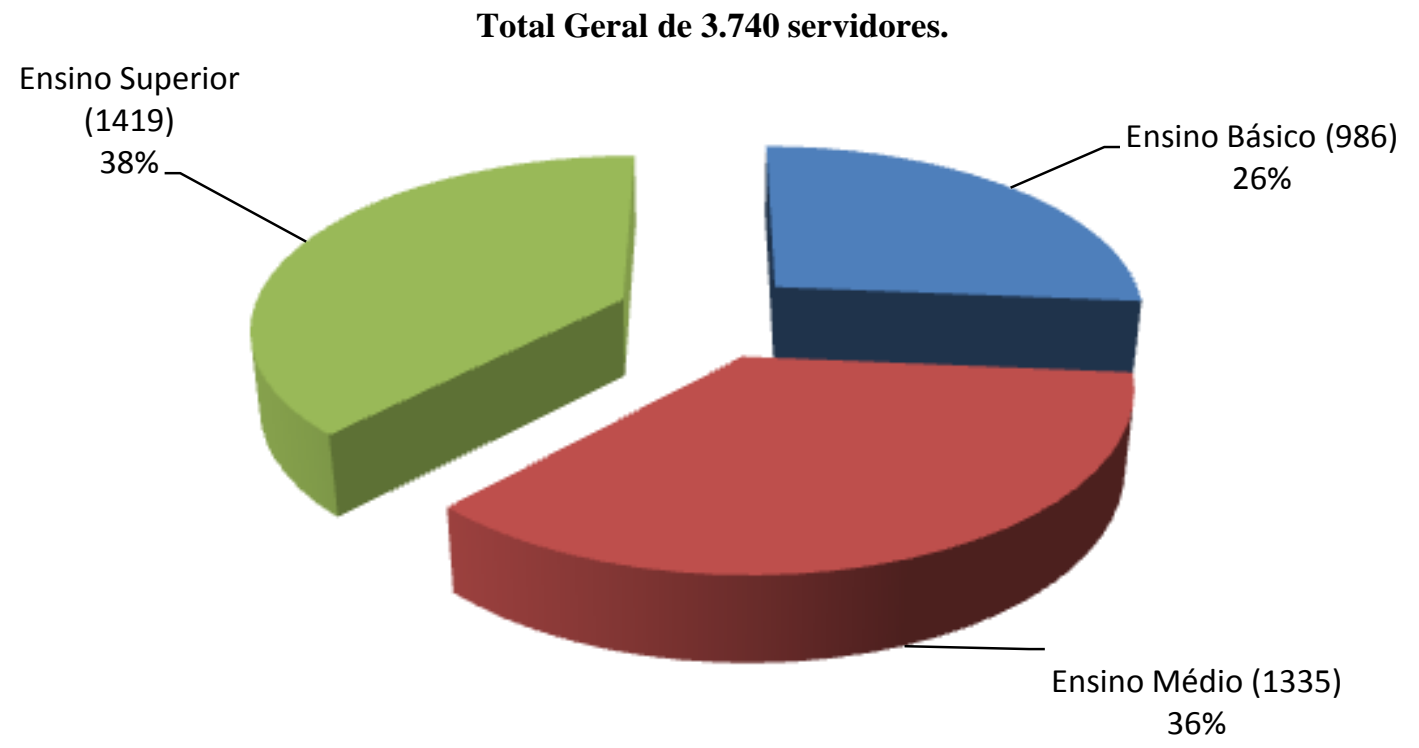

Fonte: SIAPE/DGP/CPD

Gráfico 3.2 - Quantidade de servidores técnico-administrativos da FUB da folha de pagamento do mês de dezembro de 2013, divididos por classe e seus respectivos percentuais.

Total Geral de 3.715 servidores.

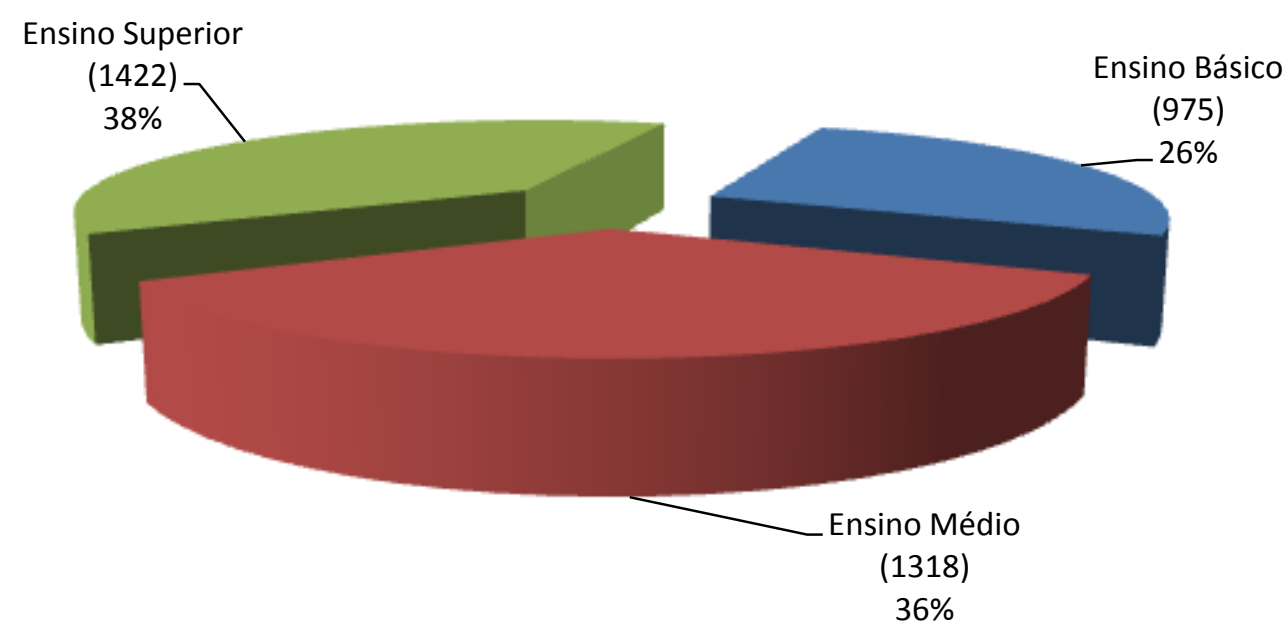

Fonte: SIAPE/DGP/CPD - elaborada pelo pesquisador. 
Gráfico 3.3 - Quantidade de servidores técnico-administrativos da FUB da folha de pagamento do mês de janeiro de 2014, divididos por classe e seus respectivos percentuais.

Total Geral de 3.740 servidores.

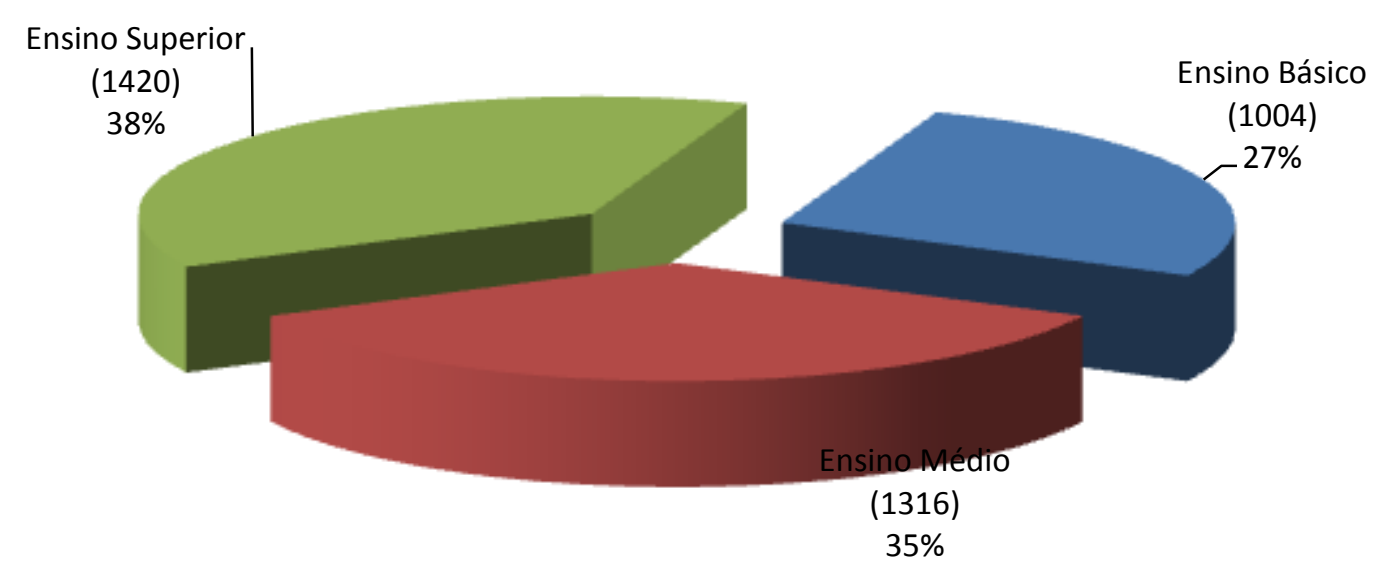

Fonte: SIAPE/DGP/CPD - elaborada pelo pesquisador.

Gráfico 3.4 - Quantidade de servidores técnico-administrativos da FUB da folha de pagamento do mês de dezembro de 2014, divididos por classe e seus respectivos percentuais.

Total Geral de 4.041 servidores.

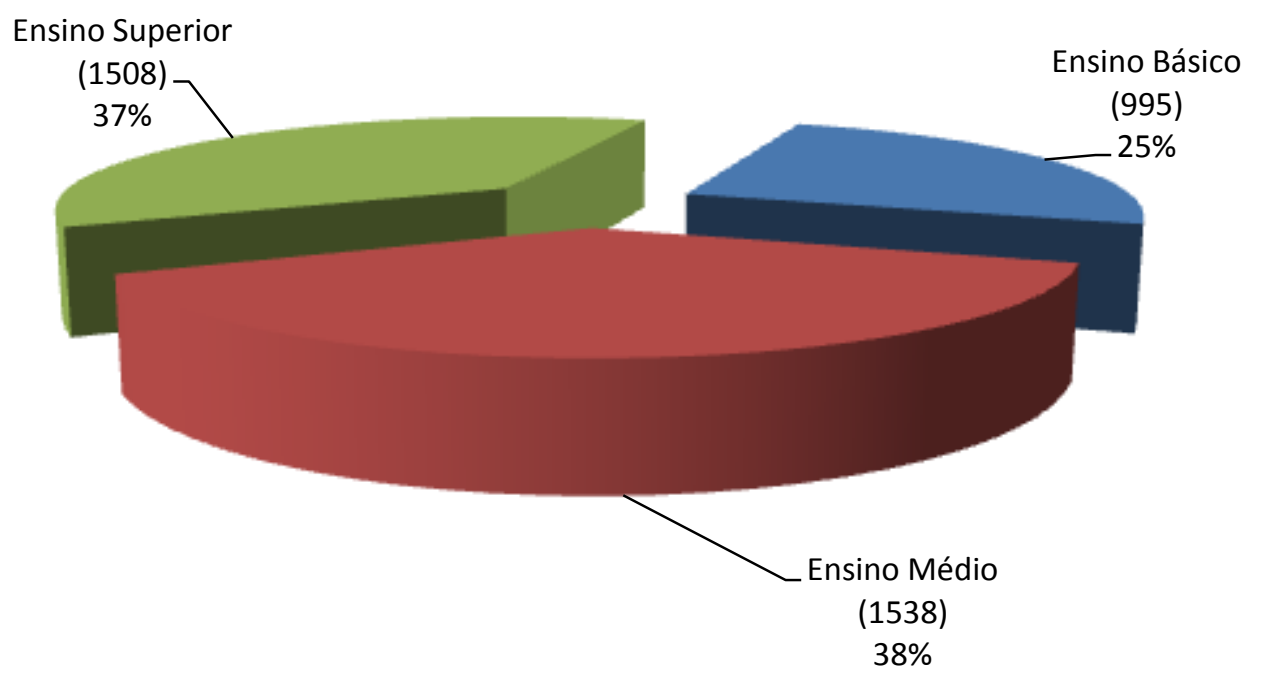

Fonte: SIAPE/DGP/CPD - elaborada pelo pesquisador.

Para os servidores docentes, todos detentores de pelo menos o diploma de curso superior, a classificação por classes é apresentada nos Gráficos 3.5 a 3.8 para os anos de 2013 e 2014. Entre janeiro de 2013 e dezembro de 2014 houve um pequeno aumento no número 
total de servidores docentes (de 3.007 para 3.200). A classe com maior número de servidores docentes é a de Professor Adjunto, com $60 \%$ do total ao final do período analisado (dezembro de 2014). A classe com menor número de professores é a de Docente Auxiliar, com $4 \%$ do total em dezembro de 2014.

Gráfico 3.5 - Quantidade de servidores docentes da FUB da folha de pagamento do mês de janeiro de 2013, divididos por classe e seus respectivos percentuais.

Total Geral de 3.007 servidores.

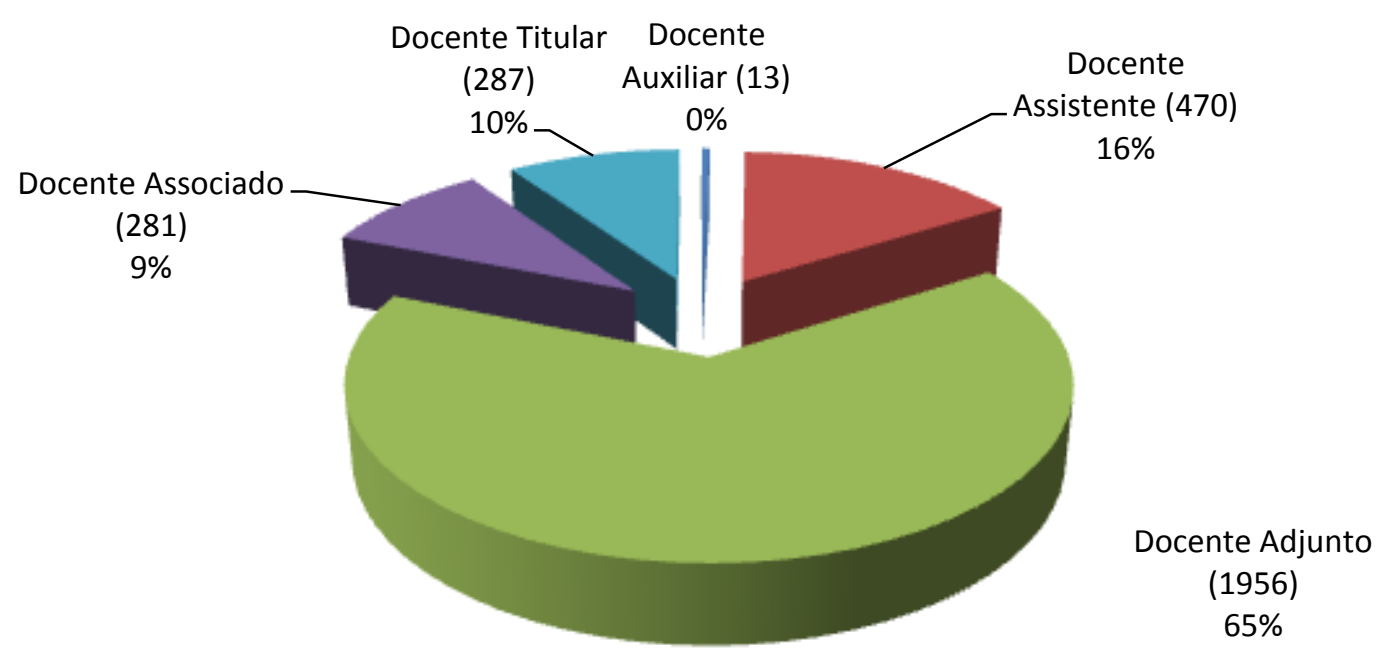

Fonte: SIAPE/DGP/CPD - elaborada pelo pesquisador.

Gráfico 3.6 - Quantidade de servidores docentes da folha de pagamento do mês de dezembro de 2014, divididos por classe e seus respectivos percentuais. 
Total Geral de 3.138 servidores.

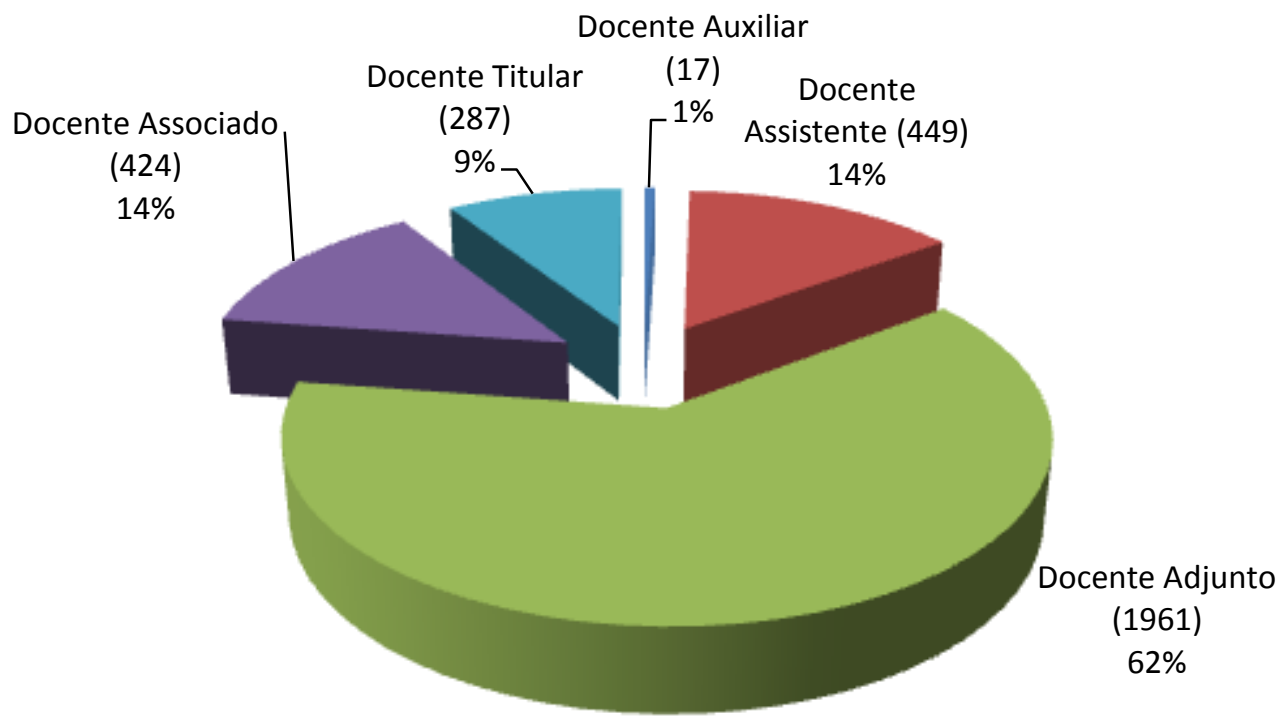

Fonte: SIAPE/DGP/CPD - elaborada pelo pesquisador.

Gráfico 3.7 - Quantidade de servidores docentes da FUB da folha de pagamento do mês de janeiro de $\mathbf{2 0 1 4}$, divididos por classe e seus respectivos percentuais.

\section{Total Geral de 3.137 servidores.}

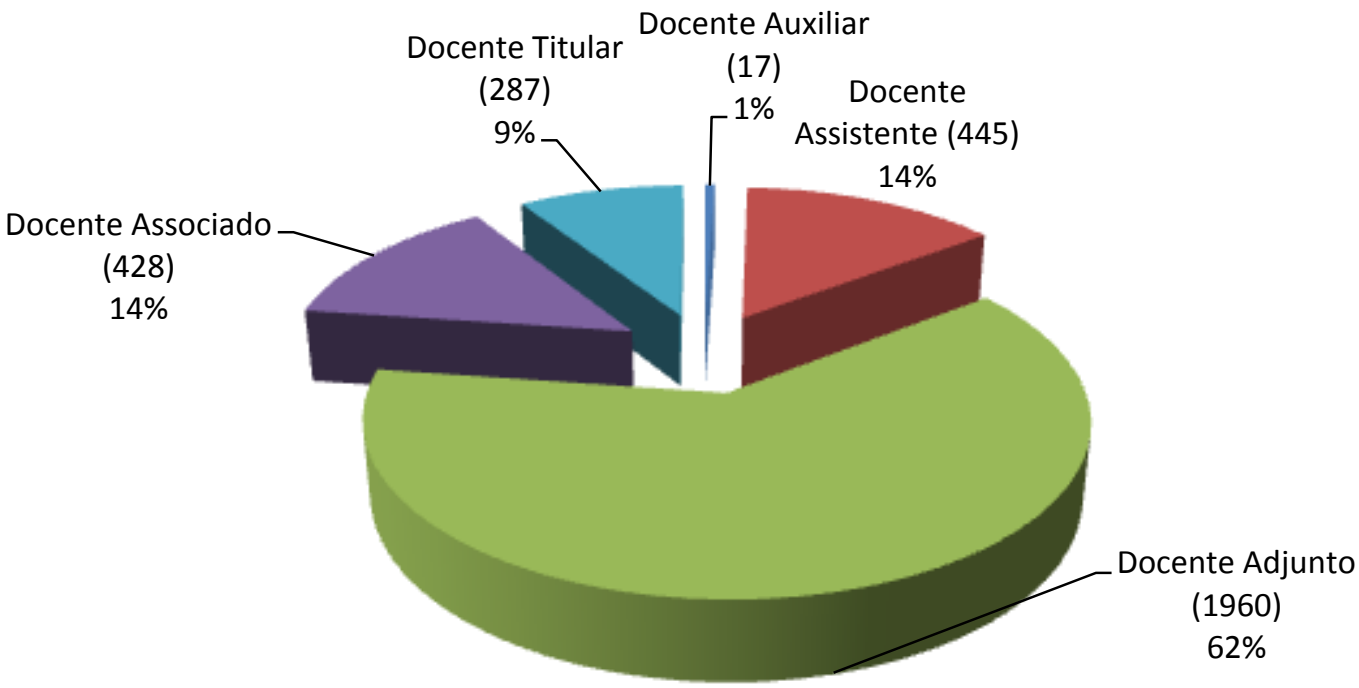

Fonte: SIAPE/DGP/CPD - elaborada pelo pesquisador.

Gráfico 3.8 - Quantidade de servidores docentes da FUB da folha de pagamento do mês de dezembro de 2014, divididos por classe e seus respectivos percentuais. 
Total Geral de 3.200 servidores.

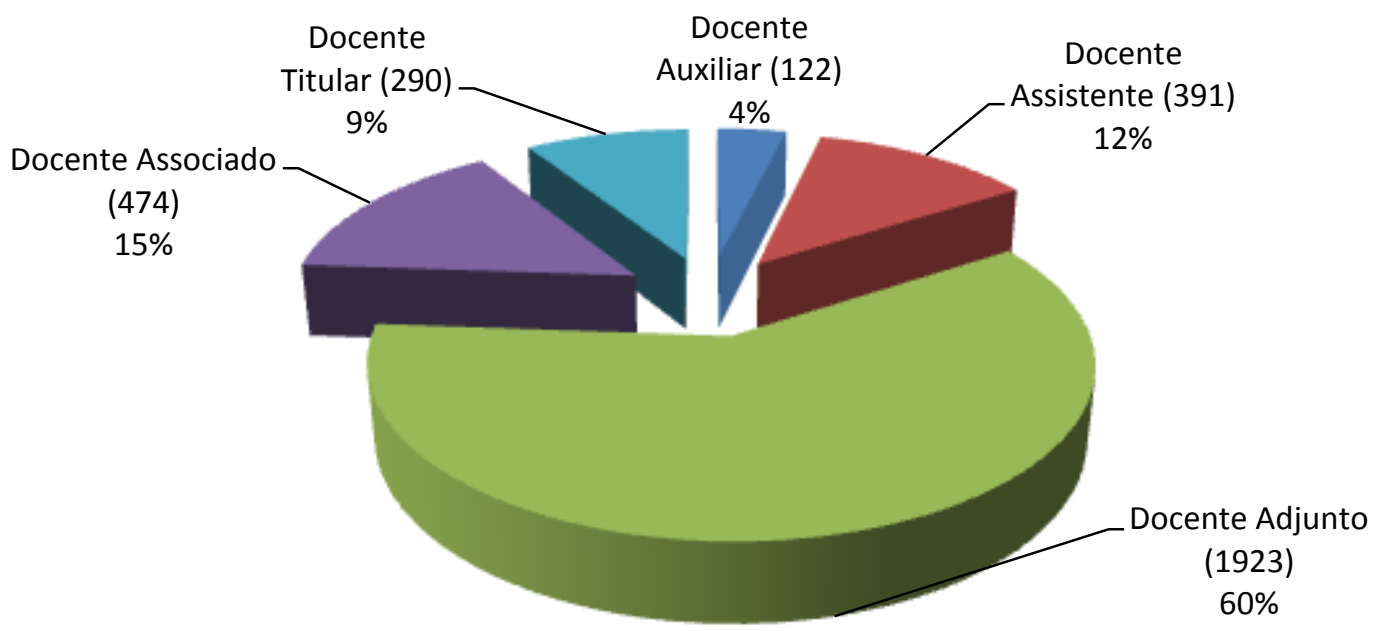

Fonte: SIAPE/DGP/CPD - elaborada pelo pesquisador.

Com intuito de obter confiabilidade das fontes internas da FUB, estruturamos as Tabelas 3.1 e 3.2 que, com dados de fonte distinta da dos Gráficos anteriores, confirmam os números anteriormente apresentados. Essas tabelas mostram, respectivamente, as quantidades de servidores técnico-administrativos e de docentes nas folhas de pagamentos de janeiro e dezembro de 2013 e de janeiro e dezembro de 2014 por classe. Fica evidente a consistência das informações de diferentes fontes da FUB.

Tabela 3.1 - Quantidade de servidores técnicos da FUB das folhas de pagamento dos meses de janeiro e dezembro dos anos de 2013 e 2014 , por classe.

\begin{tabular}{lcccccc}
\hline Classe & Jan/2013 & Dez/2013 & Jan/2014 & Dez/2014 & Jan 2013/2014 - Dez 2013/2014 \\
\hline Ensino Básico & 986 & 975 & 1.004 & 995 & 1,8 & 2,0 \\
Ensino Médio & 1.335 & 1.318 & 1.316 & 1.538 & $-1,5$ & 16,7 \\
Ensino Superior & 1.419 & 1.422 & 1.420 & 1.508 & 0,0 & 6,0 \\
Total & 3.740 & 3.715 & 3.740 & 4.041 & 0,0 & 8,8 \\
\hline Fonte: SIAPE/DGP/CPD - elaborada pelo pesquisador & & & &
\end{tabular}

Tabela 3.2 - Quantidade de servidores docentes da FUB das folhas de pagamento dos meses de janeiro e dezembro dos anos de 2013 e 2014 , por classe. 


\begin{tabular}{lcccccc} 
Classe & Jan/2013 & Dez/2013 & Jan/2014 & Dez/2014 & Jan 2013/2014 - Dez 2013/2014 \\
\hline Docente Auxiliar & 13 & 17 & 17 & 122 & 30,8 & 17,6 \\
Docente Assistente & 470 & 449 & 445 & 391 & $-5,6$ & $-4,8$ \\
Docente Adjunto & 1.956 & 1.961 & 1.960 & 1.923 & 0,2 & $-2,0$ \\
Docente Associado & 281 & 424 & 428 & 474 & 52,3 & 10,7 \\
Docente Titular & 287 & 287 & 287 & 290 & 0,0 & 1,5 \\
Total & 3.007 & 3.138 & 3.137 & 3.200 & 4,4 & 2,0 \\
\hline
\end{tabular}

Fonte: SIAPE/DGP/CPD - elaborada pelo pesquisador.

\subsection{Panorama geral do endividamento do servidor da FUB}

Nosso detalhamento sobre o nível de endividamento do servidor público da FUB será limitado aos anos de 2013 e 2014. Esses são os anos com informações disponíveis. A fonte básica dos dados aqui apresentados são os Relatórios de Empréstimos Consignados concedidos aos servidores ativos e inativos da Fundação Universidade de Brasília - FUB. Esses Relatórios não permitem a identificação individual dos tomadores de empréstimos, nos fornecendo valores absolutos de empréstimos consignados dos servidores docentes e técnicoadministrativos divididos por classe. De outras fontes internas da FUB, obtivemos o valor da folha de pagamento dos diferentes tipos e níveis de servidores, para os mesmos anos de 2013 e 2014.

Iniciamos nossa análise exatamente pelos valores das folhas de pagamento da FUB. Na Tabela 3.3 resumimos a evolução da quantidade de servidores técnico-administrativos ativos e inativos e dos valores totais das folhas de pagamentos, por classes, para os meses de dezembro de 2013 e dezembro de 2014. Para uma melhor visualização das mudanças ocorridas nos valores das folhas de pagamento, estruturamos o Gráfico 3.9. De maneira análoga, a Tabela 3.4 mostra a evolução das quantidades de servidores e os montantes das folhas de pagamentos para o caso de docentes ativos e inativos, também para os meses de dezembro de 2013 e de 2014, divididos por classe. Já o Gráfico 4.10 mostra a evolução dos montantes das folhas de pagamentos desses dois meses para os servidores docentes ativos e inativos da FUB, divididos por classe.

Diversos aspectos relevantes podem ser ressaltados a partir dos dados resumidos nessas tabelas e gráficos. Em primeiro lugar, há um crescimento no valor monetário total das folhas de pagamento dos servidores técnico-administrativos e dos servidores docentes (ativos e inativos) entre os dois períodos. No caso dos técnico-administrativos esse crescimento alcançou $16,6 \%$ em termos nominais; para os docentes esse crescimento se aproximou de 
12,5\%. Esses incrementos foram superiores à taxa de inflação 2014: $6.41 \%$ no período e maiores do que o crescimento no número de técnico-administrativos e de docentes no mesmo período ( $8,8 \%$ e $2,0 \%$, respectivamente). Assim, se houve aumento do endividamento entre os funcionários públicos da FUB (ver adiante), esse aumento ocorreu em um período de crescimento da remuneração total em termos reais e médios.

Tabela 3.3 - Quantidade de servidores técnicos da FUB e valor total dos vencimentos constantes das folhas de pagamentos dos meses de dezembro de 2013 e de 2014. Divididos por classes. Valores em reais correntes.

\begin{tabular}{lcccccc}
\hline Classe & \multicolumn{1}{l}{ Dez/2013 } & Montante em R\$ & - Dez/2014 & - Montante em R\$ & Servidores & - Montante \\
\hline Ensino Básico & 975 & $2.158 .596,84$ & 995 & $2.359 .353,91$ & 2,0 & 9,3 \\
Ensino Médio & 1.318 & $3.784 .760,05$ & 1.538 & $4.632 .203,87$ & 16,7 & 22,4 \\
Ensino Superior & 1.422 & $6.374 .838,10$ & 1.508 & $7.365 .687,28$ & 6,0 & 15,5 \\
Total & 3.715 & $12.318 .194,99$ & 4.041 & $14.357 .245,06$ & 8,8 & 16,6 \\
\hline Fonte: SIAPE/DGP/CPD - elaborada pelo pesquisador.
\end{tabular}

Gráfico 3.9 - Montante da folha de pagamento dos servidores técnicos dos meses de dezembro de 2013 e 2014, divididos por classes. Valores em reais correntes.

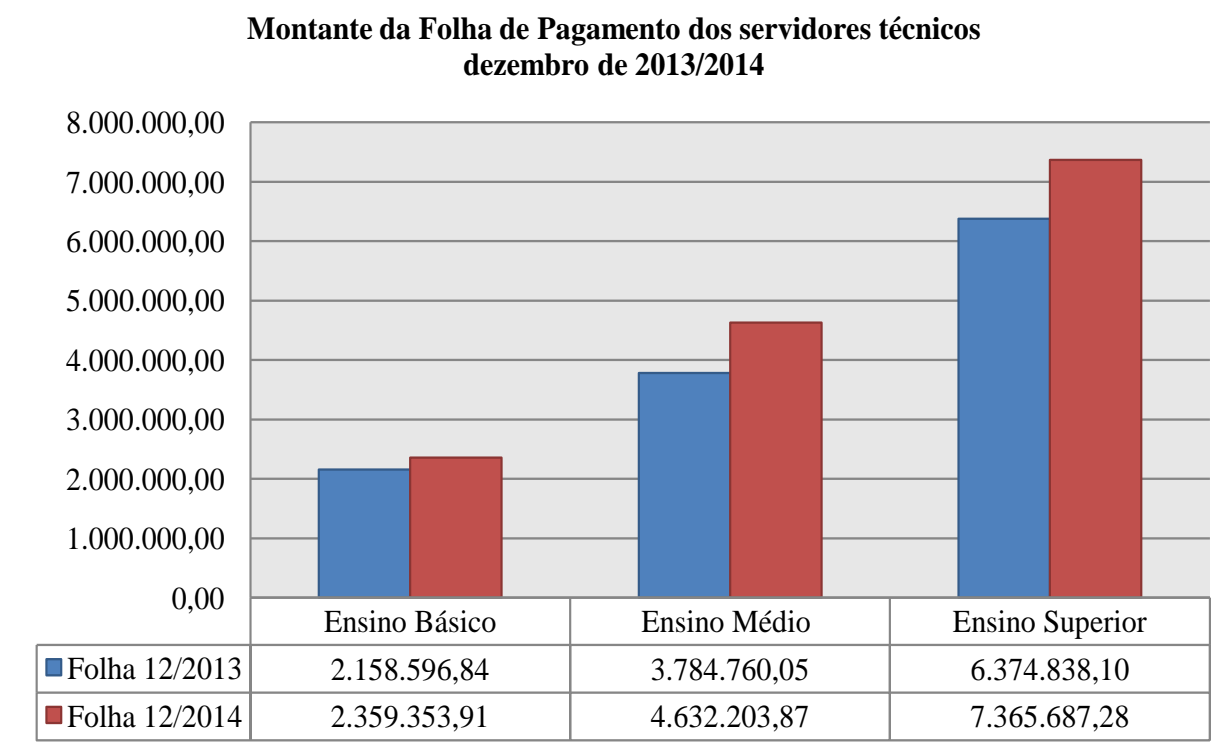

Fonte: SIAPE/DGP/CPD - elaborado pelo pesquisador

Um segundo aspecto surge da análise das diferentes classes dos servidores federais da FUB. Entre os técnico-administrativos, o salário médio nominal cresceu em todas as classes 
entre dezembro de 2013 e dezembro de 2014, uma vez que o valor da folha salarial cresceu mais do que o número de servidores em cada classe. No entanto, o maior crescimento de salário médio nominal foi observado entre os técnico-administrativos que tem o curso superior completo. Nessa classe, o valor total da folha de pagamento cresceu mais de $15 \%$ contra um crescimento no número de servidores de apenas $6 \%$. Nesse contexto, era nossa expectativa que a busca por crédito consignado teria sido maior entre os técnicoadministrativo com ensino básico do que entre os servidores das demais classes. Vamos ver adiante se nossa expectativa se confirmou.

Análise semelhante pode ser realizada para os servidores docentes. Entre as cinco classes contempladas, os maiores crescimentos de salários médios foram observados para as três classes superiores (adjunto, associado e titular). Em particular, destaca-se os professores adjuntos para os quais o número de professores decresceu $2 \%$ no período analisado, enquanto que o valor da folha de pagamento para a classe experimentou um incremento de $9 \%$ em um ano. Crescimento nominal significativo no valor da folha de pagamento (6\%) também foi observado na classe de professor titular, para a qual o crescimento no número de professores foi muito pequeno (apenas $3 \mathrm{em}$ um ano, perto de $1 \%$ em relação à quantidade existente em dezembro de 2013. Podemos, então, manifestar nossa expectativa de que a busca por crédito consignado tenha sido maior entre os docentes auxiliares e os docentes assistentes, pois esses experimentaram um incremento nominal menor entre final de 2013 e 2014.

Tabela 3.4 - Quantidade de servidores docentes da FUB e valor total dos vencimentos constantes das folhas de pagamentos do mês de dezembro de 2013 e 2014. Divididos por classe. Valores em reais correntes.

Variação \% - Variação \%

\begin{tabular}{lcccccc}
\hline Classe & \multicolumn{2}{c}{ Dez/2013 } & - Montante em R\$ - Dez/2014 & - Montante em R\$ & Servidor & - Montante \\
\hline Docente Auxiliar & 17 & $59.170,46$ & 122 & $671.259,47$ & 17,6 & 34,4 \\
Docente Assistente & 449 & $1.617 .129,39$ & 391 & $1.532 .930,77$ & $-14,8$ & $-5,5$ \\
Docente Adjunto & 1.961 & $8.233 .582,43$ & 1.923 & $8.984 .225,49$ & $-2,0$ & 9,1 \\
Docente Associado & 424 & $2.651 .503,68$ & 474 & $3.075 .755,95$ & 11,8 & 16,0 \\
Docente Titular & 287 & $2.074 .895,21$ & 290 & $2.202 .636,94$ & 1,0 & 6,1 \\
Total & 3.138 & $14.636 .281,17$ & 3.200 & $16.466 .808,62$ & 2,0 & 12,5 \\
\hline Fonte: SIAPE/DGP/CPD - elaborada pelo pesquisador. & & &
\end{tabular}

Gráfico 3.10 - Montante da folha de pagamento dos servidores docentes do mês de dezembro dos anos de 2013 e 2014, divididos por classe. 


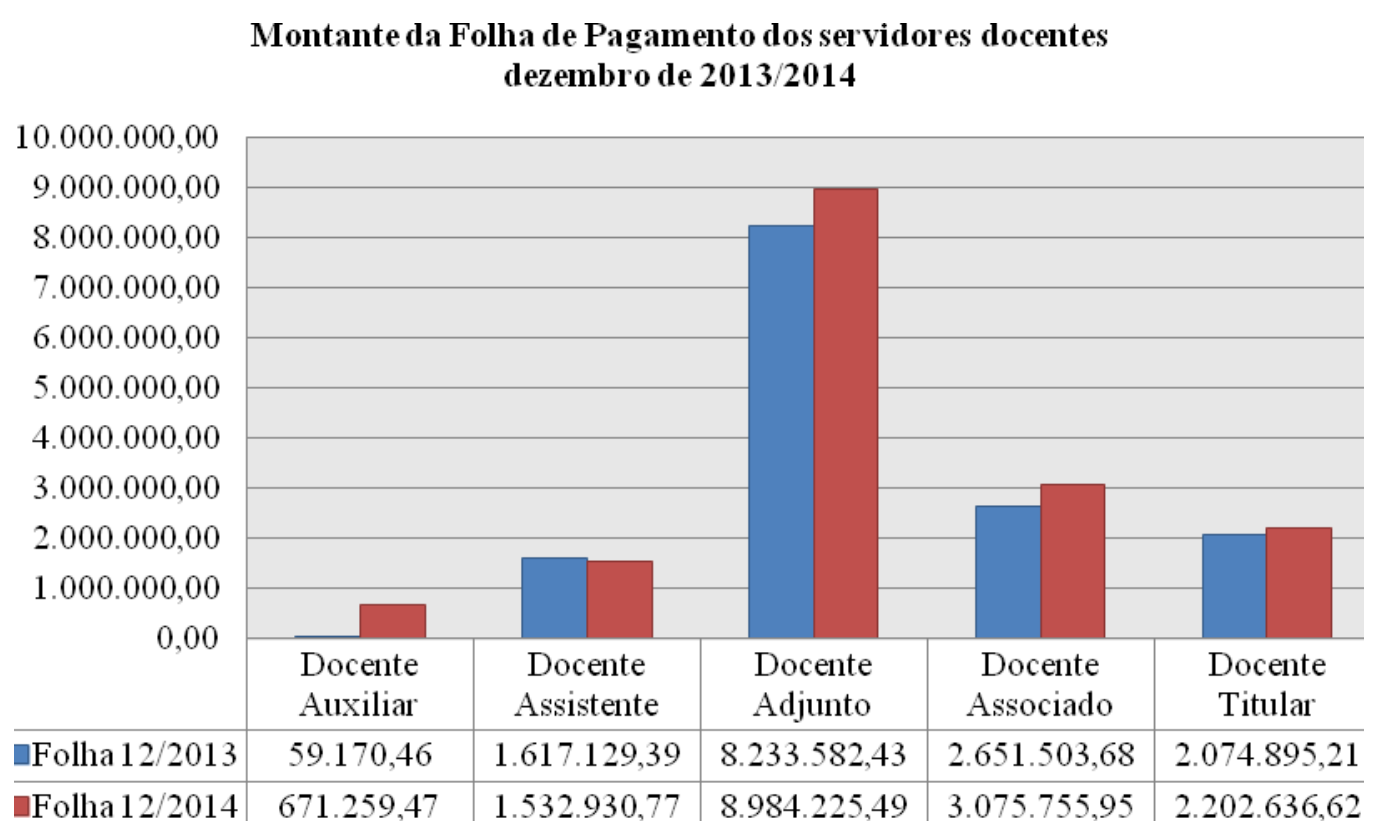

Fonte: SIAPE/DGP/CPD - elaborado pelo pesquisador

Os gráficos 3.11 e 3.12 mostram os montantes das folhas de pagamento do mês de dezembro de 2013 e de 2014 e os montantes dos empréstimos consignados nos anos de 2013 e de 2014 dos servidores técnico-administrativos ativos e inativos da FUB, divididos por classe. Na Tabela 3.5 resumimos a evolução do montante em reais correntes dos empréstimos consignados concedidos aos servidores técnico-administrativos ativos e inativos da FUB, por classes, nos anos de 2013 e 2014.

Diversas informações relevantes podem ser ressaltadas a partir dos dados resumidos nessa tabela e nos gráficos. Há um crescimento no montante dos empréstimos consignados e no montante das folhas de pagamentos para todas as três classes. Para o Ensino Básico a folha de pagamento (tabela 3.3) cresceu de dezembro de 2013 para dezembro de 2014 em 9,3\% ante 6,3\% do montante do empréstimo consignado de 2013 para 2014 (tabela 3.5). Para o Ensino Médio no mesmo período a folha cresceu em 22,4\% (tabela 3.3) ante 11,4\% o montante do empréstimo consignado (tabela 3.5). Para o Ensino Superior, a folha cresceu em 15,4\% (tabela 3.3) ante 11,6\% o montante do empréstimo consignado (tabela 3.5). Na comparação entre as classes, destaca-se o maior crescimento na folha de pagamento para a classe Ensino Médio (22,4\%), enquanto o Ensino Superior teve maior crescimento do montante de empréstimo consignado (15,3\%). Já no total geral a folha de pagamento cresceu 16,6\% (tabela 3.3 ) ante $11,6 \%$ do montante do empréstimo consignado. 
Gráfico 3.11 - Montante da folha de pagamento dos servidores técnicos do mês de dezembro de 2013 e o montante do empréstimo consignado de 2013, divididos por classe.

Empréstimo Consignado dos servidores técnicos 2013

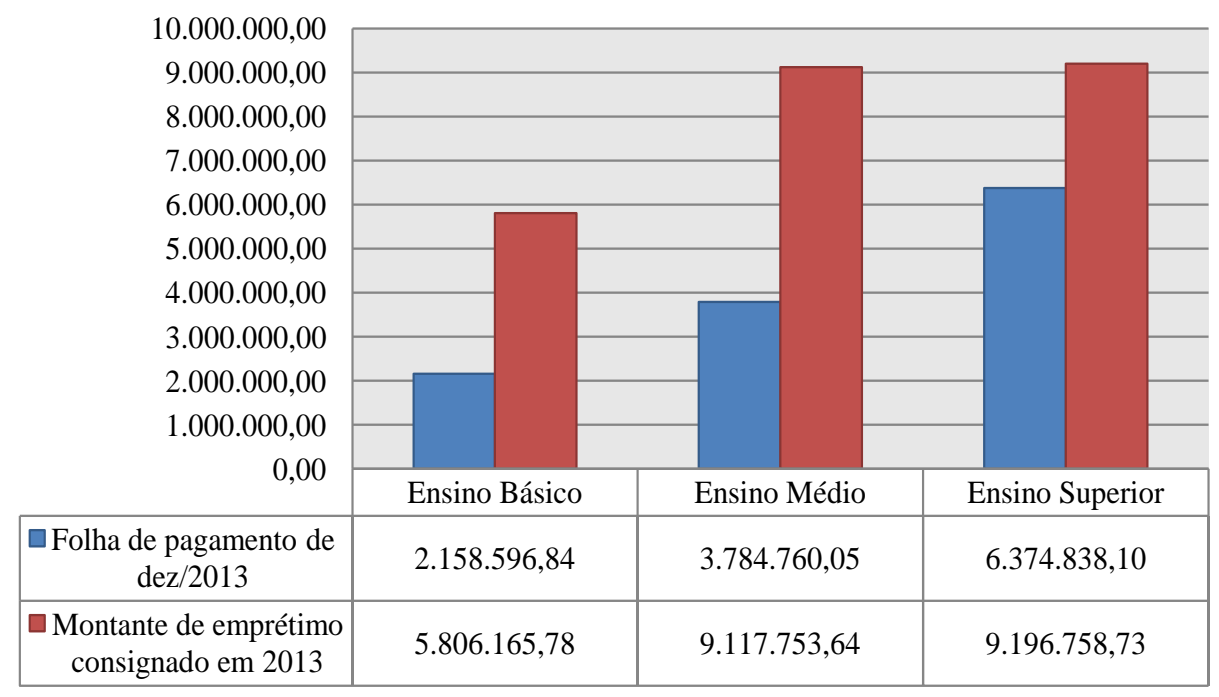

Fonte: SIAPE/DGP/CPD - Elaborado pelo pesquisador

Gráfico 3.12 - Montante da folha de pagamento dos servidores técnicos do mês de dezembro de 2014 e o montante do empréstimo consignado de 2014, divididos por classe.

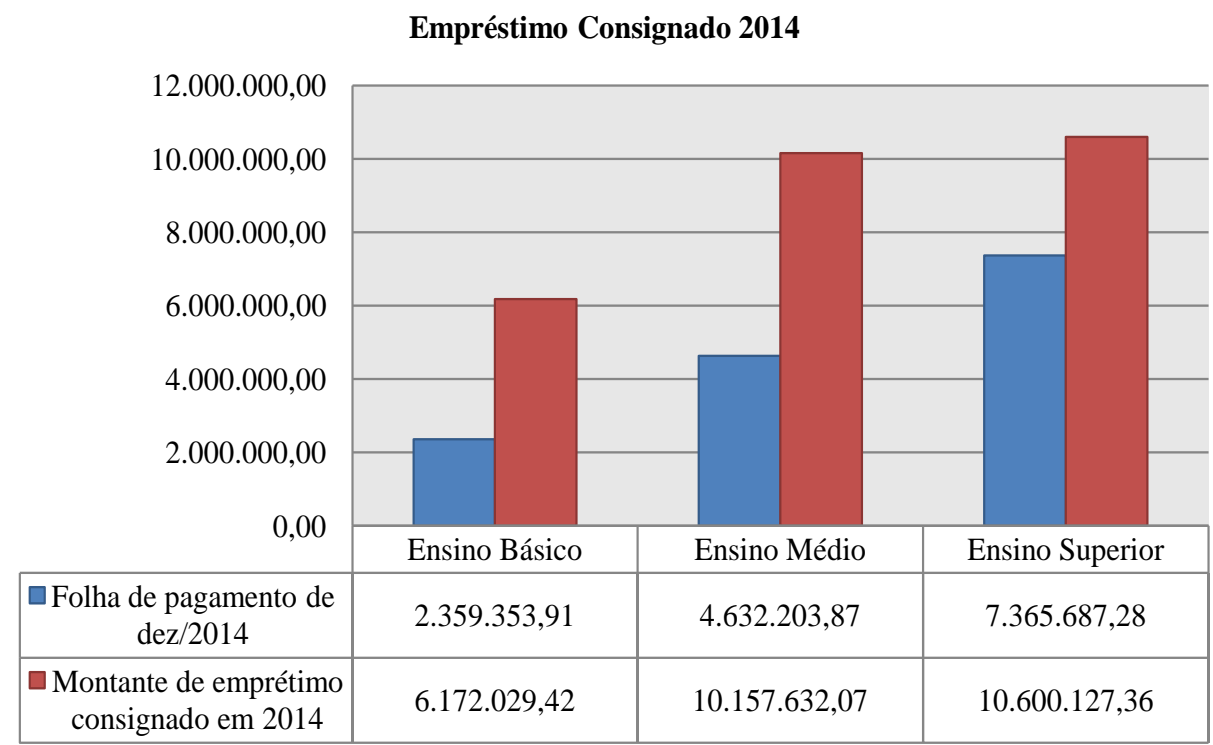

Fonte: SIAPE/DGP/CPD - Elaborado pelo pesquisador

Tabela 3.5 - Montante de empréstimo concedido aos servidores técnico-administrativos (ativos e inativos) em 2013 e 2014, divididos por classe e variação \% 2013/2014. 


\begin{tabular}{lccc} 
Classe & Montante R\$ / 2013 & Montante R\$ / 2014 & \\
\hline Ensino Básico & $5.806 .165,78$ & $6.172 .029,42$ & 6,3 \\
Ensino Médio & $9.117 .753,64$ & $10.157 .632,07$ & 11,4 \\
Ensino Superior & $9.196 .758,73$ & $10.600 .127,36$ & 15,2 \\
Total & $24.120 .678,15$ & $26.929 .788,85$ & 11,6 \\
\hline Fonte: SIAPE/DGP/CPD - elaborada pelo pesquisador.
\end{tabular}

Os gráficos 3.13 e 3.14 mostram os montantes das folhas de pagamento do mês de dezembro de 2013 e de 2014 e os montantes dos empréstimos consignados nos anos de 2013 e de 2014 dos servidores docentes ativos e inativos da FUB, divididos por classe. Na Tabela 3.6 resumimos a evolução do montante em reais correntes dos empréstimos consignados concedidos aos servidores docentes ativos e inativos da FUB, por classes, nos anos de 2013 e 2014. No montante dos empréstimos consignados houve crescimento para todas as classes, com destaque de maior crescimento para os professores auxiliares $(74,6 \%) \mathrm{e}$ o menor crescimento para os professores assistentes (apenas 0,5\%). Uma possível explicação para esse comportamento pode ser encontrada na tabela 3.4 em que no período de dezembro de 2013 a dezembro de 2014 tanto a quantidade de professores auxiliares como o montante da folha de pagamentos desses professores houve crescimento em 17,6\% e 34,4\% respectivamente. Para os professores assistentes houve decréscimo em 14,8\% e 5,5\% na quantidade de professores e no montante da folha de pagamento respectivamente. Nesta mesma linha destaca-se os professores adjuntos para os quais o numero de professores decresceu $2 \%$ a folha de pagamento cresceu em $9,1 \%$ e, paralelamente o montante de empréstimo consignado cresceu em 11,5\%. Já para os professores titulares o numero de professores cresceu apenas $1 \%$, a folha de pagamento em 6,1\% e o montante de empréstimo consignado em 31,9\%. No total geral no período de dezembro de 2013 a dezembro de 2014 o montante de empréstimo consignado cresceu em $16,3 \%$.

Gráfico 3.13 - Montante da folha de pagamento dos servidores docentes do mês de dezembro de 2013 e o montante do empréstimo consignado de 2013, divididos por classe. 
Empréstimo Consignado dos servidores docentes 2013

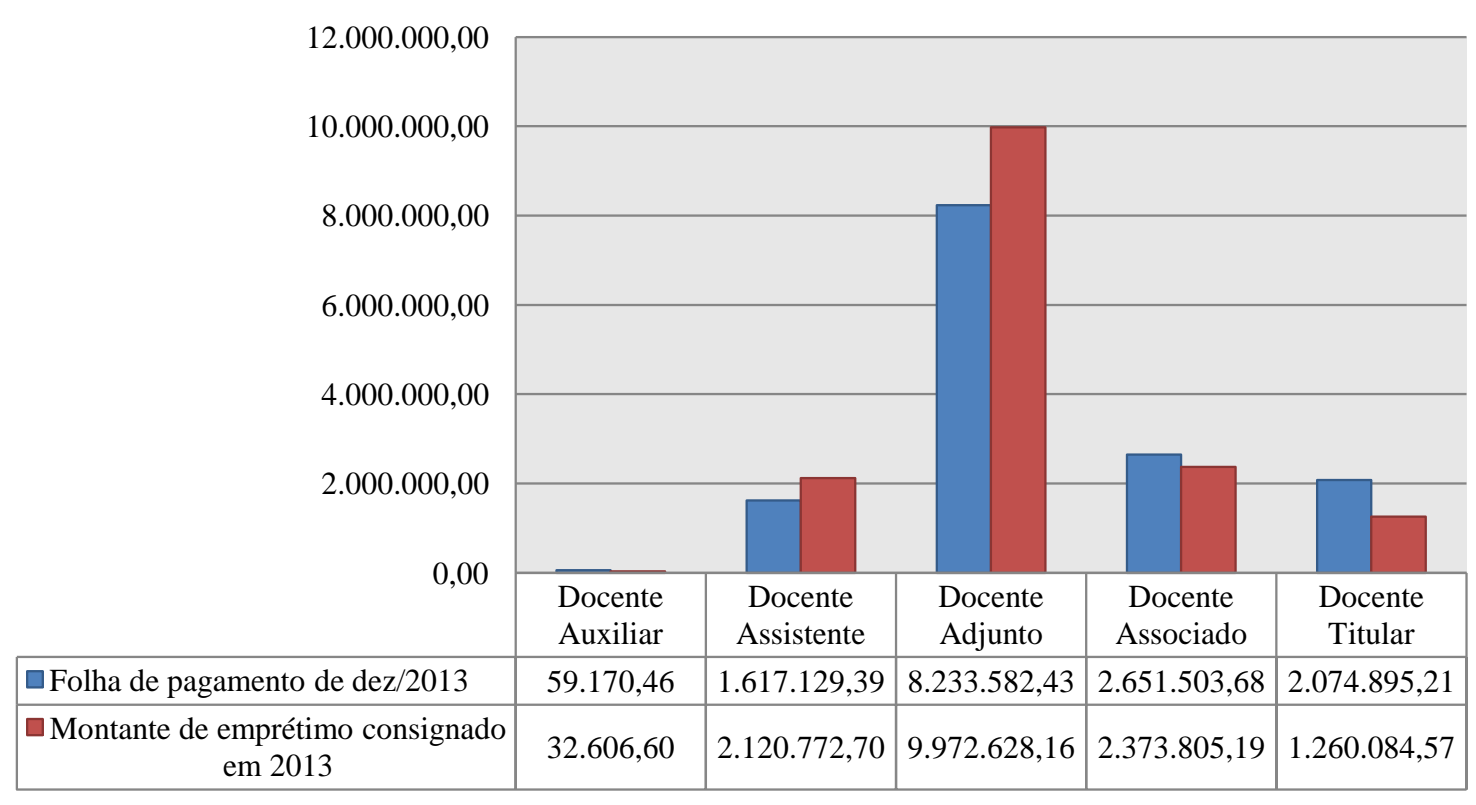

Fonte: SIAPE/DGP/CPD - Elaborado pelo pesquisador

Gráfico 3.14 - Montante da folha de pagamento dos servidores docentes do mês de dezembro de 2014 e o montante do empréstimo consignado de 2014, divididos por classe. 
Empréstimo Consignado dos servidores docentes 2014

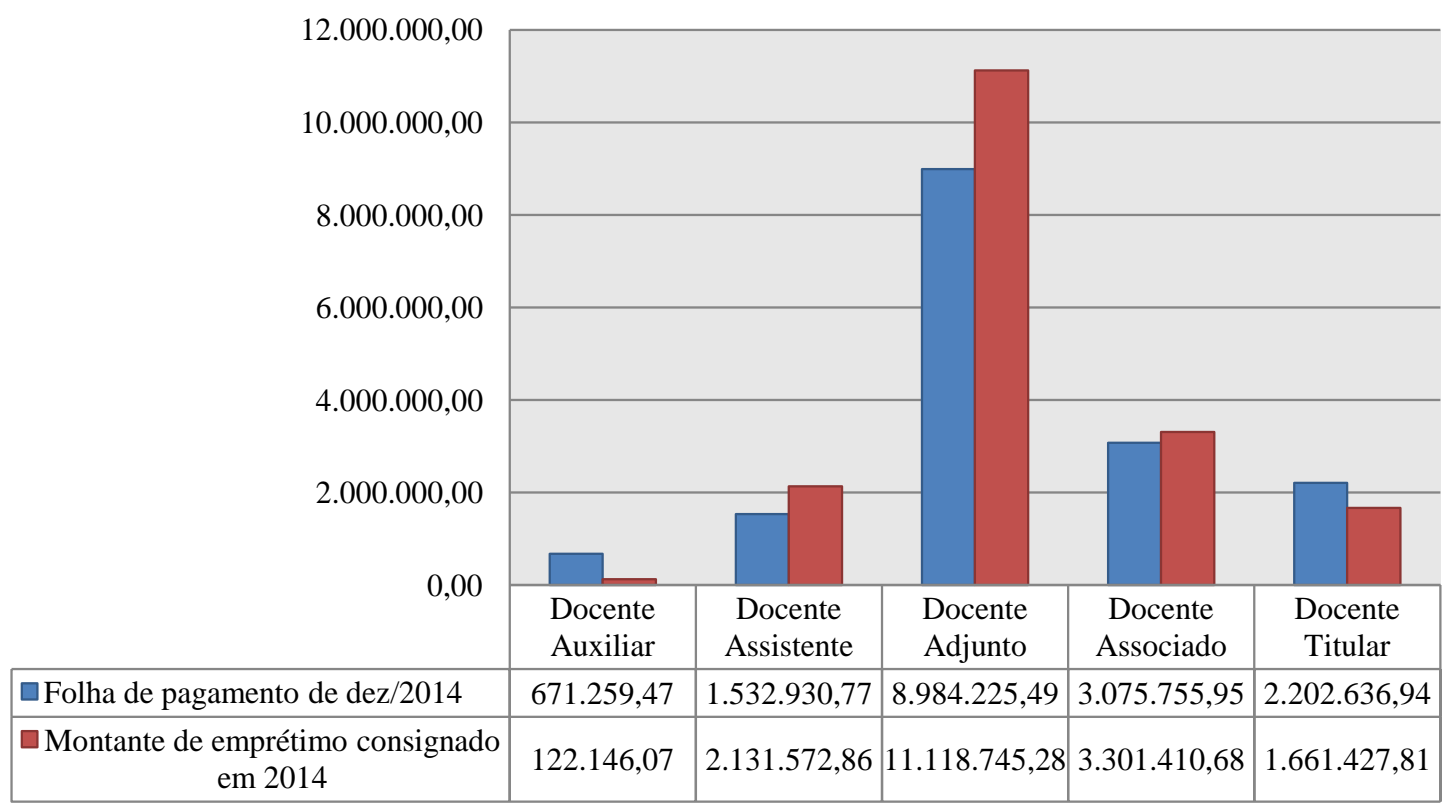

Fonte: SIAPE/DGP/CPD - Elaborado pelo pesquisador

Tabela 3.6 - Montante de empréstimo concedido aos servidores docentes (ativos e inativos) em 2013 e 2014, divididos por classe e variação \% 2013/2014.

Variação \% 2013/2014

\begin{tabular}{lrcr} 
Classe & Montante / 2013 & Montante / 2014 & \\
\hline Auxiliar & $32.606,60$ & $122.146,07$ & 74,6 \\
Assistente & $2.120 .772,70$ & $2.131 .572,86$ & 0,5 \\
Adjunto & $9.972 .628,16$ & $11.118 .745,28$ & 11,4 \\
Associado & $2.373 .805,19$ & $3.301 .410,68$ & 39,0 \\
Titular & $1.260 .084,57$ & $1.661 .427,81$ & 31,8 \\
Total & $15.759 .897,22$ & $18.335 .302,70$ & 16,3 \\
\hline
\end{tabular}

Fonte: SIAPE/DGP/CPD - elaborada pelo pesquisador.

Estamos prontos para comparar os valores das folhas de pagamento, com os montantes dos empréstimos consignados dos servidores da FUB (ativos e inativos) referentes aos anos de 2013 e 2014. Nas análises constatamos que há um crescimento ao valor monetário total dos montantes das folhas de pagamento e dos empréstimos consignado dos servidores técnicoadministrativos e dos servidores docentes (ativos e inativos) entre os anos de 2013 e 2014. 
A Tabela 3.7 mostra que em dezembro de 2013 da classe "Ensino Básico", com o total de 975 servidores técnico-administrativos, 731 estavam na folha de desconto do empréstimo consignado, totalizando o maior percentual entre as classes $(74,97 \%)$. Já da classe do "Ensino Médio", com o total de 1.318 servidores técnicos, 877 estavam na folha de desconto do empréstimo consignado, totalizando assim 66,50\%. Finalmente, a classe do "Ensino Superior" com o total de 1422 servidores técnicos 651 estavam na folha de desconto do empréstimo consignado, totalizando o menor percentual (45,78\%). Em 2013 o total de servidores eram 3.715 e desse total, 2.259 estavam na folha de desconto do empréstimo consignado, totalizando $60,80 \%$ dos servidores.

A Tabela 3.8 mostra que em dezembro de 2014 a classe "Ensino Básico" com o total de 995 servidores técnico-administrativos 702 servidores estavam na folha de desconto do empréstimo consignado, totalizando o maior percentual entre as classes (70,55\%). A classe do "Ensino Médio" com o total de 1.518 servidores técnicos 921 estavam na folha de desconto do empréstimo consignado (60,67\%). Já a classe do "Ensino Superior" com o total de 1508 servidores técnicos 666 estavam na folha de desconto do empréstimo consignado, totalizando o menor percentual (44,16\%). Em 2014 o total de servidores eram 4.041 e desse total, 2.289 estavam na folha de desconto do empréstimo consignado, totalizando 56,64\% dos servidores.

Tabela 3.7 - Quantidade de servidores técnico-administrativos da FUB em dezembro de 2013, quantidade de técnicos que possuíam empréstimo consignado com desconto em folha no ano de 2013 e o percentual em relação ao total geral, por classe.

\begin{tabular}{lccc}
\hline Classe & Quantidade técnico 12/2013 & - Quantidade Empréstimo 2013 - \% do total geral \\
\hline Ensino Básico & 975 & 731 & $74,97 \%$ \\
Ensino Médio & 1.318 & 877 & $66,50 \%$ \\
Ensino Superior & 1.422 & 651 & $45,78 \%$ \\
Total & 3.715 & 2.259 & $60,80 \%$ \\
\hline
\end{tabular}


Tabela 3.8 - Quantidade de servidores técnico-administrativos da FUB em dezembro de 2014, quantidade dos técnicos que possuíam empréstimo consignado com desconto em folha no ano de 2014 e o percentual em relação ao total geral, por classe.

\begin{tabular}{lccc}
\hline Classe & Quantidade técnico 12/2014 & - Quantidade Empréstimo 2014 - \% do total geral \\
\hline Ensino Básico & 995 & 702 & $70,55 \%$ \\
Ensino Médio & 1.518 & 921 & $60,67 \%$ \\
Ensino Superior & 1.508 & 666 & $44,16 \%$ \\
Total & 4.041 & 2.289 & $56,64 \%$ \\
\hline
\end{tabular}

Fonte: SIAPE/DGP/CPD - Elaborada pelo pesquisador.

Os Gráficos 3.15 e 3.16 mostram as quantidades de servidores técnico-administrativos que nos anos de 2013 e 2014 estavam nas folhas dos descontos referentes aos empréstimos consignados. Os gráficos mostram também as quantidades e os percentuais em relação ao total geral desses servidores divididos por classe. Os gráficos 3.15 e 3.16 que apresentam os números precisos dos servidores técnico-administrativos que solicitaram juntos às instituições financeiras o crédito consignado. Portanto, na análise realizada para os servidores técnicoadministrativos nos anos de 2013 e 2014 a busca por crédito consignado foi maior para os servidores técnico-administrativos do ensino médio (39\% e $40 \%)$ e menor para os técnicoadministrativos do ensino superior (29\% e 29\%), respectivamente.

As análises dos gráficos não confirmaram nossa expectativa assinalada em seções anteriores, uma vez não ter sido os técnico-administrativos do ensino básico os que mais procuraram pelo crédito consignado. Na verdade foi a classe intermediária que mais procurou o crédito consignado, 32\% no ano de 2013 e $31 \%$ no ano de 2014. Destaca-se que, no geral, em 2013 60,80\% dos servidores procuraram o crédito consignado, e em 2014 um pequeno decréscimo, em que $56,64 \%$ procuraram o crédito consignado. 
Gráfico 3.15 - Quantidade de servidores técnico-administrativos que em 2013 possuíam prestações a pagar de empréstimo consignado com desconto em folha de pagamento, seus percentuais por classe em relação ao total geral.

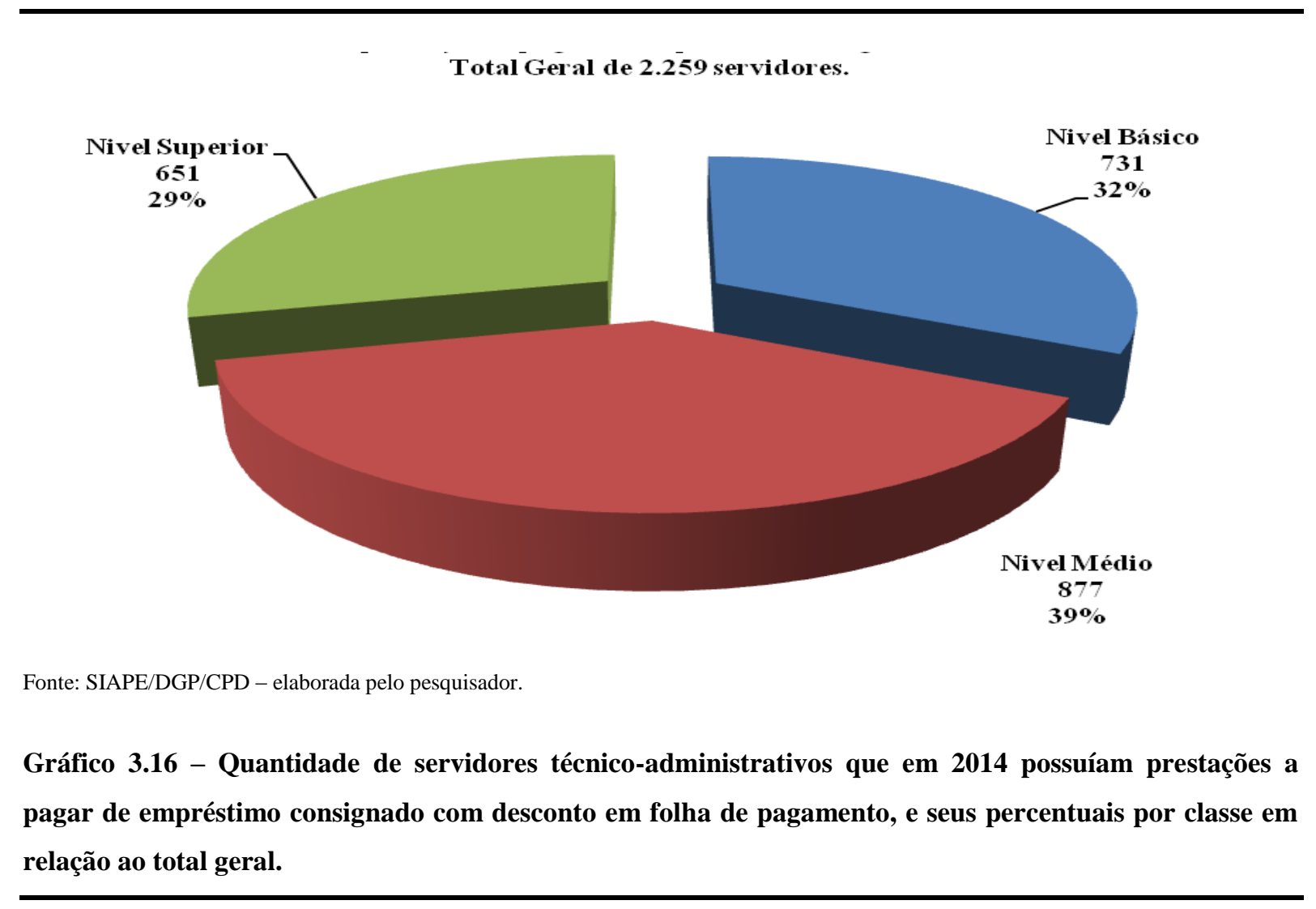

Total Geral de 2289 servidores

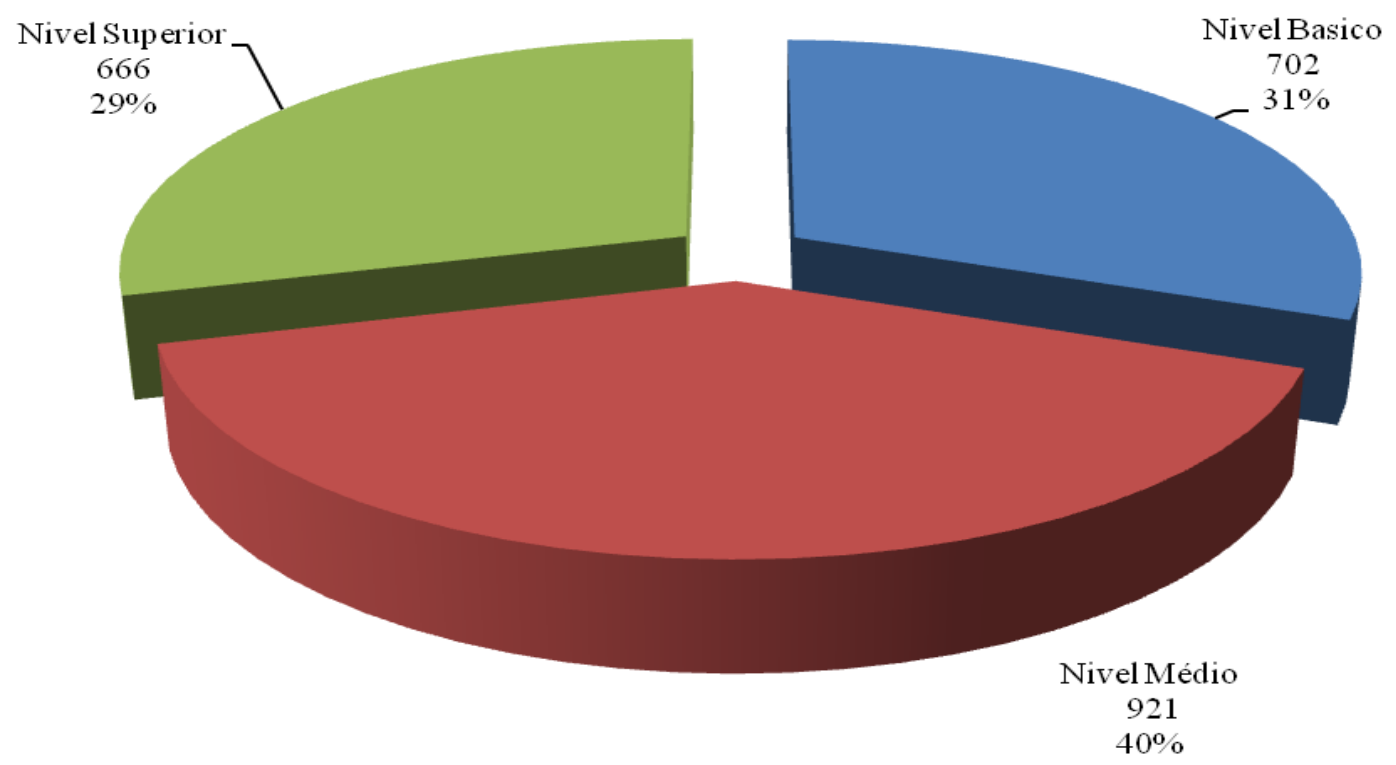


As tabelas 3.9 e 3.10 mostram que, em relação aos servidores técnico-administrativos, os servidores docentes, ativos e inativos, no geral são mais comedidos na busca por crédito consignado. A tabela 3.9 mostra que em 2013 do total de 3.138 servidores docentes, 1.007 estavam nas folhas de desconto dos empréstimos consignados. Porém, na comparação das faixas salariais por classe, não foi a classe de menor faixa salarial que mais buscou o crédito consignado, como também não foi a classe de maior faixa salarial. Destaca-se a segunda classe de maior faixa salarial, os professores associados, como a que mais buscou pelo crédito consignado com $41,03 \%$ e o menor percentual a de maior faixa salarial, os professores titulares com 12,95\%. Já em 2014 a tabela 3.9 mostra a inversão dos percentuais, sendo que, a segunda menor faixa salarial, professores assistentes, foi a que mais buscou o crédito consignado com $40,15 \%$ e a que menos buscou o crédito consignado foi exatamente a de menor faixa salarial, ou seja, os professores auxiliares com 13,93\%. Em 2014, do total de 3.200 servidores docentes, 969 estavam nas folhas de desconto dos empréstimos consignados, totalizando $30,28 \%$.

Tabela 3.9 - Quantidade de servidores docentes da FUB em dezembro de 2013, quantidade dos docentes que possuíam empréstimo consignado com desconto em folha no ano de 2013 e o percentual em relação do total geral, por classe.

\begin{tabular}{|c|c|c|c|}
\hline Classe & Quantidade docente 12/2013 & - Quantidade Empréstimo 2013 & $\%$ do total geral \\
\hline$\overline{\text { Auxiliar }}$ & 17 & 06 & $35,29 \%$ \\
\hline Assistente & 449 & 173 & $38,53 \%$ \\
\hline Adjunto & 1.961 & 591 & $30,13 \%$ \\
\hline Associado & 424 & 174 & $41,03 \%$ \\
\hline Titular & 287 & 63 & $12,95 \%$ \\
\hline Total & 3.138 & 1.007 & $32,09 \%$ \\
\hline
\end{tabular}

Fonte: SIAPE/DGP/CPD - Elaborada pelo pesquisador.

Tabela 3.10 - Quantidade de servidores docentes da FUB em dezembro de 2014, quantidade dos docentes que possuíam empréstimo consignado com desconto em folha no ano de 2014 e o percentual em relação do total geral, por classe.

\begin{tabular}{|c|c|c|c|}
\hline Classe & Quantidade docente 12/2014 & - Quantidade Empréstimo 2014 & - $\%$ do total geral \\
\hline$\overline{\text { Auxiliar }}$ & 122 & 17 & $13,93 \%$ \\
\hline Assistente & 391 & 157 & $40,15 \%$ \\
\hline Adjunto & 1.923 & 588 & $30,57 \%$ \\
\hline Associado & 474 & 146 & $30,80 \%$ \\
\hline Titular & 290 & 61 & $21,03 \%$ \\
\hline Total & 3.200 & 969 & $30,28 \%$ \\
\hline
\end{tabular}


Os Gráficos 3.17 e 3.18 mostram as quantidades de servidores docentes que nos anos de 2013 e 2014 estavam nas folhas dos descontos referentes aos empréstimos consignados. Os gráficos mostram também as quantidades e os percentuais em relação ao total geral desses servidores divididos por classe. Os Gráficos 3.17 e 3.18, divididos por classe, apresentam os números precisos dos servidores que solicitaram junto às instituições financeiras o crédito consignado. Portanto, na análise realizada para os servidores docentes nos anos de 2013 e 2014 a busca por crédito consignado foi maior para os professores adjuntos (59\% e 61\%) e menor para os professores auxiliares (1\% e $2 \%)$, respectivamente.

Análise semelhante realizada para os servidores docentes, também não confirmou nossa expectativa sobre as análises anteriores. Não foram os docentes auxiliares os que mais procuraram pelo crédito consignado e sim os docentes assistentes (17\% no ano de 2013 e $16 \%$ no ano de 2014), juntamente com os docentes associados (17\% no ano de 2013 e $15 \%$ no ano de 2014). Destaca-se que, no geral, em 2013 32,09\% dos servidores procuraram o crédito consignado, e em 2014 um pequeno decréscimo, em que 30,28\% procuraram o crédito consignado.

Gráfico 3.17 - Quantidade de servidores docentes que em 2013 possuíam prestações a pagar de empréstimo consignado com desconto em folha de pagamento, e seus percentuais em relação ao total geral.

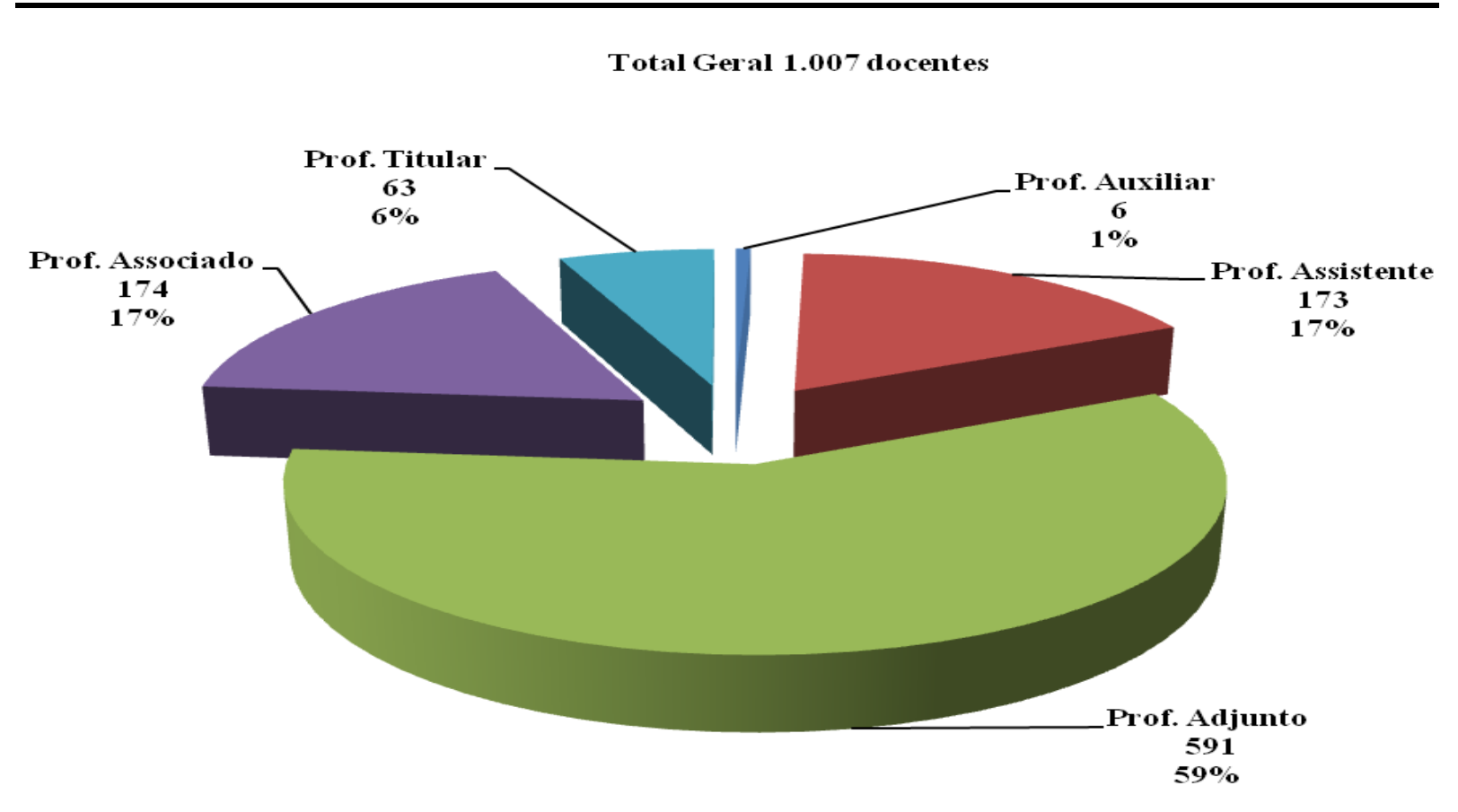


Gráfico 3.18 - Quantidade de servidores docentes que em 2014 possuíam prestações a pagar de empréstimo consignado com desconto em folha de pagamento, e seus percentuais por classe em relação ao total geral.

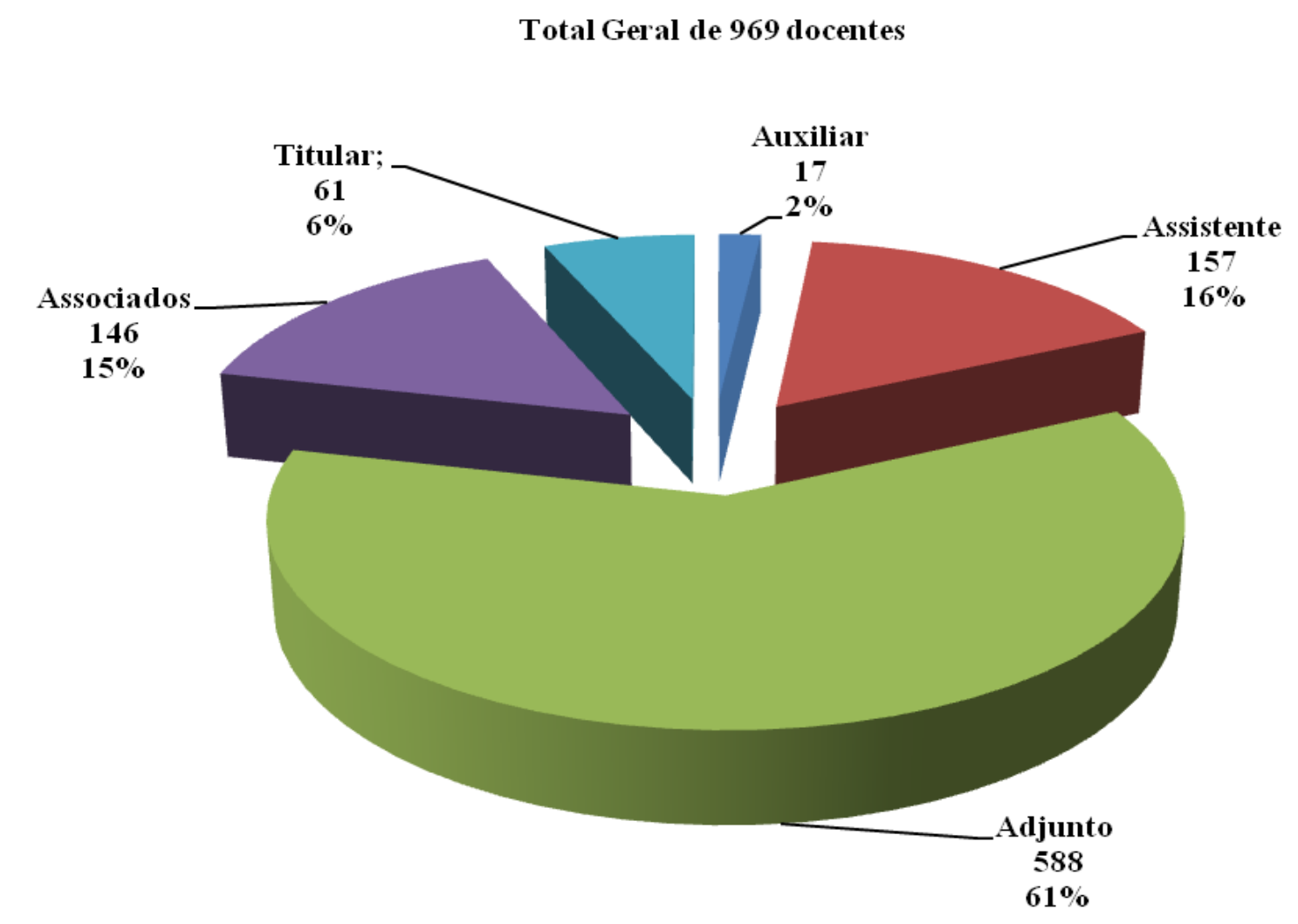

Fonte: SIAPE/DGP/CPD - elaborada pelo pesquisador.

A evolução dos montantes dos empréstimos consignados concedidos aos servidores técnico-administrativos e docentes (ativos e inativos) nos anos de 2013 e 2014 apresentadas com dados de fonte distinta da dos Gráficos e Tabelas anteriores, confirmam nossa expectativa do endividamento entre os funcionários públicos da FUB. Os gráficos 3.19, 3.20, 3.21 e 3.22 mostram as fatias do crédito recebido pelos servidores, por classe em 2013 e 2014, e as tabelas 3.11 e 3.12 comparam a evolução pelo montante do crédito recebido.

A comparação das fatias do crédito recebido entre as classes dos servidores técnicos e docentes, pela porcentagem e montante de um ano para o outro, mostra com evidencia os valores de cada parte. $\mathrm{Na}$ análise estruturamos as Tabelas 3.11 e 3.12, e enquanto há equiparação entre as classes dos servidores técnico-administrativos, principalmente entre os 
de Ensino Médio e Superior, para os servidores docentes, os professores adjuntos são detentores de mais da metade dos créditos ofertados nos anos de 2013 e 2014.

Gráfico 3.19 - Montante de empréstimo concedido em reais correntes aos servidores técnicoadministrativos no ano de 2013, divididos por classe e seus respectivos percentuais.

Total Geral de $\mathrm{R} \$ \mathbf{2 4 . 1 2 0 . 6 7 8 , 1 5}$

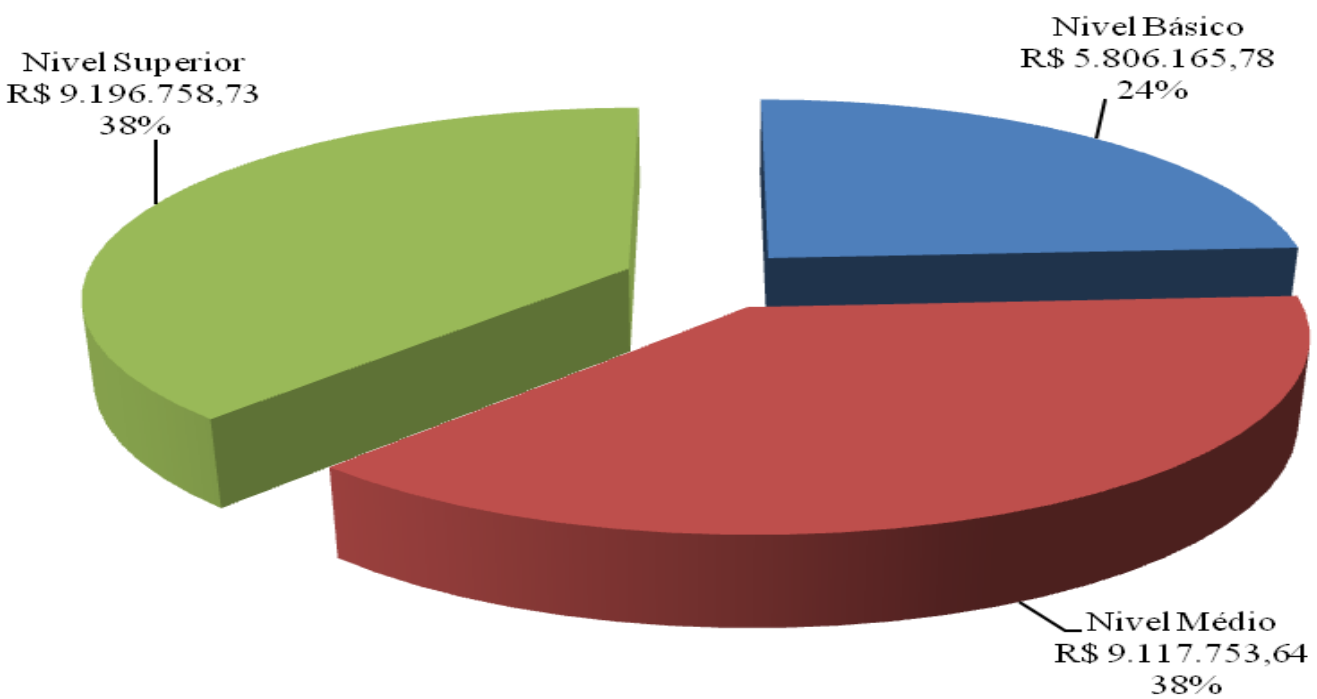

Fonte: SIAPE/DGP/CPD - elaborada pelo pesquisador.

Gráfico 3.20- Montante de empréstimos concedidos em reais correntes aos servidores técnicoadministrativos no ano de 2014, divididos por classe e seus respectivos percentuais.

Total Geral de $\mathrm{R} \$ 26.929 .788,85$

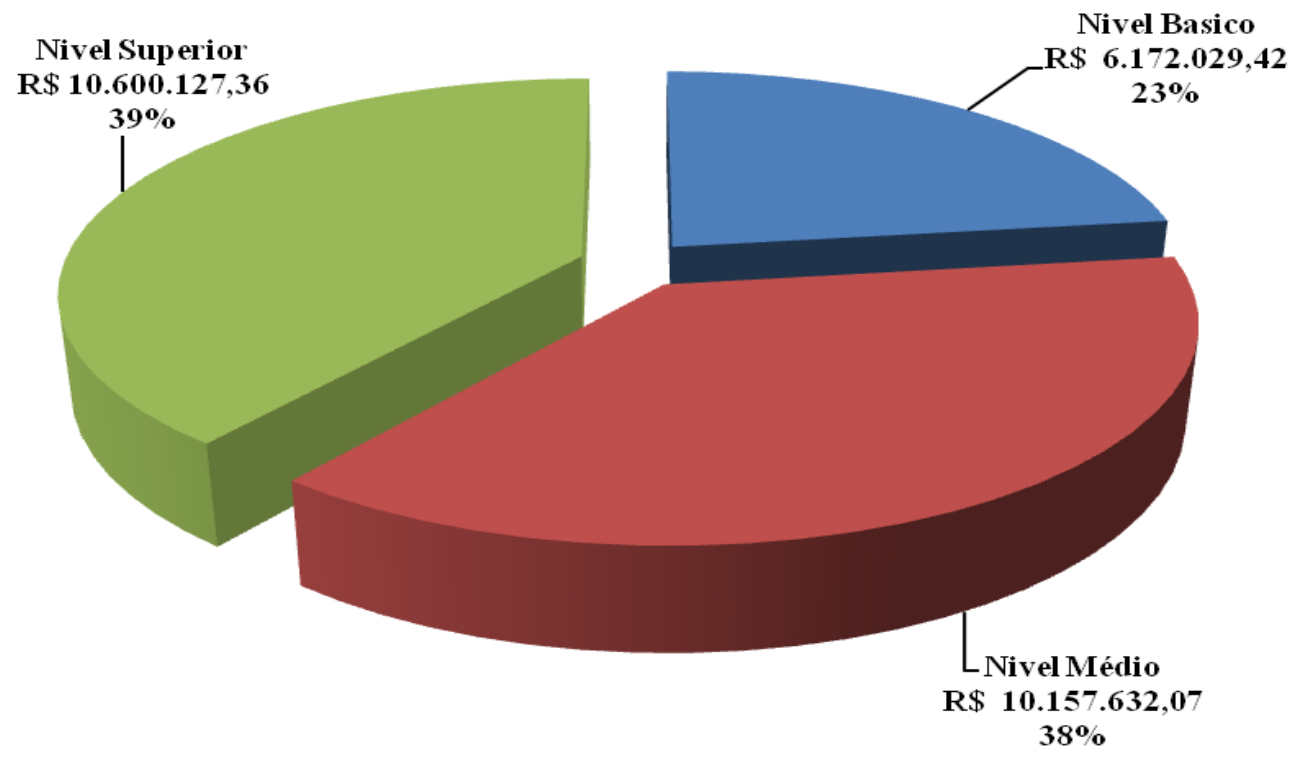

Fonte: SIAPE/DGP/CPD - elaborada pelo pesquisador. 
Tabela 3.11 - Montante de empréstimo concedido em reais correntes aos servidores técnicoadministrativos (ativos e inativos) em 2013 e 2014, e o respectivo percentual, por classe.

Variação \% 2013/2014.

\begin{tabular}{lccccc} 
Classe & Montante / 2013 & $\mathbf{\%}$ & Montante / 2014 & \% & \\
\hline Ensino Básico & $5.806 .165,78$ & 24 & $6.172 .029,42$ & 23 & 6,3 \\
Ensino Médio & $9.117 .753,64$ & 38 & $10.157 .632,07$ & 38 & 11,4 \\
Ensino Superior & $9.196 .758,73$ & 38 & $10.600 .127,36$ & 39 & 15,2 \\
Total & $24.120 .678,15$ & & $26.929 .788,85$ & & 11,6 \\
\hline
\end{tabular}

Fonte: SIAPE/DGP/CPD - elaborada pelo pesquisador.

Gráfico 3.21 - Montante de empréstimo concedido em reais correntes aos servidores docentes no ano de 2013, divididos por classe e seus respectivos percentuais.

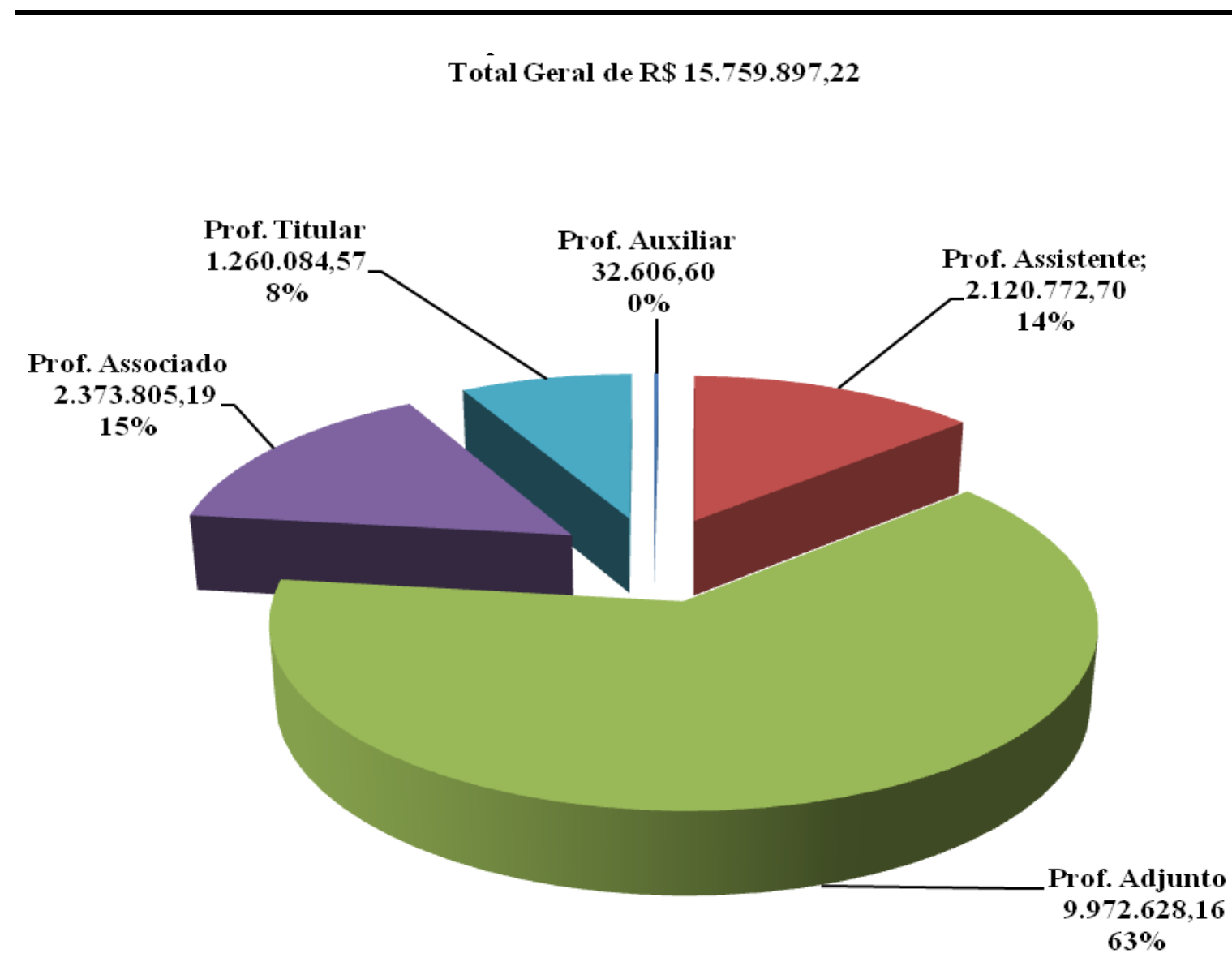

Fonte: SIAPE/DGP/CPD - elaborada pelo pesquisador. 
Gráfico 3.22 - Montante de empréstimo concedido em reais corretes aos servidores docentes no ano de 2014, divididos por classe e seus respectivos percentuais.

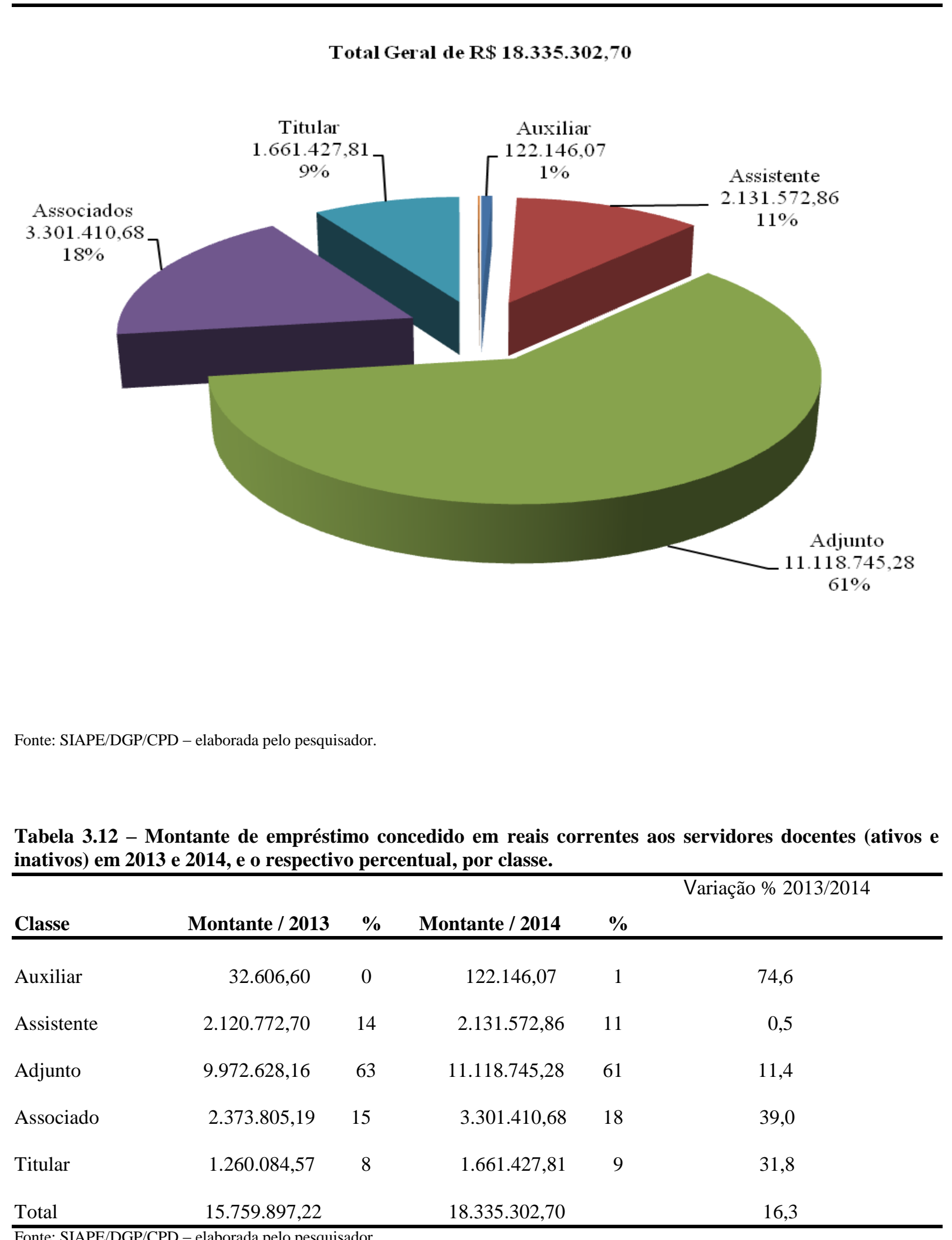

Fonte: SIAPE/DGP/CPD - elaborada pelo pesquisador. 


\subsection{Resumo dos principais resultados.}

A análise que acabamos de concluir apresentou alguns resultados que devem ser contrapostos a aspectos que são enfatizados na literatura especializada - apresentada no Capitulo 1 - e nos dados sobre endividamento de pessoas físicas no Brasil - resumidos no Capítulo 2. Nesta seção final é relevante destacar que:

Os anos 2013 e 2014 testemunharam crescimento no número e no valor da folha de pagamento dos servidores públicos da FUB/UnB. As Tabelas 3.13 e 3.14 resumem essas informações para que fique claro que analisamos um período de crescimento do valor monetário da folha de pagamentos e do número de funcionários públicos da FUB; não foi um período de recessão econômica, com redução do salário nominal ou real.

Enquanto mais da metade dos servidores técnicos solicitaram empréstimos consignados nos anos de 2013 e 2014, menos de um terço da população dos docentes solicitaram nos anos de 2013 e 2014, empréstimos consignados. A Tabela 3.15 resumem essas informações com uma clara correlação negativa com o nível de escolaridade (quanto maior esta, menor a demanda).

Apesar dessa estabilidade econômica, a demanda por crédito (em termos de empréstimo consignado) não se altera ao longo do período; muito pelo contrário, o montante demandado de empréstimo consignado cresce entre $11,6 \%$ (técnico-administrativos) e 16,3\% (professores), como mostra a Tabela 3.16.

Tabela 3.13 - Numero de Funcionários Públicos - FUB

Técnico-administrativo

\begin{tabular}{|c|c|c|c|c|c|}
\hline Classe & Jan/13 & dez/13 & jan/14 & dez/14 & Variação \% jan/13 a dez/14 \\
\hline Ensino Básico & 986 & 975 & 1.004 & 995 & 0,9 \\
\hline Ensino Médio & 1.335 & 1.318 & 1.316 & 1.538 & 15,2 \\
\hline Ensino Superior & 1.419 & 1.422 & 1.420 & 1.508 & 6,2 \\
\hline Total & 3.740 & 3.715 & 3.740 & 4.041 & 8,0 \\
\hline
\end{tabular}

\section{Docente}

\begin{tabular}{|c|c|c|c|c|c|}
\hline Classe & $\mathrm{Jan} / 13$ & $\mathrm{dez} / 13$ & $\mathrm{jan} / 14$ & $\mathrm{dez} / 14$ & Variação \% jan/13 a dez/14 \\
\hline Auxiliar & 13 & 17 & 17 & 122 & 38,4 \\
\hline Assistente & 470 & 449 & 445 & 391 & $-8,3$ \\
\hline Adjunto & 1.956 & 1.961 & 1.960 & 1.923 & $-9,8$ \\
\hline Associado & 281 & 424 & 428 & 474 & 68,6 \\
\hline Titular & 287 & 287 & 287 & 290 & 1,0 \\
\hline Total & 3.007 & 3.138 & 3.137 & 3.200 & 6,4 \\
\hline
\end{tabular}


Tabela 3.14 - Valor da Folha de Pagamento - FUB

Técnico-administrativo

\begin{tabular}{|c|c|c|c|}
\hline Classe & Dezembro / 2013 & Dezembro / 2014 & Variação \% 2013/2014 \\
\hline Ensino Básico & $2.158 .596,84$ & $2.359 .353,91$ & 9,3 \\
\hline Ensino Médio & $3.784 .760,05$ & $4.632 .203,87$ & 22,4 \\
\hline Ensino Superior & $6.374 .760,05$ & $4.632 .203,87$ & 15,5 \\
\hline Total & $12.318 .194,99$ & $14.357 .245,06$ & 16,6 \\
\hline
\end{tabular}

\section{Docente}

\begin{tabular}{|c|c|c|c|}
\hline Classe & Dezembro / 2013 & Dezembro / 2014 & Variação \% 2013/2014 \\
\hline Auxiliar & $59.170,46$ & $671.259,47$ & 34,4 \\
\hline Assistente & $1.617 .129,39$ & $1.532 .930,77$ & $-5,5$ \\
\hline Adjunto & $8.233 .582,43$ & $8.984 .225,49$ & 9,1 \\
\hline Associado & $2.651 .503,68$ & $3.075 .755,95$ & 16,0 \\
\hline Titular & $2.074 .895,21$ & $2.202 .636,94$ & 6,1 \\
\hline Total & $14.636 .281,17$ & $16.466 .808,62$ & 12,5 \\
\hline
\end{tabular}

Tabela 3.15 - Número de Funcionário / Número de Empréstimo 2013/2014

Técnico-administrativo

\begin{tabular}{|c|c|c|c|c|c|c|}
\hline Classe & dez/13 & 2013 & $\%$ & dez/14 & 2014 & $\%$ \\
\hline Ensino Básico & 975 & 731 & 74,97 & 995 & 702 & 70,55 \\
\hline Ensino Médio & 1.318 & 877 & 66,50 & 1.518 & 921 & 60,67 \\
\hline Ensino Superior & 1.422 & 651 & 45,78 & 1.508 & 666 & 44,16 \\
\hline Total & 3.715 & 2.259 & 60,80 & 4.041 & 2.289 & 56,64 \\
\hline
\end{tabular}

\section{Docente}

\begin{tabular}{|c|c|c|c|c|c|c|}
\hline Classe & dez/13 & 2013 & $\%$ & dez/14 & 2014 & $\%$ \\
\hline Auxiliar & 17 & 06 & 35,29 & 122 & 17 & 13,93 \\
\hline Assistente & 449 & 173 & 38,53 & 391 & 157 & 40,15 \\
\hline Adjunto & 1.961 & 591 & 30,13 & 1.923 & 588 & 30,57 \\
\hline Associado & 424 & 174 & 41,03 & 474 & 146 & 30,80 \\
\hline Titular & 287 & 63 & 12,95 & 290 & 61 & 21,03 \\
\hline Total & 3.138 & 1.007 & 32,09 & 3.200 & 969 & 30,28 \\
\hline
\end{tabular}


Tabela 3.16 - Montante Empréstimo Consignado 2013/2014

Técnico-Administrativo

\begin{tabular}{|c|c|c|c|}
\hline Classe & 2013 & 2014 & Variação \% 2013/2014 \\
\hline Ensino Básico & $5.806 .165,78$ & $6.172 .029,42$ & 6,3 \\
\hline Ensino Médio & $9.117 .753,64$ & $10.157 .632,07$ & 11,4 \\
\hline Ensino Superior & $9.196 .758,73$ & $10.600 .127,36$ & 15,2 \\
\hline Total & $24.120 .678,15$ & $26.929 .788,85$ & 11,6 \\
\hline
\end{tabular}

\section{Docente}

\begin{tabular}{|c|c|c|c|}
\hline Classe & 2013 & 2014 & Variação \% 2013/2014 \\
\hline Auxiliar & $32.606,60$ & $122.146,07$ & 74,6 \\
\hline Assistente & $2.120 .772,70$ & $2.131 .572,86$ & 0,5 \\
\hline Adjunto & $9.972 .628,16$ & $11.118 .745,28$ & 11,4 \\
\hline Associado & $2.373 .805,19$ & $1.66 .427,81$ & 31,8 \\
\hline Titular & $1.260 .084,57$ & $1.661 .427,81$ & 31,8 \\
\hline Total & $15.759 .897,22$ & $18.335 .302,70$ & 16,3 \\
\hline
\end{tabular}




\section{CONCLUSÃO}

O objetivo desta dissertação foi analisar o nível de endividamento do servidor público federal brasileiro após uma década de implementação do empréstimo consignado com desconto em folha de pagamento. Para que nossa empreitada pudesse ser factível, analisamos uma amostra dos servidores públicos federais: estudamos o caso específico do endividamento do servidor público federal da Fundação Universidade de Brasília (FUB). Nossos resultados demonstraram que esse endividamento tem crescido com a ampliação da oferta de crédito e pela facilidade de obtê-lo, ampliando o poder de compra desse servidor no presente, mas reduzindo-o no futuro dado o custo de cumprir com as suas obrigações de pagamento de sua dívida.

Os relatórios dos empréstimos concedidos aos servidores docentes e técnicoadministrativos da Fundação Universidade de Brasília (FUB) indicaram que, devido à facilidade de crédito com prazos máximos para quitação de até 72 meses, são muitos os servidores que possuem empréstimos consignados com desconto em folha de pagamento. Mesmo tendo no quadro de servidores da FUB muitos que não realizam empréstimos bancários, a pesquisa mostrou que em 2013 e 2014 mais da metade dos servidores técnicoadministrativos solicitaram empréstimos consignados. Para os servidores docentes, a pesquisa mostrou que em 2013 e 2014, os professores foram mais comedidos, pois um pouco menos um terço da população solicitou empréstimos consignados.

A análise da relação entre a quantidade de empréstimos tomados e o total dos servidores técnico-administrativos mostrou que, nos anos de 2013 e 2014 foram concedidos para mais da metade dos servidores, montantes crescentes a todas as classes funcionais. Porém, o crescimento desse montante foi mais do que proporcional ao aumento do número total de servidores no mesmo período. A classe dos servidores do Ensino Básico apresentou um elevado percentual de tomadores de empréstimos em relação ao total de servidores nessa classe. As demais classes apresentaram percentuais decrescentes, porém ainda bastante elevados. O Ensino Superior apresenta o menor percentual. Todavia o montante em reais não é proporcional à quantidade de empréstimos concedidos, uma vez que quanto maior o vencimento básico maior o montante em reais corrente de empréstimos, porém, menor a quantidade de solicitações de empréstimos.

Fica evidente, então, a significativa demanda por crédito consignado entre técnicoadministrativos da FUB. Percebe-se, também, uma clara correlação negativa de empréstimos com o nível de escolaridade (quanto maior esta, menor a demanda) e com o nível de renda (quanto maior esta, menor a demanda). Assim podemos destacar que escolaridade e renda são 
variáveis relevantes para uma análise econômica do endividado do setor público brasileiro e, provavelmente, do brasileiro em geral.

A análise da relação entre a quantidade de empréstimos tomados e o número total de servidores docentes mostrou que em 2013 e 2014 foram concedidos para um pouco menos de um terço da população, montantes crescentes a todas as classes. A pesquisa mostrou que as classes Auxiliar e Titular, de menor e maior vencimento básico, foram as que menos solicitaram empréstimos, tanto na quantidade como no montante em relação ao número total de professores em cada uma dessas duas classes. A classe de Adjunto foi a que mais solicitou empréstimos. As outras duas intermediárias, Assistente e Associado, solicitaram empréstimos na mesma proporção da participação do número de seus professores no total da UnB.

Apesar do expressivo crescimento do crédito/PIB nos últimos anos, a julgar pela comparação internacional, o Brasil ainda figura entre os países com menor relação crédito/PIB do mundo. Estudos apontam que em economias desenvolvidas o endividamento da população tende a ultrapassar $100 \%$ da renda anual. Contudo, mesmo que a expansão do crédito à pessoa física esteja ocorrendo no Brasil, paralelamente está ocorrendo um acelerado processo de endividamento das famílias. E ambos aconteceram em um momento de crescimento econômico, com incremento do emprego e da renda da população. A destacar que nosso estudo mostrou um crescimento real (acima da inflação) no valor monetário médio das remunerações dos servidores técnico-administrativos e docentes (ativos e inativos) da FUB entre os dois períodos pesquisados (2013/2014). A folha salarial cresceu mais do que o número de servidores em cada classe, paralelamente, os relatórios dos empréstimos consignados mostraram crescimento do montante.

A dúvida que imediatamente surge - e que deve ser estímulo para pesquisas futuras é o que acontecerá com o endividamento em uma conjuntura de baixo crescimento econômico, do emprego e da renda?. Com o aumento da taxa de juros - e já temos uma das maiores taxas de juros do mundo - temos um freio ao crédito, mas temos também um acelerador do peso do serviço da dívida no salário. Chegamos ao limite do endividamento "saudável" da população? Existe um consenso de que o patamar "máximo saudável" de comprometimento com empréstimos e financiamentos é de $30 \%$ da renda disponível; será que esse patamar será respeito por uma população em uma economia de baixo crescimento?

Podemos, então, manifestar nossa expectativa como consequência das políticas públicas de crédito à pessoa física no Brasil, especificamente o crédito consignado, por ser uma modalidade de empréstimo pessoal mais seguro para quem está emprestando, como para quem está tomando, com taxas de juros mais baixas que as praticadas nas demais modalidades 
de empréstimo pessoal. No entanto, a facilidade de acesso ao crédito associado à incapacidade de administrar dinheiro são males que podem causar o endividamento pessoal e familiar. Se pararmos para pensar, estamos sujeitos a um mundo financeiro muito mais complexo que o das gerações anteriores.

No entanto, o nível de educação financeira da população não acompanhou esse aumento de complexidade (BC). As pessoas contraem dívidas significativas em relação aos seus ganhos financeiras às vezes ocasionadas por acidentes pessoais e problemas de saúde, entre outros. Segundo Artifon e Piva (2013) o descontrole financeiro e o endividamento não dependem diretamente da renda mensal do indivíduo, mas refletem os apelos exacerbados da sociedade de consumo, de modo a denotar que este comportamento financeiro não pode ser explicado por um viés de racionalidade, pois nele interferem aspectos psicológicos e culturais.

Infelizmente, não faz parte do cotidiano da maioria das pessoas buscar informações que as auxiliem na gestão de suas finanças. Para agravar essa situação, não há uma cultura coletiva, ou seja, uma preocupação da sociedade em torno do tema. Nas escolas e até nas Universidades, pouco ou nada é falado sobre o assunto. Nas empresas, não compreendendo a importância de ter seus funcionários alfabetizado financeiramente, também não investem nessa área. Igualmente entre os amigos, assuntos ligados à gestão financeira pessoal muitas vezes são considerados invasão de privacidade e pouco se conversa em torno do tema.

Enfim, assim como o psicólogo trabalha para promover a saúde psíquica do individuo, o economista profissional poderá ter também como uma das funções o trabalho de promover a saúde financeira dos profissionais de uma empresa. É neste sentido que um dos objetivos desse trabalho é assinalar a possibilidade de existir um profissional da área de finanças, economia ou correlatas no Decanato de Gestão de Pessoas - DGP da Fundação Universidade de Brasília - FUB para prestar serviços fundamentais à saúde financeira dos servidores da FUB, através de um programa de educação financeira, com objetivos de sanar os sérios problemas como depressão, ansiedade, abalos na autoestima, relação familiar e principalmente relação no ambiente de trabalho. A proposta não é a solução para os problemas do endividamento dos servidores da FUB, é apenas uma pequena contribuição para que no futuro outras contribuições apareçam para minimizar os problemas financeiros desses profissionais. 


\section{REFERÊNCIAS BIBLIOGRÁFICAS}

ACCIOLY, Isalva. A Prática de Educação Financeira. Disponível em: <http;//www.conpet.gov.br/artigo.php?segmento=\&id10.> Acesso em 20 nov. 2014.

ALMEIDA, Notlin de Araujo. Endividamento e sobre endividamento do servidor público do Poder Executivo do estado do Ceará. Dissertação Mestrado Profissional em Economia do Setor Público. Universidade do Ceará, Fortaleza, 2012.

ARTIFON, Simone; PIVA, Maristela. Endividamento nos dias atuais: Fatores Psicológicos Implicados neste Processo. (2013). \{Artigo Científico\}. Disponível em: http://www.psicologia.pt/artigos/textos/A0771.pdf. Acesso em: 07 abr. 2015.

ATKINSON, Anthony A.; BANKER, Rajiv D.; YOUNG, S. Mark. Contabilidade gerencial. São Paulo. Atlas, 2000.

BERTOLA, Giuseppe; HOCHGUERTE, Stefan. Household Debt and Credit. (Università di Torino; VU University Amisterdam) This draft: May 2005.

BRASIL, Banco Central do. É possível sair do superendividamento. Departamento de Educação Financeira. Disponível em: <http://www.bcb.gov.br/pre/pef/port/folder_serie_II_\%E9_possivel_sair_do_superendividam ento.pdf.> Acesso em: 20 mai. 2014.

Evolução regional do crédito consignado, boletim regional do

Banco Central do Brasil, 2011. Disponível em:
<http://www.bcb.gov.br/pec/boletimregional/port/2011/04/br201104b2p.pdf>. Acesso em: 22 abr. 2014.

. Política creditícia, monetária e fiscal: relatório de inflação, 2005. Disponível em: <http://www.bcb.br/htms/relinf/port/2005/06/ri200506c3p.pdf>. Acesso em: 22 abr. 2014.

$\overline{18 / 07 / 2012 \quad \mathrm{a}} \cdot \begin{array}{lll}\text { 24/07/2012. } & \text { Disponível }\end{array}$
<http://www.bcb.gov.br/fis/taxas/htms/tx012010.asp>. Acesso em: 22 abr. 2014.

Relações com investidores. Disponível em: <http://www.bb.com.br/portalbb/page51,136,3442,0,0,1,8.bb?codigonoticia=4816\&codigoMe $\mathrm{nu}=0>$. Acesso em: 22 abr. 2014.

BARONE, Francisco Marcelo; SADER, Emir. Acesso ao crédito na Brasil: evolução e perspectivas. Revista da Administração Pública. 2008, vol.42, n. ํ 6, p. 1.249-1.267.

CALIL, Mauro. Do Portal: Servidor Público Federal - 20/11/2013. Disponível em: httpw://PT-

<br.facebook.com/permalink.php?story_fbid=441009719332102\&id=254090891357320\&sub story_index=0.> acesso em: 29 nov. 2014. 
CERBASI, Gustavo. O que é planejamento financeiro? Disponível em: $<\mathrm{http}$ ://www.maisdinheiro.com.br/artigos/o-que-e-planejamento-financeiro.html>. Acesso em 25 abr. 2014.

CERVO, Amando Luiz; BERVIAN, Pedro Alcino. Metodologia científica. 5. ed. São Paulo: Makron Books, 2002.

CLAUDINO, L. P.; NUNES, M. B.; DA SILVA, F.C. Finanças pessoais: um estudo de caso com servidores públicos. Universidade Federal de Viçosa, 2009, Viçosa

COSTA, E. A.; MANOLESCU, F. M. K. A Importância do Crédito na Economia Universidade do Vale do Paraíba, 2003, São José dos Campos - SP.

DOLVIN, S. D.; TEMPLETON, W. K. Financial education and asset allocation. Financial Services Revigw, v. 15, n. 3, p. 133, Summer 2006.

DOURADO JUNIOR, Dorival. Mercados: endividamento e inadimplência - mitos e verdades. Bela Vista, 2012.

DUPAS, Gilberto. Espaços para o crescimento sustentado da economia brasileira. São Paulo: Unesp, 2007. p. 144.

ELABORAÇÃO DE PROJETOS GOVERNAMENTAIS DE CAPTAÇÃO DE RECURSOS

- Instruções Básicas. Disponível em: <http://www.sgc.goias.gov.br/upload/arquivo/201206/elaboracao-de-projeto-governamentais-de-captacao-de-recursos_instrucoes-basicas_v11.

EID JÚNIOR, Willian; GARCIA, Fábio Gallo. Como fazer o orçamento familiar. 3. ed. São Paulo: Publifolha, 2001.

FECOMERCIO-SP. Radiografia do Endividamento das Famílias nas Capitais Brasileira. Disponível em http://www.fecomercio.com.br/noticiaArtigo/Artigo/5185. Acesso em 22.nov.2014.

FREITAS, Vladimir Passos. Endividamento e seus reflexos em profissionais do Direito. Artigo. Disponível em: http://www,conjur.com.br/2012-jul-29/segunda-leituraendividamento-relexos-profissionais-direito. Acesso em: 29 nov. 2014.

FOX, L.; HOFFMANN, J.; WELCH, C. Federal reserve personal financial education initiatives. Federal Reserve Bulletin, Autumn, 2004. Disponível em: $<$ http://www.federalreserve.gov/pubs/bulletin/2004/autumn04_fined.pdf $>$. Acesso em: 17 mar 2015.

FRANKENBERG, Louis. Seu futuro financeiro: você é o maior responsável. 16. ed. Rio de Janeiro: Campus, 1999.

GALEANO, Edileuza Vital; FEIJÓ, Carmem. Crédito e Crescimento Econômico: Evidências a partir de um Painel de Dados Regionais para a Economia Brasileira nos anos 2000. Documentos Técnico-Científicos. Recebido para publicação em 25.01.2011

Gil, Antonio Carlos. Como elaborar projetos de pesquisa. 4. ed. São Paulo: Atlas, 2002. 
GRÜSSNER,Paula M. Administrando as finanças pessoais para a criação de patrimônio. Porto Alegre, 2007. Trabalho de Conclusão de Curso - Universidade Federal do do Rio Grande do Sul, Curso de Administração.

LCA Consultores. Endividamento do brasileiro é recorde. Disponível em http://www.sindicomitabuna.com.br/noticias/28-noticias.html?start=184? Acesso em 23.nov.2014.

LEITÃO, Miriam. A saga brasileira: a longa luta de um povo por sua moeda. Rio de Janeiro: Record, 2011.

LOTURCO, Roseli. Dinheiro. Revista Você S. A. Disponível em: http://www,conjur.com.br/2012-jul-29/segunda-leitura-endividamento-relexos-profissionaisdireito. Acesso em: 29 nov. 2014.

LOUREIRO, Ricardo. O fantasma do crescimento endividamento do consumidor. press.experian.com, experian2014.all.rights reserved. São Paulo, 2014.

MACIEL, Tulio. Servidores Públicos já devem R\$ 135,2 bilhões aos bancos por empréstimos. Artigo. Disponível em: <http;//WWW.correiobrasiliense.com.br/app/noticia/economia/213/11/29/interna_economia,4 00828/servidores-publicos-já-devem-r-135-2-bilhoes-aos-ancos-por-emprestimo.sht.> Acesso em 28 nov. 2014.

MAIA, Carlos Donizeti Macedo. A democratização do crédito no Brasil: o crédito consignado - textos para discussão 22/2005. São Paulo: PUCSP, 2005.

MANSON, C. L. J.; WILSON, R. M. S. Conceptualizing financial literacy. Businesse School Research Series Paper, 2007.

MARCONI, Marina de Andrade, LAKATOS, Eva Maria. Fundamentos de metodologia científica. 6. ed. São Paulo: Atlas, 2005.

MARQUES, M. L. M.; FRADE, C. Regular o sobre endividamento. Coimbra, 2003. Faculdade de Economia, Universidade de Coimbra, 2003.

MOREIRA, Bruno Reinaldo. Direito Administrativo. Belo Horizonte: Del Rey, 2005, p. 191.

OCDE (Organização de Cooperação e de Desenvolvimento Econômico). OECD's Financial Education Project.Assessoria de Comunicação Social, 2004. Disponível em: <www.oecd.org/ >. Acesso em: 22 nov. 2014.

OCDE/OECD - Organisation for Economic and Co-Operation Development. Improving Financial Literacy. Analysis of Issues and Policies. Paris, 2005.

Pesquisa de Orçamentos Familiares - POF 2008-2009. Despesas Rendimento e Condições de Vida. 
Pesquisa Nacional de Endividamento e Inadimplência do Consumidor -PEIC - CNC/2012 Divisão Econômica - Rio de Janeiro. Disponível em: <http://www.cnc.org.br/sites/defaut/files/arquivos/peic_janeiro_2012.PDF>. Acesso em 22 nov. 2014

Portal eletrônico do Superior Tribunal de Justiça. Superendividamento: uma realidade para mais de $9 \%$ dos brasileiros. Disponível em: <http://www.stj.jus.br/portal_stj/publicacao/engine.wsp?tmp.area=448\&tmp.texto=\%2010405 5>. Acesso em: 20 mai. 2014.

HANSON, Marianne. Principais dívidas das famílias são com cartão de crédito. Artigo. Disponível em: http://www.agenciabrasil.ebc.com.br/economia/noticia/2014-09/percentualde-familias-endividadas-cai-entre-agosto-e-setembro.> Acesso em: 24 nov.2014.

Recommendation on principles and good practices for financial education and Awareness. Jul. 2005. Disponível em: < http://www.oecd.org/ > Acesso em: 18 mar 2015.

RIBEIRO, Lair. Prosperidade. São Paulo: Moderna. 1999.

ROCHA, Sonia. Instituto de Estudos do Trabalho e Sociedade - IETS, 2010. Disponível em http://www.gazetadopovo.com.br/economia/68-das-familias-brasileiras-gastam-mais-de-queganham-1!44kfiorvysfahuzde3p1npq.> Acesso em 22.nov.2014.

SAVOIA, J. R. F.; SAITO, A. T.; SANTANA, F. DE A.; Paradigmas da educação financeira no Brasil. Rio de Janeiro: Revista de Administração Pública, v. 46, p. 41- 1121, Nov./Dez., 2007.

SLYWOTZKY, Adrian. A arte da rentabilidade. HSM Management, 34, setembro-outubro 2002, pg.19/26, artigo.

SOUZA, A. F.; TORRALVO, C. F. A Gestão dos Próprios Recursos e a Importância do Planejamento Financeiro Pessoal. [on line] Disponível em: . Acesso em 22 jun.2014.

SOUZA, M. A. P. O uso do crédito pelo consumidor: percepções multifacetadas de um fenômeno intertemporal. 2013. 118 f. Dissertação (Mestrado em Psicologia Social do Trabalho e das Organizações) - Universidade de Brasília, Brasília, 2013.

TAKEDA, Tony; DAWID, Paulo Evandro. Um Estudo sobre Comportamento de Tomadores e Ofertantes no Mercado de Crédito. Artigo, trabalhos para discussão. Banco Central do Brasil - BCB. Dezembro, 2013

TEIXEIRA, Gustavo Cesar Terra. Uma solução para o superendividamento. Disponível

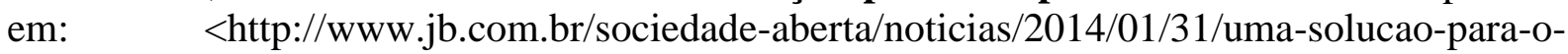
superendividamento>. Acesso em: 26 abr. 2014.

WORTHINGTON, A. C. Predicting financial literacy in Australia. Financial Services Review, v. 15, n. 1, p. 59-79, Spring 2006.

YIN, Robert K. Estudo de caso: planejamento e métodos. 3. ed. Porto Alegre: Bookman, 2005. 


\section{ANEXOS}

Tabela A.1 - Vencimento básico, piso e teto por classe e nível de formação acadêmica - 2104 em R\$.

\begin{tabular}{|c|c|c|}
\hline \multicolumn{3}{|c|}{ Docente regime de trabalho: 20 horas } \\
\hline Classe/Nível & Vencimento/Piso & Vencimento/Teto \\
\hline Auxiliar/Graduação & $1.966,67$ & $1.999,75$ \\
\hline Auxiliar/Aperfeiçoamento & $2.036,49$ & $2.072,34$ \\
\hline Auxiliar/Especialização & $2.119,02$ & $2.161,10$ \\
\hline Auxiliar/Mestrado & $2.394,74$ & $2.443,03$ \\
\hline Auxiliar/Doutorado & $2.752,60$ & $2.802,35$ \\
\hline Assistente/Graduação & $2.069,79$ & $2.093,40$ \\
\hline Assistente/Aperfeiçoamento & $2.143,37$ & $2.167,83$ \\
\hline Assistente/Especialização & $2.243,33$ & $2.277,16$ \\
\hline Assistente/Mestrado & $2.527,53$ & $2.580,95$ \\
\hline Assistente/Doutorado & $2.893,33$ & $2.971,22$ \\
\hline Adjunto/Graduação & $2.193,83$ & $2.357,53$ \\
\hline Adjunto/Aperfeiçoamento & $2.276,12$ & $2.544,58$ \\
\hline Adjunto/Especialização & $2.391,31$ & $2.587,38$ \\
\hline Adjunto/Mestrado & $2.691,15$ & $2.924,50$ \\
\hline Adjunto/Doutorado & $3.110,96$ & $3.388,02$ \\
\hline Associado/Graduação & $2.588,51$ & $2.708,47$ \\
\hline Associado/Aperfeiçoamento & $2.781,22$ & $2.905,67$ \\
\hline Associado/Especialização & $2.989,74$ & $3.145,27$ \\
\hline Associado/Mestrado & $3.335,50$ & $3.520,66$ \\
\hline Associado/Doutorado & $3.733,94$ & $4.334,73$ \\
\hline Titular/Graduação & $2.801,70$ & $2.801,70$ \\
\hline Titular/Aperfeiçoamento & $3.000,20$ & $3.000,20$ \\
\hline Titular/Especialização & $3.242,88$ & $3.242,88$ \\
\hline Titular/Mestrado & $3.723,62$ & $3.723,62$ \\
\hline Titular/Doutorado & $4.334,73$ & $4.334,73$ \\
\hline
\end{tabular}

Fonte: DGP - elaborada pelo autor. 
Tabela A.2 - Vencimento básico, piso e teto por classe e nível de formação acadêmica - 2104 em R\$.

\begin{tabular}{|c|c|c|}
\hline \multicolumn{3}{|c|}{ Docente regime de trabalho: $\mathbf{4 0}$ horas } \\
\hline Classe/Nível & Vencimento/Piso & Vencimento/Teto \\
\hline Auxiliar/Graduação & $2.764,45$ & $2.834,24$ \\
\hline Auxiliar/Aperfeiçoamento & $2.874,67$ & $2.952,33$ \\
\hline Auxiliar/Especialização & $3.017,58$ & $3.128,70$ \\
\hline Auxiliar/Mestrado & $3.594,50$ & $3.701,55$ \\
\hline Auxiliar/Doutorado & $4.699,21$ & $4.799,56$ \\
\hline Assistente/Graduação & $2.938,37$ & $3.010,32$ \\
\hline Assistente/Aperfeiçoamento & $3.065,31$ & $3.141,92$ \\
\hline Assistente/Especialização & $3.268,59$ & $3.363,46$ \\
\hline Assistente/Mestrado & $3.843,68$ & $3.929,00$ \\
\hline Assistente/Doutorado & $4.964,01$ & $5.121,77$ \\
\hline Adjunto/Graduação & $3.118,50$ & $3.392,96$ \\
\hline Adjunto/Aperfeiçoamento & $3.256,49$ & $3.539,88$ \\
\hline Adjunto/Especialização & $3.509,79$ & $3.823,06$ \\
\hline Adjunto/Mestrado & $4.060,43$ & $4.463,59$ \\
\hline Adjunto/Doutorado & $5.308,00$ & $5.843,64$ \\
\hline Associado/Graduação & $3.861,19$ & $4.004,47$ \\
\hline Associado/Aperfeiçoamento & $4.062,97$ & $4.210,32$ \\
\hline Associado/Especialização & $4.404,38$ & $4.551,42$ \\
\hline Associado/Mestrado & $5.055,87$ & $5.225,13$ \\
\hline Associado/Doutorado & $6.371,44$ & $6.599,97$ \\
\hline Titular/Graduação & $4.146,71$ & $4.146,71$ \\
\hline Titular/Aperfeiçoamento & $4.358,35$ & $4.358,35$ \\
\hline Titular/Especialização & $4.694,46$ & $4.694,46$ \\
\hline Titular/Mestrado & $5.533,93$ & $5.533,93$ \\
\hline Titular/Doutorado & $7.052,79$ & $7.052,79$ \\
\hline
\end{tabular}

Fonte: DGP - elaborado pelo autor. 
Tabela A.3 - Vencimento básico, piso e teto por classe e nível de formação acadêmica - 2104 em R\$.

\begin{tabular}{lcc}
\hline & Docente regime de trabalho: Dedicação Exclusiva $($ DE) \\
\hline Classe/Nível & Vencimento/Piso & Vencimento/Teto \\
\hline Auxiliar/Graduação & $3.804,29$ & $3.865,83$ \\
Auxiliar/Aperfeiçoamento & $4.155,78$ & $4.238,97$ \\
Auxiliar/Especialização & $4.412,51$ & $4.501,49$ \\
Auxiliar/Mestrado & $5.736,27$ & $5.881,92$ \\
Auxiliar/Doutorado & $8.344,64$ & $4.880,74$ \\
\hline Assistente/Graduação & $4.111,05$ & $4.176,95$ \\
Assistente/Aperfeiçoamento & $4.486,98$ & $4.554,90$ \\
Assistente/Especialização & $4.770,75$ & $4.888,20$ \\
Assistente/Mestrado & $6.131,30$ & $6.212,35$ \\
Assistente/Doutorado & $8.740,03$ & $8.828,62$ \\
\hline Adjunto/Graduação & $4.484,99$ & $4.704,71$ \\
Adjunto/Aperfeiçoamento & $4.886,08$ & $5.166,76$ \\
Adjunto/Especialização & $5.201,90$ & $5.508,42$ \\
Adjunto/Mestrado & $6.746,87$ & $7.205,96$ \\
Adjunto/Doutorado & $9.536,86$ & $10.373,57$ \\
\hline Associado/Graduação & $5.923,92$ & $6.144,71$ \\
Associado/Aperfeiçoamento & $6.487,70$ & $6.801,48$ \\
Associado/Especialização & $6.921,59$ & $7.251,19$ \\
Associado/Mestrado & $9.075,17$ & $9.299,81$ \\
Associado/Doutorado & $13.604,50$ & $15.059,09$ \\
\hline Titular/Graduação & $6.363,17$ & $6.363,17$ \\
Titular/Aperfeiçoamento & $7.201,29$ & $7.201,29$ \\
Titular/Especialização & $7.790,29$ & $7.790,29$ \\
Titular/Mestrado & $9.656,57$ & $9.656,57$ \\
Titular/Doutorado & $15.956,07$ & $15.956,07$ \\
\hline Fora: DGP - elaborado &
\end{tabular}

Fonte: DGP - elaborado pelo autor. 
Tabela A.4 - Vencimento básico, piso e teto, por classe e nível de escolaridade - 2104 em reais corrente.

\begin{tabular}{lllc}
\hline Classe / Nível & & Vencimento Básico / Piso & Vencimento Básico / Teto \\
\hline Ensino Básico & / A & $1.140,64$ & $2.193,64$ \\
Ensino Básico / B & $1.367,86$ & $2.630,62$ \\
Ensino Básico / C & $1.640,34$ & $3.154,66$ \\
Ensino Médio / D & $2.115,37$ & $3.923,06$ \\
Ensino Superior / E & $3.392,42$ & $6.524,20$ \\
\hline
\end{tabular}

Fonte: DGP - Elaborada pelo autor 